NBER WORKING PAPER SERIES

\title{
WHO NEEDS A FRACKING EDUCATION? THE EDUCATIONAL RESPONSE TO LOW-SKILL BIASED TECHNOLOGICAL CHANGE
}

\author{
Elizabeth U. Cascio \\ Ayushi Narayan \\ Working Paper 21359 \\ http://www.nber.org/papers/w21359 \\ NATIONAL BUREAU OF ECONOMIC RESEARCH \\ 1050 Massachusetts Avenue \\ Cambridge, MA 02138 \\ July 2015, Revised February 2019
}

We thank James Feyrer, Erin Mansur, and Bruce Sacerdote for their assistance with the drilling data and helpful discussions, Lucinda Hall for her help in mapping the shale deposits, and seminar participants at Cornell University, Michigan State University, Williams College, the Fourth SOLE/EALE Annual Meeting, and the 2018 American Economic Association Annual Meeting, especially Na'ama Shenhav, for useful comments. We also thank Eric Edmonds, Ethan Lewis, and Andrew Samwick for helpful comments on Narayan's earlier research, advised by Cascio, upon which this paper builds. The views expressed herein are those of the authors and do not necessarily reflect the views of the National Bureau of Economic Research.

NBER working papers are circulated for discussion and comment purposes. They have not been peer-reviewed or been subject to the review by the NBER Board of Directors that accompanies official NBER publications.

(C) 2015 by Elizabeth U. Cascio and Ayushi Narayan. All rights reserved. Short sections of text, not to exceed two paragraphs, may be quoted without explicit permission provided that full credit, including $\odot$ notice, is given to the source. 
Who Needs a Fracking Education? The Educational Response to Low-Skill Biased Technological Change

Elizabeth U. Cascio and Ayushi Narayan

NBER Working Paper No. 21359

July 2015, Revised February 2019

JEL No. I20,J2,J3,O33,Q33,R23

\begin{abstract}
We explore the educational response to fracking, a recent technological breakthrough in the oil and gas industry, taking advantage of the timing of its diffusion and spatial variation in shale reserves. We show that fracking has significantly increased relative demand for less-educated male labor and high school dropout rates of male teens, both overall and relative to females. Our estimates imply that, absent fracking, the teen male dropout rate would have been 1 percentage point lower over 2011-15 in the average labor market with shale reserves, implying an elasticity of school enrollment with respect to earnings below historical estimates. Fracking increased earnings more among young men than teenage boys, suggesting that educational decisions respond to improved earnings prospects, not just opportunity costs. Other explanations for our findings, like changes in school quality, migration, or demographics, receive less empirical support.
\end{abstract}

Elizabeth U. Cascio

Department of Economics

Dartmouth College

6106 Rockefeller Hall

Hanover, NH 03755

and NBER

elizabeth.u.cascio@dartmouth.edu

Ayushi Narayan

Harvard University

1805 Cambridge Street

Cambridge, MA 02138

ayushi_narayan@g.harvard.edu 


\section{Introduction}

Technological change, much of it complementary to skilled labor, has defined the U.S. economy for more than a century. Its effects have not been confined to labor markets. By increasing the return to education, skill-biased technological change (SBTC) spurred stunning growth in educational attainment through cohorts born in the mid-20 $0^{\text {th }}$ century (Goldin and Katz, 2008). In more recent generations, however, increases in the relative demand for skill have consistently outstripped increases in its relative supply, suggesting that the elasticity of educational attainment with respect to the skill premium may now be low and contributing to rising wage inequality (Katz and Murphy, 1992; Goldin and Katz, 2008). Yet, producing credible micro-level evidence on how SBTC affects educational investment decisions is difficult given the typically widespread nature of technological change.

This paper estimates the educational response to a recent technological breakthrough in a specific industry - oil and gas extraction. By pumping large quantities of fluids at high pressure down a wellbore into horizontal wells in a target rock formation, hydraulic fracturing - or "fracking" - has made it possible to extract oil and natural gas from shale plays unreachable through conventional technologies (U.S. Environmental Protection Agency, 2013). Recent research suggests that the local employment impacts of fracking have been sizable and extend beyond oil and gas extraction, expanding industries like mining, transportation, and construction that disproportionately employ less-educated men (Feyrer, Mansur, and Sacerdote, 2017). ${ }^{1}$ Additionally, labor markets that have tightened due to fracking have seen employers in other sectors cut education and experience requirements to fill positions (Modestino, Shoag, and Balance, 2017). There is also direct evidence that labor demand shocks from fracking have

\footnotetext{
${ }^{1}$ For general employment effects, see also Bartik et al. (forthcoming) and Maniloff and Mastromonaco (2017). Krupnick and Echarte (2017) provide a recent review of the broader literature.
} 
favored men without a college degree (Bartik, 2018; Kearney and Wilson, 2018). We go further, documenting that fracking has improved the labor market prospects of male high school dropouts by more than any other group. Fracking thus provides a case study in "less" skill-biased technological change, with implications for education that are the reverse of the standard SBTC story: if responsive to the skill premium, educational investments should have fallen due to fracking.

We explore the evolution of educational outcomes across areas with different shale oil and gas endowments as fracking has spread. ${ }^{2}$ Because of the identification challenges posed by the migratory response to fracking, we focus on high school enrollment and dropout decisions of teenagers, measured in both survey and administrative data (the Census/American Community Survey (ACS) and the Common Core of Data (CCD), respectively). Our empirical approach is to compare local labor markets - commuting zones $(\mathrm{CZs})$ - with different shale oil and gas reserves over time. ${ }^{3}$ We focus on 14 states with major shale plays, ${ }^{4}$ and our preferred models are demanding, removing bias from time-varying shocks to enrollment that vary across states and across CZs with different pre-fracking observables. Like Bartik et al. (forthcoming), our models also allow fracking's impacts to phase-in gradually. We assume that they begin to unfold across

\footnotetext{
${ }^{2}$ Our approach is methodologically similar to that of Michaels (2011), which estimates the long-term consequences of oil abundance in the U.S. South, including impacts on educational attainment in the resident adult population. ${ }^{3} \mathrm{CZs}$ are collections of contiguous counties (possibly crossing state boundaries) that were strongly linked on the basis of commuting patterns in the 1990s (Tolbert and Sizer, 1996). Like metropolitan areas, CZs have been used in past research to define local labor markets (e.g., Autor and Dorn, 2013; Autor, Dorn, and Hanson, 2013a, 2013b; Chetty et al., 2014), but they have the relative advantage of covering the entire United States, including rural areas. $\mathrm{CZs}$ are thus ideal for our analysis, since fracking is largely a rural phenomenon. Feyrer, Mansur, and Sacerdote (2017) also find that CZs do a good job of capturing the local economic impacts of fracking, which do not respect county boundaries.

${ }^{4}$ Shale plays are shale formations with similar geologic and geographic properties that have significant quantities of natural gas. We define major plays as those shale plays that have reserve estimates reported by Energy Information Administration. See Data Appendix.
} 
the country in 2006, but our substantive conclusions are robust to incorporating geographic variation in timing and to allowing fracking opportunities to arise nationwide at an earlier date.

We find that fracking has slowed the rate of decline in high school dropout among male teenagers since the early 2000s. Our estimates imply that, due to fracking, the dropout rate of 17 18-year-old boys (as measured in the Census/ACS) was 1.1 percentage points higher and the ratio of $11^{\text {th }}$ and $12^{\text {th }}$ grade enrollment (as measured in the CCD) to the $17-18$-year-old population 1.4 percentage points lower over 2011-15 in the average community with shale gas and/or oil reserves. This substantive conclusion is robust to how we estimate reserves and, as noted, to changes in timing the onset of fracking's diffusion. We also show in the Census/ACS that the estimates are accounted for largely by boys who have not recently migrated, suggesting that fracking has changed educational decisions among teenagers, rather than their residential choices. Controlling for changes in the demographics of teen boys and allowing for increases in compulsory schooling ages to have disparate effects in CZs with larger shale endowments also influence these findings very little. Estimates for girls are indistinguishable from zero, but we can often rule out effects as large as we find for boys, consistent with the incidence of fracking's labor market impacts.

These estimates are reduced-form, however, leaving causal mechanisms uncertain. Labor demand shocks from fracking could have encouraged boys to drop out not just by increasing the longer-term earnings prospects of male high school dropouts, but also by raising the short-term opportunity cost of staying in school. While we cannot rule out a role for increased opportunity costs, we show that fracking improved labor market outcomes significantly more for young men than teenage boys, suggesting a change in the perceived return to schooling contributed to the male dropout response. Even so, perceptions of this return based on older cohorts may differ 
from the actual return for affected cohorts, since fracking may affect that return through other channels - by reducing school quality, for instance. Though recent research has found male schooling choices to be more sensitive to school quality (Autor et al., forthcoming), we can rule out even small effects of fracking on overall per-pupil school spending and average class sizes, suggesting that male schooling choices would have to be considerably more sensitive to quality measures orthogonal to school resources to explain our findings.

These conclusions diverge from those of Weber (2014), who finds that natural gas fracking in four states has increased the share of the adult population with a high school degree and reduced the dropout share. The difference may owe to migration: fracking has generated modest, but consistent net in-migration of working-age adults (Bartik, 2018; Wilson, 2017). By focusing on a younger, less mobile population, we attempt to isolate educational decisions from residential ones, like previous studies of resource booms and busts (Black, McKinnish, and Sanders, 2005; Emery, Ferrer, and Green, 2012; Morissette, Chan, and Lu, 2015), and as noted, our survey data allow us to rule out migration as a confounder. By incorporating more states and multiple data sources, our analysis is also more comprehensive than concurrent studies of fracking's impacts on the schooling decisions of young people (e.g., Marchand and Weber, 2015; Rickman, Wang, and Winters, 2017; Zuo, Schieffer, and Buck, 2018). More states allow for consideration of the mediating effects of changes in state education policies like compulsory schooling laws. Multiple data sources also allow us to closely examine which mechanisms are driving the dropout response. ${ }^{5}$

\footnotetext{
${ }^{5}$ Exploiting school district variation in shale geology across the state of Texas and temporal variation in energy prices over the 2000s, Marchand and Weber (2015) find declines in vocational and economically disadvantaged student enrollment. Rickman, Wang, and Winters (2017) focus on the educational attainment of native-born individuals aged 18-24 using cross-state variation between three states and a synthetic control group. Zuo, Schieffer, and Buck (2018) provide a complementary analysis using different sources of fracking-related variation and focusing on aggregate high school enrollment from the CCD, without separate estimates by sex.
} 
More broadly, we add to a recent surge of papers on the educational impacts of aggregate economic shocks, which has considered settings from trade shocks in Mexico and around the world (Atkin, 2016; Blanchard and Olney, 2017), to the housing price bubble in the U.S. (Charles, Hurst, and Notowidigdo, 2018), to infrastructure and workfare programs in India (Adukia, Asher, and Novosad, 2017; Shah and Steinberg, 2017). Like these studies, we exploit localized variation in the incidence of an economic shock. To our knowledge, however, this paper is among the first to present micro-level evidence of the downstream effects of technological change on schooling decisions.

A back-of-the-envelope calculation based on our estimates yields an elasticity of male high school enrollment with respect to adult male earnings of around 0.18 , below the lower bound of the range of elasticities estimated by Black, McKinnish, and Sanders (2005) in their study of the 1970s coal boom and 1980s coal bust. We might have expected if anything a stronger response to technological change in resource extraction than to even long-lived resource price shocks. Yet, these findings are consistent with a low supply elasticity of educated labor today (Goldin and Katz, 2008), and provide some of the first credible micro-level evidence that a weak educational response to SBTC may be contributing to widening wage inequality.

\section{Background on Fracking}

\section{A. Geography and Timing}

Figure 1 plots geographic variation in fracking potential for the 17 states containing at least one $\mathrm{CZ}$ that is part of a major shale play. ${ }^{6} \mathrm{We}$ derive the reserve measure from the 2011 map of shale plays published by the Energy Information Administration (EIA) and the maximum

\footnotetext{
${ }^{6}$ We focus on all shale plays with oil reserves and/or gas reserves reported by the EIA for at least four years between 2008 and 2015. There are 17 states with at least one CZ containing a major shale play by this definition: Arkansas, Colorado, Kentucky, Louisiana, Maryland, Montana, Nebraska, New Mexico, New York, North Dakota, Ohio, Oklahoma, Pennsylvania, Texas, Virginia, West Virginia, and Wyoming.
} 
EIA-reported economically recoverable oil and gas reserves by major shale play across 2008 to 2015. ${ }^{7}$ Overlaying the shale map to CZs, we allocate oil and gas reserves to CZs based on the fraction of each play that they represent, then convert them to a common metric that captures the amount of heating energy that they contain - millions of British Thermal Units (MMBTUs).

There is considerable regional variation in reserves per capita (2000 population), with clusters of high-reserve areas in the Western, Southern, and mid-Atlantic regions. These areas lie atop different major shale plays: the Bakken (in Montana and North Dakota), the Barnett, Eagle Ford, Fayetteville, Haynesville-Bossier, and Woodford (in Louisiana, Oklahoma, and Texas), and the Marcellus (in Pennsylvania and West Virginia). However, although the reserve measure is rather blunt, constructed from just the intersection of a $\mathrm{CZ}$ with a major play and the overall play's economic potential, ${ }^{8}$ there is also variation in the magnitude of per-capita reserves across areas that are close geographically. This means we can identify the effects of fracking from within-state variation in reserves across CZs, an approach that helpfully sweeps out the shared effects of other state-level shocks, such as changes in state education policy or other aggregate economic developments. It also mitigates the influence of outliers in the reserve distribution, which are concentrated in states like North Dakota and Texas.

Our estimation sample restricts attention to the 14 states in Figure 1 where data on employment and earnings by sex are available from the year 2000 forward from the Quarterly

\footnotetext{
${ }^{7}$ Economically recoverable reserves are estimated volumes of hydrocarbon resources that analysis of geologic and engineering data demonstrates with reasonable certainty are recoverable under existing economic and operating conditions.

${ }^{8}$ We therefore don't take advantage of within-play differences in "prospectivity," which could reflect local efforts to identify economically recoverable reserves and be independently related to trends in educational attainment. See the Data Appendix for a complete description of how the reserve measure was calculated. We explore the robustness of our estimates to different ways of constructing reserves in Table 5.
} 
Workforce Indicators (QWI), our primary source on the labor market impacts of fracking. ${ }^{9} \mathrm{We}$ also trim the sample to exclude the smallest $5 \%$ and largest $10 \%$ of CZs within each state, based on population in the year 2000. ${ }^{10}$ Table 1 Panel A shows that, while the average $\mathrm{CZ}$ in this sample has substantial shale reserves, its shale oil and gas production as of 2000 was not that high. This is expected: shale gas and oil reserves have become exploitable only as horizontal drilling and fracking have spread. For our main analysis, we date the start of widespread use of fracking to 2006 - a year that predates the first frack dates of the highest-reserve plays but marks the rough beginning of the application of the technology in lower-reserve plays. ${ }^{11}$ The aggregate annual production trends shown in Figure 2 for horizontal or directional ("unconventional") wells, based on data from DrillingInfo, are consistent with shale gas and oil production taking off after $2005 .{ }^{12}$

\section{B. $\quad$ Evidence on the Spread of Fracking}

The combination of geography and time forms the core of our identification strategy: if fracking has increased the propensity of teens to drop out of school, dropout rates should have

\footnotetext{
${ }^{9}$ We lose Arkansas, Kentucky, and Wyoming due to missing QWI data for the year 2000. Schooling estimates are substantively similar when we include these states, as shown in the Appendix. Data sources are discussed below and described completely in the Data Appendix.

${ }^{10}$ The motivation for this is twofold: our outcome measures are especially noisy for the smallest CZs, and the largest CZs often include large cities that do not seem a valid counterfactual for the typical $\mathrm{CZ}$ with shale reserves. We drop a total of $57 \mathrm{CZs}$ due to this sample restriction. Our findings for schooling attainment are substantively similar if we drop the smallest $10 \%$, rather than $5 \%$, of CZs within each state, but are more sensitive to including larger cities. See Appendix.

${ }^{11}$ We prefer this approach to one taking advantage of variation in first frack dates across shale plays given the potential endogeneity of play-specific timing and the fact a lack of ACS data for 2001-2004 makes variation in timing more difficult to exploit convincingly. However, our estimates are qualitatively similar when we exploit this timing (Table 5). Bartik et al. (forthcoming) report first frack dates of 2008 for both the Marcellus play and the Haynesville-Bossier play, for shale gas, and of 2007 and 2009, respectively, for the Bakken play and the Eagle Ford play, for shale oil. Smaller plays, like Avalon Bone-Spring (oil), Fayetteville (gas), Woodford (gas), were reportedly first fracked in 2005 or 2006.

12 The data are annual aggregates of monthly well-level production data from DrillingInfo. Following prior research using these data, we classify production from horizontal and directional ("unconventional") wells as fracking, or as coming from shale. To be conservative, we classify unknown well types as vertical (or "conventional") wells. In Table 5, we assess the robustness of our findings to the choice of 2006 in various ways.
} 
increased more - or declined less, given that dropout rates were declining over this period (Murnane, 2013) - as fracking has spread, and more so in places with larger shale endowments. It is therefore useful to begin our investigation by establishing that our reserves measure and assumptions about timing predict changes in local economic activity consistent with existing estimates. Because it is important for the interpretation of the dropout findings that follow in Section III, we also document the sex and skill bias in these changes to local economic activity using data from the QWI, which aggregates administrative microdata on jobs and earnings covering 95\% of private sector workers (see Data Appendix) and has recently been used in other work to expose granularity in the local labor market impacts of fracking (Kearney and Wilson, 2018).

Figure 3 Panel A presents event-study estimates of the impacts of fracking on oil and gas production per capita (in thousands of MMBTUs), based on CZ-by-year aggregates of the DrillingInfo data underlying Figure 2. More specifically, the figure plots estimates of the $\theta_{\tau}$ 's from the following model:

$$
y_{z s t}=\sum_{\tau \neq 2005} \theta_{\tau} \text { reserves }_{z} D_{t}^{\tau}+\lambda_{s t}+\delta_{z}+\varepsilon_{z s t},
$$

where $y_{z s t}$ represents per-capita oil and gas production in $\mathrm{CZ} z$ in state $s$ in year $t$; reserves $_{z}$ is the CZ's predicted per-capita shale reserves (in MMBTUs; Figure 1); $D_{t}^{\tau}$ represents a year dummy set to one when $t=\tau$, and $\lambda_{s t}$ and $\delta_{z}$ are vectors of state-by-year and CZ fixed effects, respectively. The $\theta_{\tau}$ 's trace out what happened over time to the within-state slope that characterizes the relationship between production and reserves $_{z}$; as fracking has spread, for

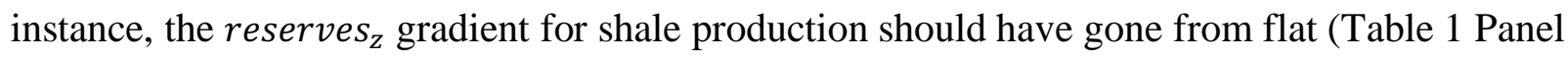
A) to upward-sloping. The capped vertical lines represent $90 \%$ confidence intervals on these estimates, with standard errors clustered on CZ. 
As expected, there is no evidence of an impact of shale reserves on conventional oil and gas production from vertical wells: the slope on reserves does not significantly change between 2005 (the year for the omitted interaction) and any subsequent (or prior) years. However, the coefficient estimates for production from horizontal wells (fracking) suggest that production picked up in higher-reserve CZs several years after 2005; the first statistically significant change in slope, relative to 2005 , actually does not occur until 2011. But the overall pattern is not surprising given the trends in Figure 2, and it is reassuring that greater growth occurs in CZs with higher shale oil and gas endowments per our reserve measure.

Wells needed to be drilled before they can produce, however, so the labor demand effects of fracking should have been felt before large production impacts. And it is arguably these employment shocks - rather than shale production per se - that are more salient for schooling choices. The black triangles in Figure 3 Panel B represent event-study estimates for the jobs-topopulation ratio for men ages 25 and over. ${ }^{13}$ The underlying data are CZ-by-year aggregates of quarterly county- and sex-level data from the QWI, for the numerator, and annual sex-specific Census-based estimates of county population from SEER (Survey, Epidemiology, and End Results Program at the National Cancer Institute), for the denominator (see Data Appendix). The event-study coefficients imply that, despite significantly lower jobs-to-population levels in 2000 (Table 1, Panel B), higher-reserve CZs did not experience different job growth for men between 2000 and 2005. Thereafter, however, higher-reserve CZs start gaining jobs for men faster than lower-reserve CZs in the same state. This phenomenon strengthens through the end of the period

\footnotetext{
${ }^{13}$ We focus on the entire population ages 25 and over because the educational breakdown of jobs and monthly earnings by sex, explored in Table 3 and Figure 4, is available only for this broad age group in the QWI. See the Data Appendix for a complete description of the QWI data. We consider impacts on jobs and earnings in narrower age bands, across all education categories, in the section on causal mechanisms (Table 7).
} 
with a distinct increase in effect size between 2010 and 2012. The female coefficients (gray diamonds) are much lower in magnitude, implying smaller impacts on female employment. Another way of measuring the labor demand shocks from fracking is to estimate its impacts on the earnings prospects. To this end, we follow Charles, Hurst, and Notowidigdo (2018) in estimating impacts on the natural log of "expected" monthly earnings, with expected monthly earnings defined as the product of the average monthly earnings of adults ages 25 and over times the jobs-to-population ratio. As shown in Figure 3 Panel C, this measure suggests more sizable labor market impacts over 2006 to 2010, but a difference between an immediate and a later post-fracking period is still noticeable.

To characterize the pattern of labor market impacts revealed by model (1) parsimoniously, and to quantify the patterns shown, we consider a slightly modified differencein-differences model, with two post-fracking periods:

$$
y_{z s t}=\theta_{1} \text { reserves }_{z} D_{t}^{06-10}+\theta_{2} \text { reserves }_{z} D_{t}^{11-15}+\lambda_{s t}+\delta_{z}+\varepsilon_{z s t},
$$

where $D_{t}^{06-10}$ and $D_{t}^{11-15}$ are dummies set to one when $t$ is in the ranges 2006-10 and 2011-15, respectively. ${ }^{14} \theta_{1}$ thus represents the average change in the within-state reserves $_{z}$ gradient between 2006-10 and 2000-05, and $\theta_{2}$ represents the change between 2011-15 and 2000-05. To validate this specification, we also test whether estimates of $\theta_{1}$ and $\theta_{2}$ are different.

Unless otherwise noted, throughout the remainder of the paper, we estimate model (2) including time-varying effects of the pre-existing (year 2000) CZ observables in Table 1 Panel D. As shown in column 2, CZs with higher per-capita shale reserves differ in some ways from

\footnotetext{
${ }^{14}$ We have also estimated deviation-from-trend models, which effectively impose separate linear fits on the eventstudy coefficients before and after 2005 . The identifying assumption is that, in the absence of fracking, any trending

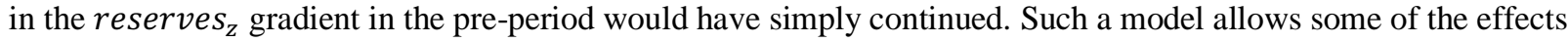
of fracking to be immediate (post-2005 reserves $s_{z}$ intercept shift) and some to accumulate over time (post-2005

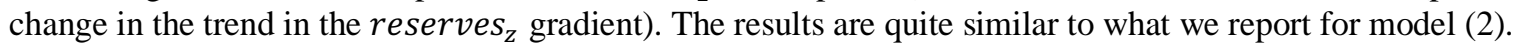


those with lower reserves in the same state: they had significantly lower median annual household incomes and black population shares in 2000, for example. ${ }^{15}$ Though the coefficients are not too large in magnitude, ${ }^{16}$ failure to allow for time-varying effects of these characteristics, in addition to time-varying effects of reserves ${ }_{z}$, could therefore bias our estimates.

The first two columns of Table 2 Panel A present estimates of model (2) for the jobs-topopulation ratio of people ages 25 and over (x100), separately by sex, including this vector of additional controls. ${ }^{17}$ Column 3 then shows estimates of the difference in the male and female coefficients. Panel B repeats this exercise for the natural log of expected monthly earnings. In each panel, the first row uses a simple linear transformation to convert $\hat{\theta}_{2}$ into a more interpretable magnitude: the implied effects of fracking over 2011-15 for the average CZ with any reserves $\left(\hat{\theta}_{2} \times \hat{\mu}_{\text {reserves|reserves }>0}\right.$, where $\hat{\mu}_{\text {reserves|reserves }>0}=42,060$ MMBTUs, from Table 1 Panel A). The average $\mathrm{CZ}$ with reserves gained more jobs for men than women due to fracking: about 43 male jobs for every 1000 adult men and about 6 female jobs for every 1000 adult women by 2011-15. It also saw substantial earnings growth: expected earnings were $10.4 \%$ higher for men, and 2.6\% higher for women, by 2011-15. These estimates are roughly in line with other nationwide studies examining the labor market effects of fracking. ${ }^{18}$ For both

\footnotetext{
${ }^{15}$ Each $\mathrm{CZ}$ is given equal weight, except in the case of outcomes constructed from public-use microdata, in which case we weight for efficiency purposes by cell size. For the purposes of the fixed effects, we assign CZs to the states in which the majority of their population resides.

16 Table 1 column 3 shows that the predicted difference in median household income in the average $\mathrm{CZ}$ with shale reserves versus without is about $\$ 886$, which represents $2.7 \%$ of the variable's mean (figure in italics) and $15.4 \%$ of its standard deviation. We arrive at similar calculations regarding magnitudes for other variables where there are statistically significant coefficients on reserves . $_{\text {. }}$

${ }^{17}$ Appendix Table A1 provides the corresponding estimates for oil and gas production, measured both in thousands of MMBTUs and in millions of 2012 dollars. Estimates of $\theta_{1}$ and $\theta_{2}$ for unconventional production are relatively less precise, consistent with Figure 3 Panel A. Effects for the conventional production measures are not statistically significant.

${ }^{18}$ For example, Bartik et al. (forthcoming) estimate an increase in employment of $3.6 \%$ to $5.4 \%$ and earnings of $4.4 \%$ to $6.9 \%$ in the top quartile of "fracking potential" counties. Extensive reviews of the relevant literature provided by Maniloff and Mastromonaco (2017) and Krupnick and Echarte (2017) find employment effects that range from $1.3 \%$ to $14.4 \%$ and earnings effects that range from $1.8 \%$ to $16.7 \%$.
} 
outcomes, there is a significant difference in effects between the immediate and later postfracking periods, and men were significantly more affected.

As evidence on whether there is indeed a skill bias to these labor demand shocks, in addition to a bias toward men, Table 3 breaks out the jobs and earnings gains by four categories of educational attainment. We estimate the sex- and education-specific CZ population by multiplying the overall adult $\mathrm{CZ}$ population by the share of adult men or women ages $25-64$ with the relevant completed education in the Census or ACS. ${ }^{19}$ For brevity, we show only implied effects by 2011-15 for the average $\mathrm{CZ}$ with any reserves, calculated as earlier described ${ }^{20}$ Figure 4 provides a graphical representation of the corresponding event-study (model (1)) estimates.

Men of all education levels have experienced job and expected earnings gains as a result of fracking (Panel A). However, gains along both dimensions have been largest among high school dropouts: by 2011-15, the average male dropout in a CZ with any reserves had a 7 percent higher chance of holding a job due to fracking - a figure marginally significantly larger than the gain for high school graduates $(p=0.063)$. In addition, male dropouts ages 25 and over in the average CZ with reserves would have expected to earn, across 2011-15, 12.7\% more than they otherwise would have. This is not significantly greater than the earnings growth expected by high school graduates $(p=0.185)$, but it is significantly greater than the expected earnings growth among men with some college or more. Among women, jobs gains were more similar across education categories, but earnings gains were also most substantial at the bottom of the distribution (Panel B).

\footnotetext{
${ }^{19}$ We estimate this time-, sex-, and education-varying population share using the 2000 Census and the 2005-2015 ACS. We linearly interpolate these shares for 2001 through 2004.

${ }^{20}$ Appendix Tables A2 and A3 show the corresponding coefficient estimates from model (2) for both outcomes along with p-values on the difference in coefficients between 2006-10 and 2011-15. We reject equality at the 0.05 significance level in all cases except for the jobs-to-population ratio for female dropouts $(p=0.055)$.
} 


\section{Fracking and High School Dropout}

We have established that our measure of shale reserves and assumptions about the timing of the spread of fracking predict changes in local economic activity consistent with existing findings. We have also added to existing understanding of these changes by exploiting more granular data: not only did places with more shale reserves experience more growth in labor demand starting around 2006 - particularly in 2011 and later - those increases in labor demand were weighted toward men, and among men, those less-educated. Male high school dropouts saw the greatest improvements in their jobs and earnings prospects.

Collectively, these findings suggest that the educational decisions of young men, including on the high school dropout margin, are likely to have been affected by fracking. Our next goal is to estimate the reduced-form effect of fracking on high school dropout by sex, using the same models that we employed in Section II; we defer further discussion of causal mechanisms to Section IV.

\section{A. Data}

We use two sources of information on dropout; neither is ideal, but they provide complementary evidence on the phenomenon of interest.

First, we construct high school dropout rates from the public-use microdata samples (PUMS) of the 2000 Census and the 2005 through 2015 ACS (Ruggles et al., 2015). These data provide person-level information on sex, age, school enrollment, and educational attainment and identify local geography down to the Public Use Microdata Area (PUMA) level. While PUMAs are not the same as CZs, they can be allocated to CZs based on the division of county population across PUMAs and the mapping between CZs and counties. As with our analysis on the spread of fracking, we choose to aggregate to the $\mathrm{CZ}$ level to capture the local economic impacts of 
fracking, which do not respect county or PUMA boundaries (Feyrer, Mansur, and Sacerdote, 2017). We focus on 17- and 18-year-olds - an age group for which dropout decisions are salient but migration for work is low - and define dropout as having not recently been enrolled in school and not having a high school degree or GED (see Data Appendix).

Though suitable for this analysis, the Census and ACS have limitations. First, small samples (5\% in the Census and 1\% in the ACS) contribute to imprecision. Second, no information on PUMA is available in the 2001 to 2004 ACS, limiting the years available to establish common outcomes trends in the pre-fracking period, which are implicit in a differencein-differences specification. Third, the dropout rates from the Census and ACS are not necessarily comparable due to differences in survey timing. ${ }^{21}$

Our second data source - the CCD - helps to address these limitations. The CCD includes annual school-district level data on high school enrollment by grade and sex. Enrollment data in the CCD are in principle consistently measured and cover all school districts in the United States. After accounting for some lapses in coverage, aggregating $11^{\text {th }}$ and $12^{\text {th }}$ grade enrollment (combined) from the district to the $\mathrm{CZ}$ level, and normalizing by estimates of the 17-18-year-old population from SEER, we have an annual series on sex-specific enrollmentto-population ratios beginning in the 1999-00 academic year (represented as 2000 to follow). The main limitation of this series is that data are missing for 2009-10 (2010). ${ }^{22}$

\footnotetext{
${ }^{21}$ The Census, officially collected on April 1, solicits school enrollment as of February 1. By contrast, the ACS is fielded throughout the year (with survey month not publicly reported) and asks about school enrollment over the past three months. Because a new school year begins typically in August or September, a higher share of the 17- and 18-year-olds surveyed in the fall - and therefore a higher share of 17- and 18-year-olds in the ACS - will be of age to be enrolled in $12^{\text {th }}$ grade or beyond. If teens sometimes make dropout decisions based on grade rather than age, and if that tendency happens to be correlated with $\operatorname{reserves}_{z}$, our estimates from the Census/ACS analysis could be biased.

${ }^{22}$ See Data Appendix for more detail on both sources.
} 


\section{B. Baseline Estimates}

Figure 5 presents event-study estimates of model (1) for the $11^{\text {th }}$ and $12^{\text {th }}$ grade enrollment-to-population ratio (Panel A) and for the high school dropout rate of 17- and 18-yearolds (Panel B). In both cases, we restrict attention to the same sample of CZs considered in Section II; the standard errors underlying the $90 \%$ confidence intervals (capped vertical lines) are clustered on CZ; and we include time-varying effects of the CZ observables in Table 1 Panel D, in an attempt to improve precision. We also weight the estimates in Panel B by cell size.

The coefficients are noisier than those in Figure 3 Panel B and Figure 4. However, the estimates are consistent with fracking weakening the attachment of teenage boys to high school. As was the case in Figures 3 and 4 for jobs-to-population ratios and expected earnings, the gradient between male dropout and reserves $_{z}$ (black triangles) shows a distinctly different trend after 2005 from the flat trend that preceded it. Starting in 2006, higher-reserve CZs begin to see larger reductions - or smaller increases - in male enrollment-to-population ratios relative to lower-reserve CZs in the same state (Panel A). For dropout, the pattern is flipped, showing relative increases in dropout in high versus low-reserve CZs in 2006 and later (Panel B). In both panels, the point estimates appear consistent with a larger impact, on average, in 2011 and later, precisely when fracking appears to start having larger labor market impacts. The event-study coefficients for female dropout rates (gray diamonds) do not display this pattern.

Table 4 presents estimates from the more restrictive difference-in-differences specification, model (2), for teen male (column 1) and female (column 2) enrollment-topopulation ratios (Panel A) and dropout rates (Panel B). Regressions in both panels include stateby-year and CZ fixed effects as well as time-varying effects of year $2000 \mathrm{CZ}$ observables, to match the figures. Considering first the estimates for boys, neither outcome variable experiences 
a statistically significant change in the reserves $z$ gradient between 2006-10 and 2000-05, though coefficients move in the direction of increased dropout. However, there is a significantly greater decrease (increase) in the enrollment-to-population ratio (dropout rate) for relatively high reserve CZs between 2011-15 and 2000-05, and the data reject equality of the difference-in-differences coefficients for 2006-10 and 2011-15. The point estimates imply that, due to fracking, male enrollment-to-population (dropout rates) in the average $\mathrm{CZ}$ with any reserves were 1.4 percentage points lower (1.12 percentage points higher) over 2011-15. Column 2 confirms that a similar phenomenon is not happening for teen girls, and column 3 shows the differences in estimated effects across sex are statistically significant.

\section{Specification Checks}

Table 5 explores the sensitivity of our estimates to a number of changes in the econometric specification. For reference, Panel A repeats the sex-specific estimates for both enrollment-to-population and dropout rates from Table 4. Columns 5 and 6 of each panel demonstrate how the changes in specification affect sex-specific estimates of the impact of fracking on the natural log of expected monthly earnings (Table 2). This is a useful benchmark, since specifications that generate weaker "first stage" impacts on the labor market should also generate weaker impacts on school enrollment, if changes in the labor market are the key mechanism linking fracking to schooling decisions. Throughout, we give predicted effects by 2011-15 in the average $\mathrm{CZ}$ with any reserves. ${ }^{23}$

To begin, we consider sensitivity to controls. In Panel B, we first drop the controls for time-varying effects of the year $2000 \mathrm{CZ}$ observables in Table 1 Panel D. The impacts on the

\footnotetext{
${ }^{23}$ Appendix Table A4, A5, and A6 show the corresponding coefficients from the specifications in Panels B, C, and D, respectively. Plots of event-study coefficients for each of these specifications are in Appendix Figures A1, A2, and $\mathrm{A} 3$.
} 
estimates are generally small and not consistent across outcomes. However, substituting year fixed effects only for the state-by-year fixed effects in our preferred model slightly raises the magnitude of the estimated impacts for boys. Such a finding may arise if fracking opportunities in a $\mathrm{CZ}$ also increased dropout propensities of boys elsewhere in the state. But an alternative explanation is that higher-reserve CZs are in states where dropout rates would have been falling less quickly over time for other reasons. Although the estimates are largely similar, state-by-year fixed effects help to ensure our estimates are not contaminated by these state-specific shocks. The final specification in Panel B provides unweighted estimates for the dropout outcome. The standard errors actually fall slightly in the unweighted specification, suggesting the potential importance of small outliers. The point estimates, however, remain basically unchanged.

Panel $\mathrm{C}$ considers different assumptions about timing. First, we assign each $\mathrm{CZ}$ with reserves the first frack year for the earliest-fracked shale play it lies atop $\left(t_{z}^{*}\right)$, with dates as reported by Bartik et al. (forthcoming). The model of interest is then:

$$
y_{z s t}=\theta \text { reserves }_{z} \text { post }_{z t}+\lambda_{s t}+\delta_{z}+\varepsilon_{z s t},
$$

where post $_{z t}=1\left[t \geq t_{z}^{*}\right]$. The intuition of the empirical approach still applies; the only change is the introduction of variation across states in when the reserves ${ }_{z}$ gradient should begin to change. For both schooling outcomes, the estimates are now smaller in magnitude for boys. However, estimated impacts on adult male earnings are as well, and implied effects of local earnings growth on schooling decisions for boys are quite similar to what we saw at baseline, particularly for the enrollment-to-population ratio. Nevertheless, we can no longer reject equality of the impacts on dropout rates across boys and girls. The next specification is a simple difference-indifferences, comparing 2011-15 to the year 2000 only, and so acknowledging that fracking occurred earlier in some places. The primary consequence is to reduce statistical power. 
Panel D explores the robustness of our conclusions to alternative predictions of local shale reserves. The first two approaches weight oil and gas reserves by price rather than energy content in the aggregate reserve prediction under extreme assumptions: using the peak ratio of oil to gas prices (from 2012) and the peak ratio of gas to oil prices (from 2003). ${ }^{24}$ We then apply the earliest available shale play reserve estimates (from 2008), combining oil and gas into common energy units as in our original measure. ${ }^{25}$ For boys, the implied effects of earnings growth on enrollment (column 1) and dropout (column 3) are weakened the most when using 2008 reserve estimates, but they are still evident, suggesting that using more recent reserves data mainly serves to improve statistical power. Dropout estimates for girls continue to remain indistinguishable from zero, and in most cases remain significantly lower in magnitude than those for boys. Overall, the implications are the same regardless of how reserves are measured: fracking appears to have lowered schooling attainment for teenage boys much more so than for girls. $^{26}$

\section{Education, Location, or Policy?}

Collectively, the specification checks above produce estimates that are substantively similar to those at baseline: the schooling decisions of teenage boys appear to have been

\footnotetext{
${ }^{24}$ In essence, we bound the relative weights placed on oil and gas when combined using prices; although there is temporal and geographic variation in energy prices, price expectations as relevant for our analysis would arguably fall between these extremes of annual industry-standard price benchmarks.

${ }^{25}$ Shale oil reserve estimates are not available until 2011, so our local per-capita reserve estimates for 2008 are imputed for oil with 2011 reserve values.

${ }^{26}$ Appendix Table A7 shows sensitivity of our schooling estimates to changes in the estimation sample. The reduced-form estimates are slightly smaller in magnitude when we include CZs from the three states with major shale plays but without QWI data for 2000, though we still reject equality of effects by 2011-15 across sex. Dropping the bottom 10\% rather than the bottom 5\% of a state's CZs (based on size) has lesser effect on the estimates than dropping the top 5\% rather than the top 10\% of a state's CZs. In the latter case, the estimated effect on male dropout shrinks (but remains significant) and we can no longer reject equality of effects with females. We think our preferred sample selection rule is justifiable given that large CZs are unlikely to provide a valid counterfactual for smaller CZs where fracking is more prevalent, and indeed, the balance tests in Table 1 column 2 look less compelling with larger CZs included.
} 
significantly more negatively affected by fracking than those of teenage girls. Before we move on to why educational choices were affected by fracking, it is useful to confirm that the estimates indeed reflect educational decisions rather than residential ones. Concerns over migration motivated our study of teenagers, but could migration still be affecting our estimates? Setting aside the question of migration, other explanations for our findings besides fracking, like heterogeneity in responses to changes in state education policies, are also possible.

Consider migration first, which we can observe in Census and ACS microdata. Because of the endogeneity of migration, we do not condition estimation on it but rather decompose the outcome variable into a dummy for being both a dropout and a recent migrant (in the past year in the ACS and in the past 5 years in the Census) and a dummy for being both a dropout and not a recent migrant; the sum of coefficients across these two outcomes is equal to the total baseline dropout effect. As shown in Table 6 Panel B, only the estimates for being both a dropout and not a recent migrant are statistically significant for boys and statistically different between boys and girls. The vast majority of the reduced-form estimate thus appears to be accounted for by educational choices rather than residential ones.

Even if not driven by migration, shifts in the demographics of the local population could be incidentally correlated with the spread of fracking and could therefore influence our estimates. In the first set of estimates in Panel C, we control for time-varying local shares of the Census and ACS 17- and 18-year-olds who are black, Hispanic, or who have recently migrated. The implied effects on dropout change little, suggesting that fracking is not strongly correlated with changes in the composition of 17- and 18-year-olds, at least on these observable dimensions. ${ }^{27}$

\footnotetext{
${ }^{27}$ We would like to include family background measures, like family income or parental education, but these variables are only available for the selected sample of 17- and 18-year-olds in the Census and ACS who still live with their parents.
} 
As a final check that our estimates reflect a response to fracking rather than to other changes in the local environment, we control for changes in the age at which states allow children to drop out of high school. Common effects of such changes are of course already captured in our state-by-year fixed effects. But suppose that dropout rates in higher-reserve areas fell relatively less in response to the increases in compulsory schooling ages that occurred over our estimation period. ${ }^{28}$ Then a dropout effect we are attributing to fracking may really be caused by heterogeneity in the impacts of state education policy. In the last rows of Table 6 , Panel C, we assess this possibility directly by including as a control the interaction between eserves $_{z}$ and a state-by-time-varying indicator for the requirement that a person be enrolled in school until age 17 or 18 . We do this both for the dropout rate of 17-18-year-olds and for the enrollment-topopulation ratio. For males, the estimates get slightly larger in magnitude, though not significantly so, suggesting that such heterogeneity either is working against us seeing an effect or is difficult to detect given the generally small changes in dropout in response to recent changes in compulsory schooling laws (Oreopoulos, 2009).

\section{Mechanisms: Theory and Evidence}

The dropout findings capture the reduced-form effects of fracking - the effects of fracking on schooling decisions working through any channel. While such estimates are independently interesting, we also care about causal mechanisms. For example, in Becker's classic (1964) model of human capital investment, candidate mechanisms for an increase in dropout rates would include more than just a reduction in the return to a high school degree;

\footnotetext{
${ }^{28}$ Over the period of interest, the only states in our estimation sample where compulsory schooling laws changed to require enrollment until age 17 or age 18 were Colorado, Maryland, Nebraska, and West Virginia. We obtained compulsory schooling ages from 2000 forward from NCES at https://nces.ed.gov/programs/digest/d15/tables/dt15_234.10.asp?current=yes, and assumed any change occurred in the earliest possible year over the relevant interval.
} 
increases in the costs of staying in high school, namely increases in the opportunity cost, matter as well. But fracking can also affect the return to a high school degree by influencing school quality, which may rise due to additional funding, or fall due to crowding. ${ }^{29}$

To formalize the discussion of channels, consider a choice between two states - high school graduation and high school dropout - among 18-year-olds. Those who choose to graduate enter the labor market one year later than those who do not. The decision point is normalized to year 0 , so that dropouts enter the labor market in year 0 , and graduates enter in year 1 ; all individuals then work through year $T$ in discrete time indexed by $t$. Individuals $i$ vary in their ability, $d_{i}$, which is uniformly distributed over [0,1]. For simplicity, assume that earnings in both states are known at the time of the decision, with $Y_{H S}(t)>Y_{n o H S}(t) \forall t$. Also assume that the indirect or psychic costs of remaining in high school until period $1, \varphi\left(d_{i}\right)$, are decreasing in ability, so that $\varphi^{\prime}<0$. Most potential dropouts are enrolled in public school, so direct costs of remaining enrolled are zero (no tuition).

Teen $i$ chooses high school graduation if the lifetime payoff from graduation exceeds that from dropout, i.e., if $V_{H S}\left(d_{i}\right)>V_{n o H S}$. With ability uniformly distributed on [0,1], the break-even ability for staying in school, $d^{*}$, is also the high school dropout rate. If psychic costs are then linearly decreasing in ability, with $\varphi\left(d_{i}\right)=\varphi \times\left(1-d_{i}\right), \varphi>0, d^{*}$ takes on the intuitive closedform expression:

$$
d^{*}=1-\frac{1}{\varphi}(\underbrace{\sum_{t=1}^{T} \frac{1}{(1+r)^{t}}\left(Y_{H S}(t)-Y_{\text {noHS }}(t)\right)}_{\text {return to high school }}-\underbrace{Y_{n o H S}(0)}_{\text {opportunity cost }}) .
$$

\footnotetext{
${ }^{29}$ Increased family incomes could be another channel through which fracking influences the return to a degree. For example, children from families whose incomes have risen due to fracking may be gaining more skills from high school than they would have otherwise. To the extent that responses would be similar for girls and boys, they would not help to explain the gap in estimated effects by sex, which is our focal point here.
} 
Thus, the dropout rate is a decreasing function of the return to high school - or earnings prospects of dropouts over their working lives - and an increasing function of the opportunity cost of staying in school.

How does this map to the evidence that we've presented thus far? We've shown that the teen male dropout rate has risen and the return to education among adult men has fallen by more over time in areas with more shale reserves. Evidence of the same phenomena for females is much weaker, suggesting that the reduction in the return is the key causal pathway for our findings. But an increase in the opportunity cost of school enrollment for boys could also be contributing to our estimates. This would especially be the case if boys were present-biased (Cadena and Keys, 2015; Lavecchia, Lu, and Oreopoulos, 2016) and fracking increased earnings of teenage boys. The standard human capital model of course assumes that that they would be forward looking, which might not be realistic.

In an attempt to disentangle the relevance of the opportunity cost and returns to education channels, Table 7 considers the jobs-to-population ratio (Panel A) and natural log of expected monthly earnings (Panel B) for various narrow age groups and separately by sex, calculated from QWI data and population estimates as earlier described. ${ }^{30}$ For each outcome, we provide the year 2000 mean (column 1), difference-in-differences estimates from model (2) with additional controls (columns 2 to 3), the p-value on equality of the two coefficient estimates between year groups (column 4), sexes (for 2011-15, column 5), and age groups (for 2011-15, column 6), and the implied effect of fracking by 2011-15 for the average CZ with any reserves (column 7). Though fracking led only to a small increase in the likelihood of 14-18-year-old boys having

\footnotetext{
${ }^{30}$ Unfortunately, information on jobs and earnings by educational attainment and sex is not available over narrow age ranges considered in the table. See Appendix Figure A5 for event-study representations of the effects for these outcomes.
} 
jobs (Panel A), it substantially increased the wages and/or hours of those with jobs (Panel B). Those estimates are nevertheless significantly smaller than those observed for only slightly older males, ages 19-24 and 25-34, whose experiences on the job market are arguably particularly salient for prospective dropouts in forming expectations of the future.

We of course cannot rule out that teenagers are misinformed, over-reacting to a misplaced notion that well-paying jobs are immediately available to them that are not. But the estimates are also consistent with changes in the return to education playing a role in the dropout decision of boys. Nevertheless, changes in the return to education among adult men may not represent the changes in the expected return across the lifecycle for the cohorts of interest. The fracking boom could have reduced school quality, for example, lowering the skill (and future productivity) gains associated obtaining a high school degree.

Table 8 considers whether school quality has declined as a result of fracking, potentially lowering the return to schooling independently of labor market developments. We would have liked to measure school quality with some measure of school output, like test scores, but available test score data are not geographically disaggregated enough or do not span enough years to apply our empirical approach. ${ }^{31}$ Instead, we consider class size and per-pupil school spending and revenues, using CZ aggregates of annual data from the CCD and the Census of Governments and Annual Surveys of State and Local Government Finances, respectively.

\footnotetext{
31 The National Assessment of Educational Progress (NAEP) spans the period of interest, but reports data only for states and selected large school districts. With passage of the No Child Left Behind Act, states were required to test children in grades 3 through 8 in math and reading and publicly report the test results starting in 2002-03.

Unfortunately, the tests and reporting practices differ across states, so comprehensive estimates are unavailable for our study period.
} 
The first three rows of the table show that there was no effect of fracking on average class size, overall per-pupil spending, or overall per-pupil revenue. ${ }^{32}$ Given the standard errors, we can rule out small contributions of changes in school resources to our schooling estimates. ${ }^{33}$ Fracking did affect the composition of revenues, though, consistent with expectations. In line with fracking increasing property values (Bartik et al. forthcoming), fracking appears to have increased local (property-tax based) revenues per student enrolled in public schools. ${ }^{34}$ However, this positive effect on local revenues has been offset by negative revenue effects at the federal and state levels. ${ }^{35}$

While speculative, these auxiliary findings suggest that labor market developments associated with fracking are important to our school enrollment findings, and that teenage boys have based their decisions on more than just opportunity costs. Incorporating all causal pathways, our estimates yield an elasticity of high school enrollment with respect to adult

\footnotetext{
${ }^{32}$ See Appendix Figure A6 for the corresponding event-study estimates. The revenue and spending results are in line with the null effects obtained in other national-scale analysis (Bartik et al., forthcoming) but by construction are unable to capture the heterogeneous effects uncovered in regional analyses (Marchand and Weber, 2015; Newell and Raimi, 2015; Ratledge and Zachary, 2017; Weber, Burnett, and Xiarchos, 2016, Zuo, Schieffer, and Buck, 2018). Our class size results obtained at the national level also cannot produce the heterogeneity documented in regional analyses (Marchand and Weber, 2015; Ratledge and Zachary, 2017).

${ }^{33}$ For example, the upper bound on the $95 \%$ confidence interval for the average class size effect of fracking in a CZ with any reserves is less than a one student increase. As a point of comparison, Dynarski, Hyman, and Schanzenbach (2013) find that being randomly assigned to attend a small class in kindergarten (with 13 to 17 students) instead of a regular-sized class (with 22 to 25 students) - so having 5 to 12 fewer students in the same class - increased the probability of attending college by 2.7 percentage points, with an effect size for males 1.6 percentage points higher than that for females. The implied effect of an additional student on the male-female difference in college attendance is thus about 0.2 percentage point $(1.6 / 8.5$, where 8.5 is the average class size increase). If we adopted the same 0.2 percentage point implied effect of an additional student for high school dropout, we would be able to account for less than $20 \%$ of the increase in the male-female gap in dropout rates. ${ }^{34}$ Not all studies find positive effects of fracking on property values. Muehlenbachs, Spiller, and Timmins (2015) find large negative impacts on nearby groundwater-dependent house prices, though at a broader geographic scale, they find positive impacts that diminish over time. Gopalakrishnan and Klaiber (2013) also find negative impacts on property values.

${ }^{35}$ State governments often redistribute local tax revenue across school districts in an effort to narrow spending differences between more and less property-wealthy districts. Relatedly, the federal government's primary grants program (Title I) is distributed on the basis of child poverty. If fracking has reduced child poverty rates, any educational impacts for local students may have eventually been offset by reductions in Title I funds.
} 
earnings of $0.18 .^{36}$ This elasticity estimate is on the lower end of the range of elasticities that Black, McKinnish, and Sanders (2005) estimate by exploiting earnings variation from the coal boom and bust of the 1970s and 1980s, which suggest that school enrollment falls by $2.2 \%$ to $7.2 \%$ for every $10 \%$ increase in earnings. The difference in truly comparable elasticities between the two studies would, moreover, arguably be larger: the variation in Black, McKinnish, and Sanders (2005) arises from long-lived, but ultimately transitory, price-shocks, biasing downward their elasticity estimate as would be comparable to our setting of permanent, technological change. The effect size for young men in our study is thus small by historical standards.

\section{Conclusion}

Over the past decade, the widespread diffusion of horizontal drilling and fracking has fueled a structural transformation of local economies across the United States - from Pennsylvania to North Dakota - increasing local incomes and helping to set the U.S. on a path toward energy independence. Using high-frequency outcomes data and taking advantage of geographic and temporal variation in fracking, we have demonstrated that this structural transformation has had the additional consequence of slowing reductions in high school dropout rates among teenagers, particularly the young males whose longer-term labor market prospects it has more greatly affected. Though we cannot completely rule out other causal pathways, such as an increased opportunity cost, we marshal additional evidence to support the conclusion that perceptions of a reduced longer-term return to a high school degree for men were an important causal mechanism. For example, fracking did not appreciably increase jobs for teenagers.

\footnotetext{
${ }^{36}$ We calculate this elasticity by comparing the 1.43 percentage point decrease in the teen male enrollment-topopulation ratio from our baseline specification - which amounts to roughly a $1.9 \%$ decline given the baseline ratio (Table 1 Panel C) - to a $10.4 \%$ earnings gain from fracking for adult males (Table 3).
} 
Fracking also appears to have changed school resources too little for changes in school quality to be an important factor in our findings.

Do these findings provide cause for concern? As we describe, the decision to drop out of school could well be a rational one in the face of increases in later-life job opportunities for dropouts. Nevertheless, some students could be making mistakes in dropping out. There are also social benefits from completing high school that are ignored in private dropout decisions (e.g., Lochner and Moretti, 2004; Dee, 2004; Milligan, Moretti, and Oreopolous, 2004). Fracking may thus be generating sub-optimally low levels of education among some individuals who would already likely be relatively low-skilled, with possible implications for future productivity and the social safety net. Whether the human capital of a generation of young men has been permanently affected is an open question, one that cannot be readily answered with our data and research $\operatorname{design}^{37}$

Second, and more broadly, we present new evidence on the relationship between technology and educational attainment. With fracking, we have a technology that complements low-skilled labor and one whose use is geographically constrained in a way that allows for credible identification of its impacts on educational attainment. We find evidence of reductions in educational attainment at the bottom of the skill distribution, and that longer-term declines in the return to education could be an important contributing factor. In addition, converting our point estimates to an elasticity and comparing our findings directly with earlier work, we find our estimated effect sizes to be consistent with a low supply elasticity of educated labor today (Goldin and Katz, 2008).

\footnotetext{
${ }^{37}$ Although those students who drop out may re-enroll later in their lives (Emery, Ferrer, and Green (2012) do find some evidence for such re-enrollment in British Columbia), we cannot investigate this possibility with Census data.
} 
Altogether, our study suggests a smaller response in educational attainment to skillbiased labor demand shocks today than estimated in earlier decades and supports the view that SBTC has contributed to wage inequality. Even so, the effects of technological change on education may be heterogeneous across the skill distribution. Future understanding of this relationship would therefore benefit from exploration of other episodes of localized technological change, particularly ones favoring the highly skilled. 


\section{References}

Adukia, Anjali, Sam Asher, and Paul Novosad. 2017. "Educational Investment Responses to Economic Opportunity: Evidence from Indian Road Construction." Working paper.

Atkin, David. 2016. "Endogenous Skill Acquisition and Export Manufacturing in Mexico." American Economic Review 106(8): 2046-2085.

Autor, David H. and David Dorn. 2013. "The Growth of Low-Skill Service Jobs and the Polarization of the US Labor Market." American Economic Review 103(5): 1553-1597.

Autor, David H., David Dorn, and Gordon H. Hanson. 2013a. "The Geography of Trade and Technology Shocks in the United States." American Economic Review, Papers \& Proceedings 103(3): 220-225.

---. 2013b. "The China Syndrome: Local Labor Market Effects of Import Competition in the United States." American Economic Review 103(6): 2121-2168.

Autor, David, David Figlio, Krzysztof Karbownik, Jeffrey Roth, and Melanie Wasserman. Forthcoming. "Family Disadvantage and the Gender Gap in Behavioral and Educational Outcomes." American Economic Journal: Applied Economics.

Bartik, Alexander W. 2018. "Worker Adjustment to Changes in Labor Demand: Evidence from Longitudinal Census Data." Job Market Paper.

Bartik, Alexander W., Janet Currie, Michael Greenstone, and Christopher R. Knittel. Forthcoming. "The Local Economic and Welfare Consequences of Hydraulic Fracturing." American Economic Journal: Applied Economics.

Becker, Gary. 1964. Human Capital: A Theoretical and Empirical Analysis with Special Reference to Education. New York: Columbia University Press.

Black, Dan A., Terra G. McKinnish, and Seth G. Sanders. 2005. "Tight Labor Markets and the Demand for Education: Evidence from the Coal Boom and Bust." Industrial and Labor Relations Review 59(1): 3-16.

Blanchard, Emily and William W. Olney. 2017. "Globalization and Human Capital Investment: Export Composition Drives Educational Attainment.” Journal of International Economics 106: $165-183$.

Cadena, Brian C. and Benjamin J. Keys. 2015. "Human Capital and the Lifetime Costs of Impatience.” American Economic Journal: Economic Policy 7(3): 126-153.

Charles, Kerwin Kofi, Erik Hurst, and Matthew J. Notowidigdo. 2018. "Housing Booms and Busts, Labor Market Opportunities, and College Attendance." American Economic Review 108(10): 2947-2994.

Chetty, Raj, Nathaniel Hendren, Patrick Kline, and Emmanuel Saez. 2014. "Where is the Land of 
Opportunity? The Geography of Intergenerational Mobility in the United States." Quarterly Journal of Economics 129(4): 1553-1623.

Dee, Thomas. 2004. “Are There Civic Returns to Education?” Journal of Public Economics 88(910): $1697-1720$.

Dynarski, Susan, Joshua Hyman, and Diane Whitmore Schanzenbach. 2013. "Experimental Evidence on the Effect of Childhood Investments on Postsecondary Attainment and Degree Completion." Journal of Policy Analysis and Management 32(4): 692-717.

Emery, J.C. Herbert, Ana Ferrer, and David Green. 2012. "Long-Term Consequences of Natural Resource Booms for Human Capital Accumulation." Industrial and Labor Relations Review 65(3): 708-734.

Feyrer, James, Erin T. Mansur, and Bruce Sacerdote. 2017. "Geographic Dispersion of Economic Shocks: Evidence from the Fracking Revolution." American Economic Review 107(4): 1313-1334.

Goldin, Claudia and Lawrence Katz. 2008. The Race Between Education and Technology. Cambridge: Harvard University Press.

Gopalakrishnan, Sathya and H. Allen Klaiber. 2013. "Is the Shale Energy Boom a Bust for Nearby Residents? Evidence from Housing Values in Pennsylvania." American Journal of Agricultural Economics 96 (1): 43-66.

Kearney, Melissa and Riley Wilson. 2018. "Male Earnings, Marriageable Men, and Nonmarital Fertility: Evidence from the Fracking Boom.” Review of Economics and Statistics 100(4): 678-690.

Krupnick, Alan J. and Isabel Echarte. 2017. "Economic Impacts of Unconventional Oil and Gas Development." RFF Report.

Lavecchia, Adam M., Heidi Liu, and Philip Oreopoulos. 2016. "Behavioral Economics of Education: Progress and Possibilities." Handbook of Education Economics 5: 1-74.

Lochner, Lance and Enrico Moretti. 2004. "The Effect of Education on Crime: Evidence from Prison Inmates, Arrests, and Self-Reports.” American Economic Review 94(1): 155-189.

Maniloff, Peter and Ralph Mastromonaco. 2017. "The Local Economic Impacts of Hydraulic Fracturing and Determinants of Dutch Disease." Resource and Energy Economics 49: 6285.

Marchand, Joseph and Jeremy Weber. 2015. "The Labor Market and School Finance Effects of the Texas Shale Boom on Teacher Quality and Student Achievement." Working Paper.

Michaels, Guy. 2011. "The Long-Term Consequences of Resource-Based Specialization." The Economic Journal 121(551): 31-57. 
Milligan, Kevin, Enrico Moretti, and Philip Oreopolous. 2004. "Does Education Improve Citizenship? Evidence from the U.S. and the U.K." Journal of Public Economics 88(9-10): 1667-1695.

Modestino, Alicia S., Daniel Shoag, and Joshua Balance. 2016. "Downskilling: Changes in Employer Skill Requirements over the Business Cycle.” Labour Economics 41: 333-347.

Morissette, René, Ping Ching Winnie Chan, and Yuqian Lu. 2015. "Wages, Youth Employment, and School Enrollment: Recent Evidence from Increases in World Oil Prices." Journal of Human Resources 50(1): 222-253.

Muehlenbachs, Lucija, Elisheba Spiller, and Christopher Timmins. 2015. "The Housing Market Impacts of Shale Gas Development." American Economic Review 105(12): 3633-3659.

Murnane, Richard J. 2013. "U.S. High School Graduation Rates: Patterns and Explanations." Journal of Economic Literature 51(2): 370-422.

Newell, Richard G. and Daniel Raimi. 2015. "Shale Public Finance: Local Government Revenues and Costs Associated with Oil and Gas Development." NBER Working Paper 21542.

Oreopoulos, Philip. 2009. "Would More Compulsory Schooling Help Disadvantaged Youth? Evidence from Recent Changes to School Leaving Laws." Chapter 3 in The Problems of Disadvantaged Youth: An Economic Perspective edited by Jonathan Gruber. University of Chicago Press.

Ratledge, Nathan and Laura Zachary. 2017. "Impacts of Unconventional Oil and Gas Booms on Public Education: A Mixed-Methods Analysis of Six Producing States.” RFF Report.

Rickman, Dan S., Hongbo Wang, John V. Winters. 2017. "Is Shale Development Drilling Holes in the Human Capital Pipeline?" Energy Economics 62: 283-290.

Ruggles, Steven, Katie Genadek, Ronald Goeken, Josiah Grover, and Matthew Sobek. Integrated Public Use Microdata Series: Version 6.0 [dataset]. Minneapolis: University of Minnesota, 2015.

Shah, Manisha and Bryce Millett Steinberg. 2017. "Workfare and Human Capital Investment: Evidence from India.” Working Paper.

Tolbert, Charles M. and Molly Sizer. 1996. "U.S. Commuting Zones and Labor Market Areas: A 1990 Update." Economic Research Service Staff Paper 9614.

U.S. Environmental Protection Agency. 2013. "Natural gas extraction: Hydraulic fracturing." US EPA. Retrieved February 3, 2014, from http://www2.epa.gov/hydraulicfracturing.

Weber, Jeremy G. 2014. "A Decade of Natural Gas Development: The Makings of a Resource Curse?" Resource and Energy Economics 37: 168-183.

Weber, Jeremy G., J. Wesley Burnett, and Irene M. Xiarchos. 2016. "Broadening Benefits from 
Natural Resource Extraction: Housing Values and Taxation of Natural Gas Wells as Property." Journal of Policy Analysis and Management 35(3): 587-614.

Wilson, Riley. 2017. "Moving to Economic Opportunity: The Migration Response to the Fracking Boom." Working Paper.

Zuo, Na, Jack Schieffer, and Steven Buck. 2018. "The Effect of the Oil and Gas Boom on Schooling Decisions in the U.S." Resource and Energy Economics 55: 1-23. 
Figure 1 -

Predicted Per-Capita Shale Oil and Gas Reserves by Commuting Zone in States Overlapping with Major Shale Plays (Thousands of MMBTUs per Person)

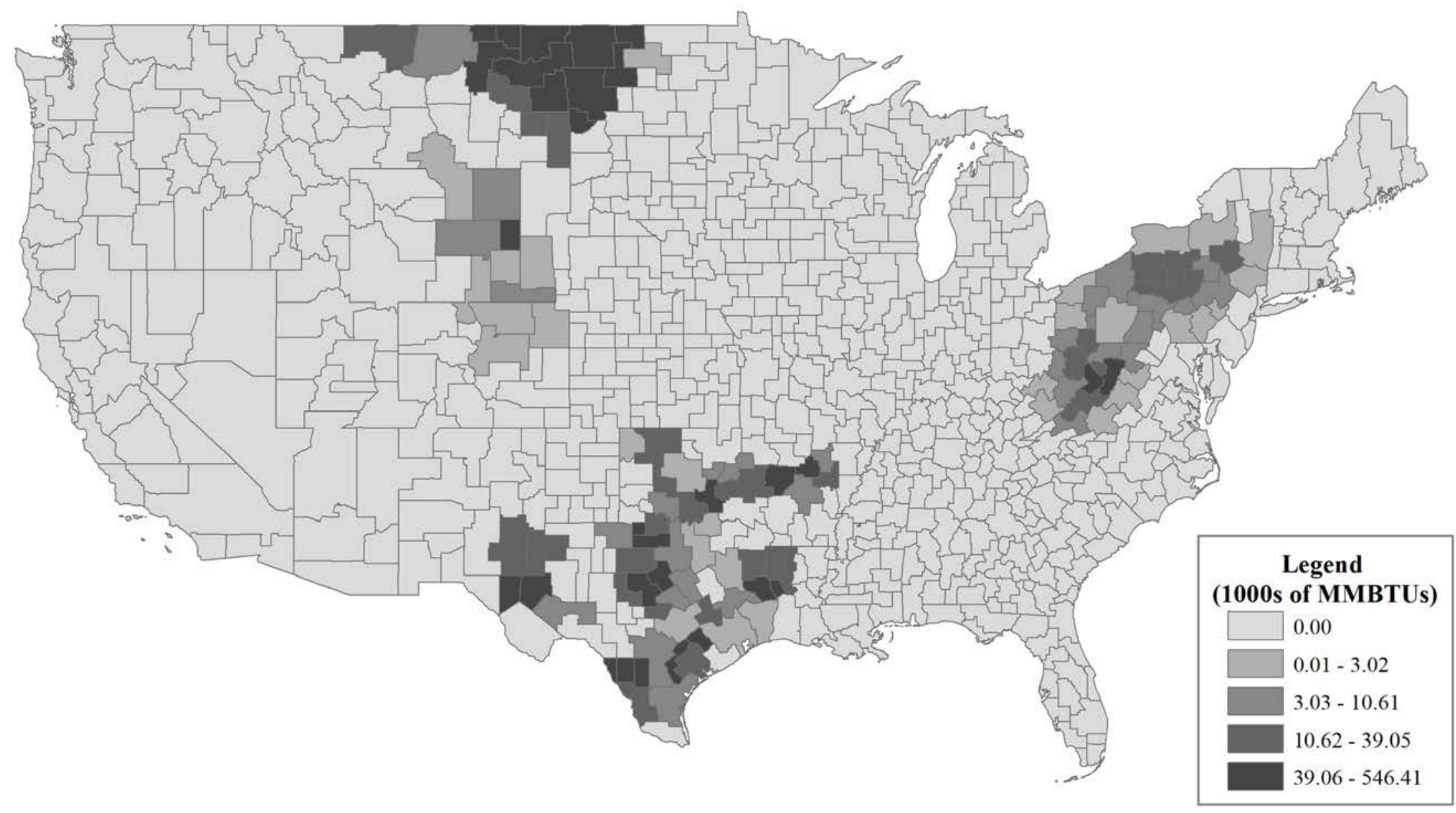

Notes: Figure gives estimated shale oil and gas reserves divided by 2000 population for commuting zones (1990 definition) in 17 states where any CZ lies atop a major shale play. Estimates of shale oil and gas reserves were derived by overlaying recent (2011) EIA maps of shale plays to commuting zones, separately for oil and gas, and allocating maximum EIA estimates of play reserves to commuting zones based on the fraction of each play that they contain. See Data Appendix. 
Figure 2 -

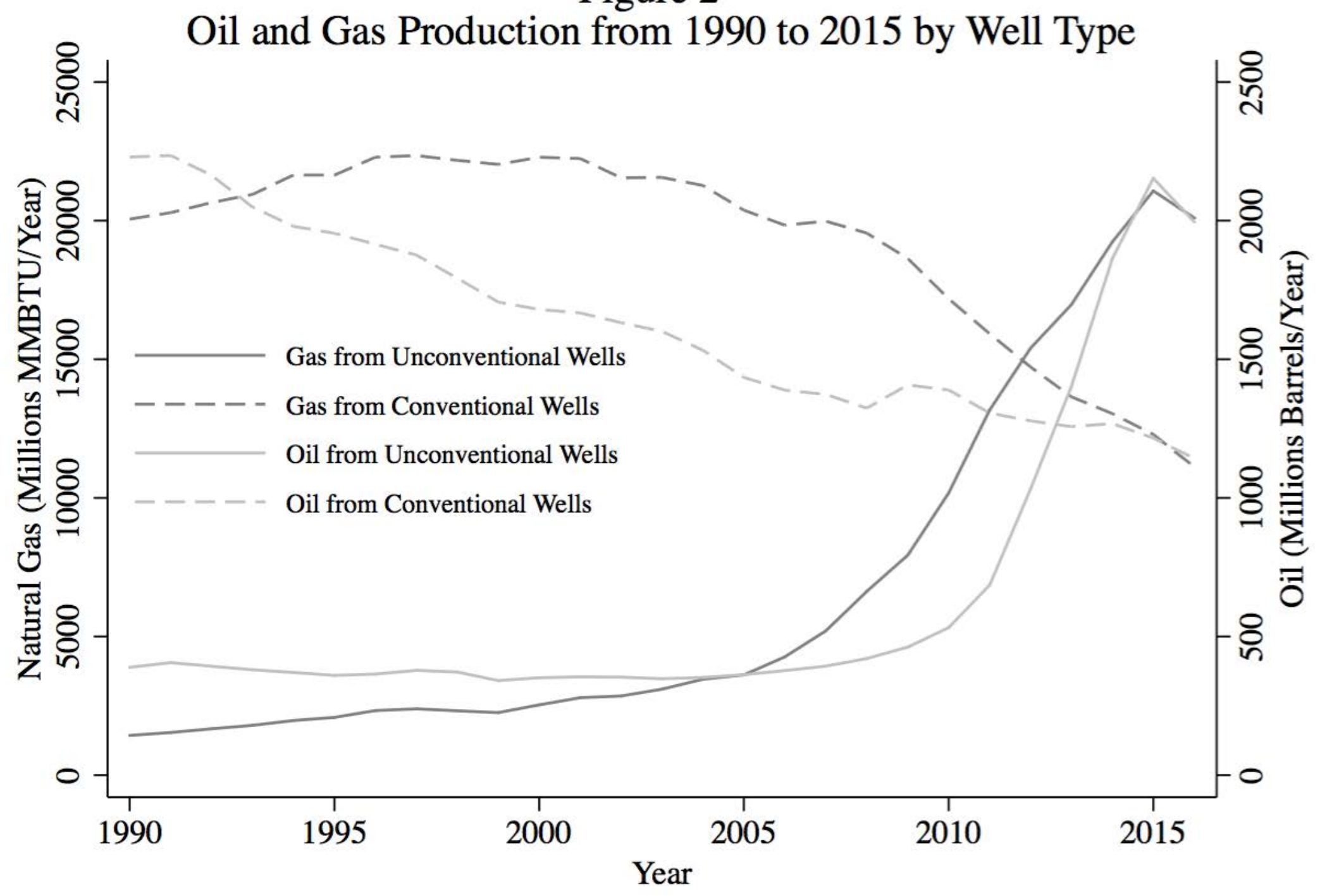

Notes: Data from DrillingInfo.com. Unconventional production is defined as production from horizontal and directional wells. Conventional production is defined as production from vertical and unknown wells. Sample consists of all 48 contiguous states. See Data Appendix. 


\section{Figure 3 -}

\section{Impacts of Fracking on Oil and Gas Production and the Local Labor Market}
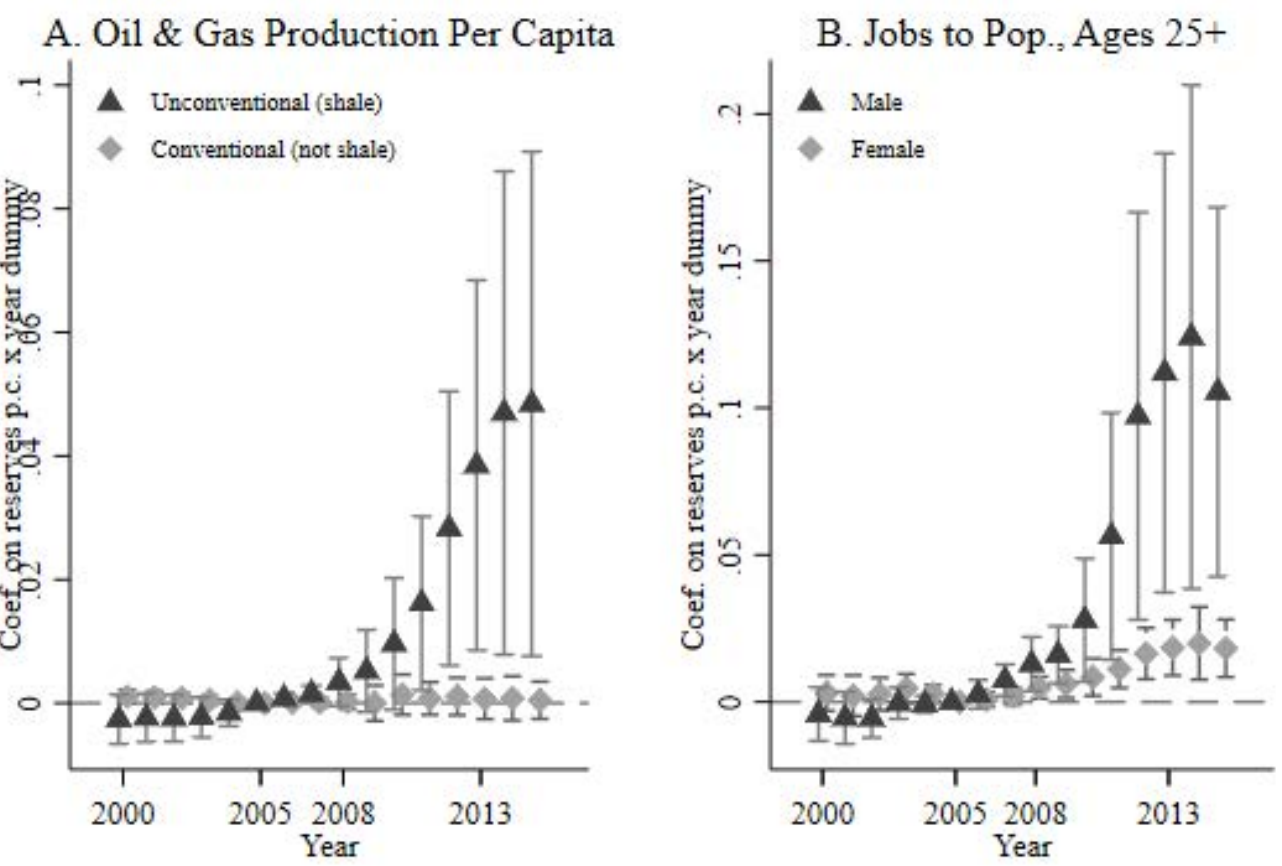

C. $\ln ($ Exp. Earnings), Ages $25+$

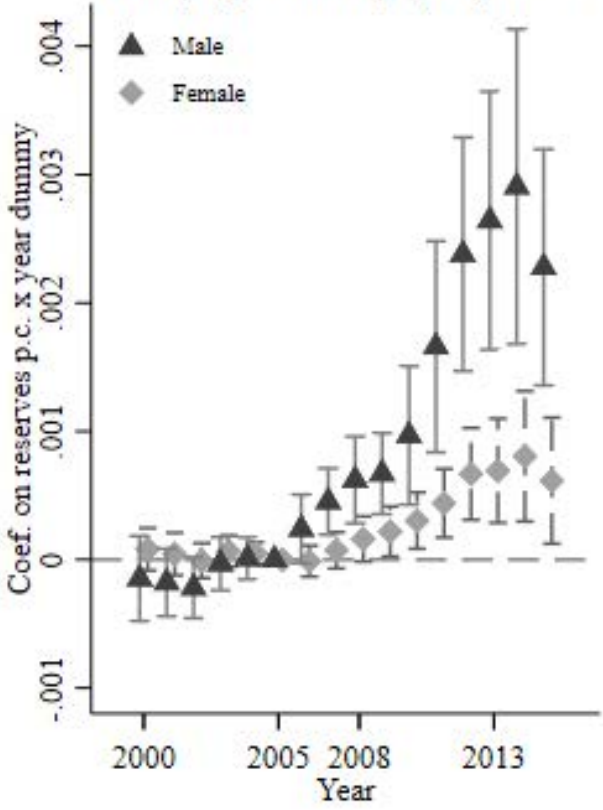

Notes: Graphs plot coefficients on interactions between year dummies and predicted shale oil and gas reserves per capita (measured in 1000s of MMBTUs and normalizing by year $2000 \mathrm{CZ}$ population) (omitting the interaction with the 2005 dummy for identification) from regressions that also include stateby-year fixed effects and commuting zone fixed effects. Each commuting zone is given equal weight in the estimation, and inference is robust to heteroskedasticity and error correlation within commuting zones over time. Capped vertical lines represent 90 percent confidence intervals on the coefficient estimates. Data are from DrillingInfo (Panel A) and the Quarterly Workforce Indicators (Panels B and C) and span 2000-2015; see Data Appendix. Sample is limited to $202 \mathrm{CZs}$ in the 14 analysis states. 


\section{Figure 4 -}

\section{The Effect of Fracking on Adult Male Jobs and Expected Earnings, by Educational Attainment}
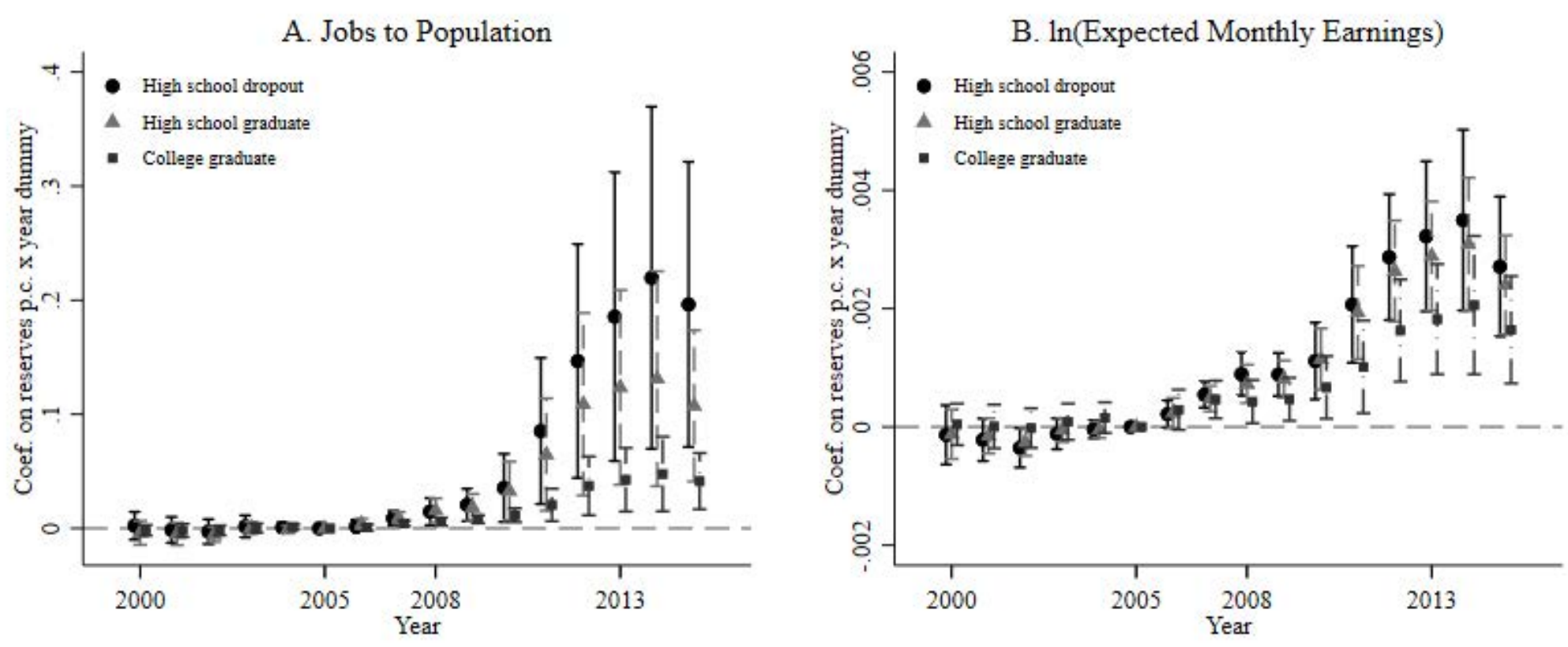

Notes: Graphs plot coefficients on interactions between year dummies and predicted shale oil and gas reserves per capita (measured in 1000s of MMBTUs and normalizing by year $2000 \mathrm{CZ}$ population) (omitting the interaction with the 2005 dummy for identification) from regressions that also include stateby-year fixed effects and commuting zone fixed effects. Each commuting zone is given equal weight in the estimation, and inference is robust to heteroskedasticity and error correlation within commuting zones over time. Capped vertical lines represent 90 percent confidence intervals on the coefficient estimates. Data are from the Quarterly Workforce Indicators (Panel B) and span 2000-2015; see Data Appendix. Sample is limited to 202 CZs in the 14 analysis states. 


\section{Figure 5 - \\ The Effect of Fracking on High School Enrollment \& Dropout}
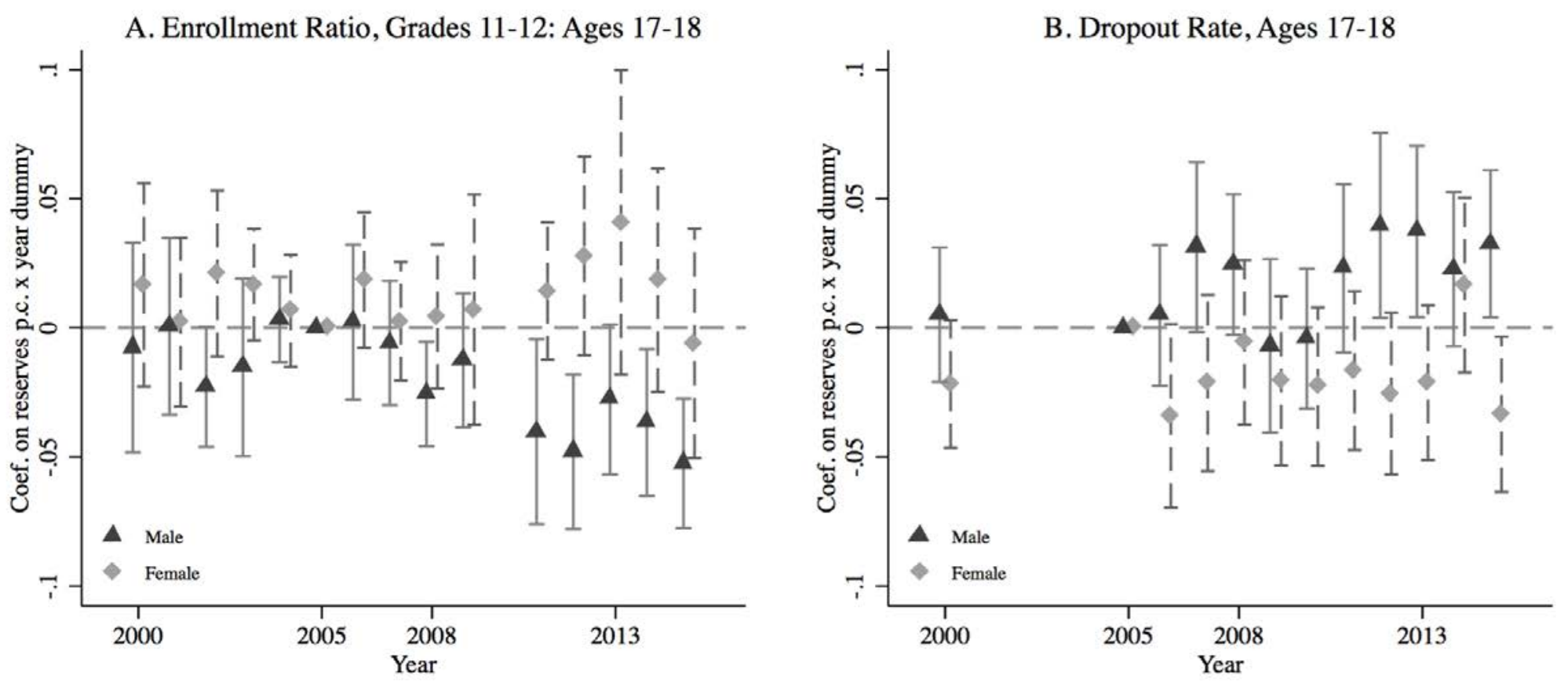

Notes: Graph plots coefficients on interactions between year dummies and predicted shale oil and gas reserves per capita (measured in 1000s of MMBTUs and normalizing by year 2000 population) from regressions that also include state-by-year fixed effects, commuting zone fixed effects, and interactions between year dummies and each of the year $2000 \mathrm{CZ}$ characteristics summarized in Table 1 Panel D. Inference is robust to heteroskedasticity and error correlation within commuting zones over time. In Panel B, regressions are weighted by the number of Census or ACS respondents used to generate the commuting zone-by-year mean dropout rates. Capped vertical lines represent 90 percent confidence intervals on the coefficient estimates. Data in Panel A are from the Common Core of Data from 1999-00 to 2014-15, and enrollment ratio is defined as the ratio of 11th and 12th grade enrollment to the 17-18year-old population. Data in Panel B are from the 2000 Census and the 2005-2015 ACS PUMS, and dropout is defined as being not currently enrolled and without a high school degree. See Data Appendix. Sample is limited to $200 \mathrm{CZs}$ (Panel A) and $202 \mathrm{CZs}$ (Panel B) in the 14 analysis states. 
Table 1 -

Year 2000 Commuting Zone Characteristics and their Association with the Presence and Intensity of Shale Oil and Gas Reserves

\begin{tabular}{|c|c|c|c|}
\hline & $\begin{array}{c}\text { Mean (sd) } \\
(1)\end{array}$ & $\begin{array}{c}\text { Coef }(\mathrm{se}) \text { on } \\
\text { reserves * } \\
(2)\end{array}$ & $\begin{array}{c}\text { Coef } \mathrm{x} \text { mean } \\
\text { res } \mid \text { res }>0 \\
(\% \text { of mean }) \\
(3)\end{array}$ \\
\hline & \multicolumn{3}{|c|}{ A. Oil and Gas Industry Characteristics } \\
\hline Shale oil \& gas reserves per capita (reserves)* & $\begin{array}{c}18.53 \\
(52.34)\end{array}$ & - & - \\
\hline reserves $\mid$ reserves $>0$ & $\begin{array}{l}42.06 \\
(72.50)\end{array}$ & - & - \\
\hline Shale oil \& gas production per capita* & $\begin{array}{c}0.231 \\
(0.890)\end{array}$ & $\begin{array}{l}-0.0002 \\
(0.0008)\end{array}$ & $\begin{array}{c}-0.0084 \\
(-3.6)\end{array}$ \\
\hline \multirow[t]{2}{*}{ Conventional oil \& gas production per capita* } & $\begin{array}{c}0.961 \\
(3.160)\end{array}$ & $\begin{array}{c}0.0005 \\
(0.0020)\end{array}$ & $\begin{array}{c}0.0210 \\
(2.2)\end{array}$ \\
\hline & \multicolumn{3}{|c|}{ B. Employment Characteristics (x100) } \\
\hline Jobs to population, male ages $25+$ & $\begin{array}{c}55.8 \\
(11.4)\end{array}$ & $\begin{array}{c}-0.0385 \\
(0.0120)\end{array}$ & $\begin{array}{l}-1.62 \\
(-2.9)\end{array}$ \\
\hline Jobs to population, female ages $25+$ & $\begin{array}{l}49.5 \\
(8.1)\end{array}$ & $\begin{array}{l}-0.0217 \\
(0.0074)\end{array}$ & $\begin{array}{l}-0.91 \\
(-1.8)\end{array}$ \\
\hline $\ln ($ expected monthly earnings, male ages $25+$ ) & $\begin{array}{l}7.8 \\
(0.3)\end{array}$ & $\begin{array}{l}-0.0017 \\
(0.0005)\end{array}$ & -0.07 \\
\hline \multirow[t]{2}{*}{$\ln ($ expected monthly earnings, female ages $25+)$} & $\begin{array}{l}7.1 \\
(0.3)\end{array}$ & $\begin{array}{l}-0.0009 \\
(0.0003)\end{array}$ & -0.04 \\
\hline & \multicolumn{3}{|c|}{ C. Educational Characteristics (x100) } \\
\hline Enrollment to population, male $11+12: 17+18$ & $\begin{array}{c}75.4 \\
(11.7)\end{array}$ & $\begin{array}{c}0.0089 \\
(0.0209)\end{array}$ & $\begin{array}{r}0.37 \\
(0.5)\end{array}$ \\
\hline Enrollment to population, female $11+12: 17+18$ & $\begin{array}{c}80.4 \\
(12.8)\end{array}$ & $\begin{array}{l}-0.0023 \\
(0.0214)\end{array}$ & $\begin{array}{l}-0.10 \\
(-0.1)\end{array}$ \\
\hline High school dropout, male ages 17-18 (\%) & $\begin{array}{l}10.45 \\
(3.42)\end{array}$ & $\begin{array}{l}-0.0062 \\
(0.0097)\end{array}$ & $\begin{array}{l}-0.261 \\
(-2.5)\end{array}$ \\
\hline High school dropout, female ages 17-18 (\%) & $\begin{array}{c}8.22 \\
(2.94)\end{array}$ & $\begin{array}{l}-0.0086 \\
(0.0071)\end{array}$ & $\begin{array}{l}-0.362 \\
(-4.4)\end{array}$ \\
\hline
\end{tabular}




\section{Table 1 (cont'd) - \\ Baseline Commuting Zone Characteristics and their Association with the Presence and Intensity of Shale Oil and Gas Reserves}

\begin{tabular}{|c|c|c|c|}
\hline & $\begin{array}{c}\text { Mean }(\mathrm{sd}) \\
(1)\end{array}$ & $\begin{array}{c}\text { Coef }(\mathrm{se}) \text { on } \\
\text { reserves * } \\
(2)\end{array}$ & $\begin{array}{c}\text { Coef } \mathrm{x} \text { mean } \\
\text { res } \mid \text { res }>0 \\
(\% \text { of mean }) \\
(3)\end{array}$ \\
\hline & \multicolumn{3}{|c|}{ D. Other CZ Characteristics } \\
\hline Black population share $(\%)$ & $\begin{array}{c}5.23 \\
(7.61)\end{array}$ & $\begin{array}{l}-0.0081 \\
(0.0045)\end{array}$ & $\begin{array}{c}-0.341 \\
(-6.5)\end{array}$ \\
\hline Hispanic population share $(\%)$ & $\begin{array}{c}12.80 \\
(19.09)\end{array}$ & $\begin{array}{c}0.0598 \\
(0.0352)\end{array}$ & $\begin{array}{l}2.515 \\
(19.6)\end{array}$ \\
\hline Unemployment rate $(\%)$ & $\begin{array}{c}3.50 \\
(1.27)\end{array}$ & $\begin{array}{c}0.0032 \\
(0.0035)\end{array}$ & $\begin{array}{l}0.135 \\
(3.8)\end{array}$ \\
\hline Child poverty rate $(\%)$ & $\begin{array}{r}19.00 \\
(7.33)\end{array}$ & $\begin{array}{c}0.0274 \\
(0.0161)\end{array}$ & $\begin{array}{l}1.153 \\
(6.1)\end{array}$ \\
\hline Median annual household income (\$2012) & $\begin{array}{l}32,318 \\
(5,744)\end{array}$ & $\begin{array}{r}-21.0541 \\
(6.8168)\end{array}$ & $\begin{array}{l}-886 \\
(-2.7)\end{array}$ \\
\hline Child disability rate (\%) & $\begin{array}{c}7.63 \\
(1.44)\end{array}$ & $\begin{array}{l}-0.0047 \\
(0.0017)\end{array}$ & $\begin{array}{l}-0.198 \\
(-2.6)\end{array}$ \\
\hline Single parent population share $(\%)$ & $\begin{array}{r}11.24 \\
(2.56)\end{array}$ & $\begin{array}{c}0.0053 \\
(0.0064)\end{array}$ & $\begin{array}{l}0.223 \\
(2.0)\end{array}$ \\
\hline English-speaking only share (\%) & $\begin{array}{c}86.35 \\
(15.84)\end{array}$ & $\begin{array}{l}-0.0490 \\
(0.0324)\end{array}$ & $\begin{array}{l}-2.061 \\
(-2.4)\end{array}$ \\
\hline Population density & $\begin{array}{c}99 \\
(177)\end{array}$ & $\begin{array}{l}-0.1467 \\
(0.0494)\end{array}$ & $\begin{array}{c}-6.2 \\
(-6.2)\end{array}$ \\
\hline N (Commuting Zones) & 202 & 202 & 202 \\
\hline
\end{tabular}

Notes: Underlying sample consists of the $202 \mathrm{CZs}$ in the 14 of the lower 48 states with any major shale gas or oil play (17 states), with available data from the Quarterly Workforce Indicators (QWI) for 2000-2015, and between the 5th and 90th percentile of size (based on average population of 17-18-year-olds over 2000-2005) for their state (202 of $259 \mathrm{CZs}$ for all variables except the enrollment-to-population ratio, where there are $200 \mathrm{CZs}$ ). The unit of observation is CZ-year (Panels A and D) or CZ-year-sex (Panels B and C). Data were drawn from DrillingInfo (Panel A oil and gas production), the QWI (Panel B jobs numbers), the Common Core of Data (Panel C enrollment numbers), the 2000 Census PUMS (Panel C dropout rates), and 2000 Census county-level tabulations (Panel D and the population figures for the jobs and enrollment to population ratios). Column 2 regressions include state fixed effects, and standard errors are heteroskedasticity-robust. * Measured in 1000s of MMBTUs. 
Table 2 -

The Effect of Shale Oil and Gas Reserves and

the Introduction of Fracking on the Jobs to Population Ratio, by Sex

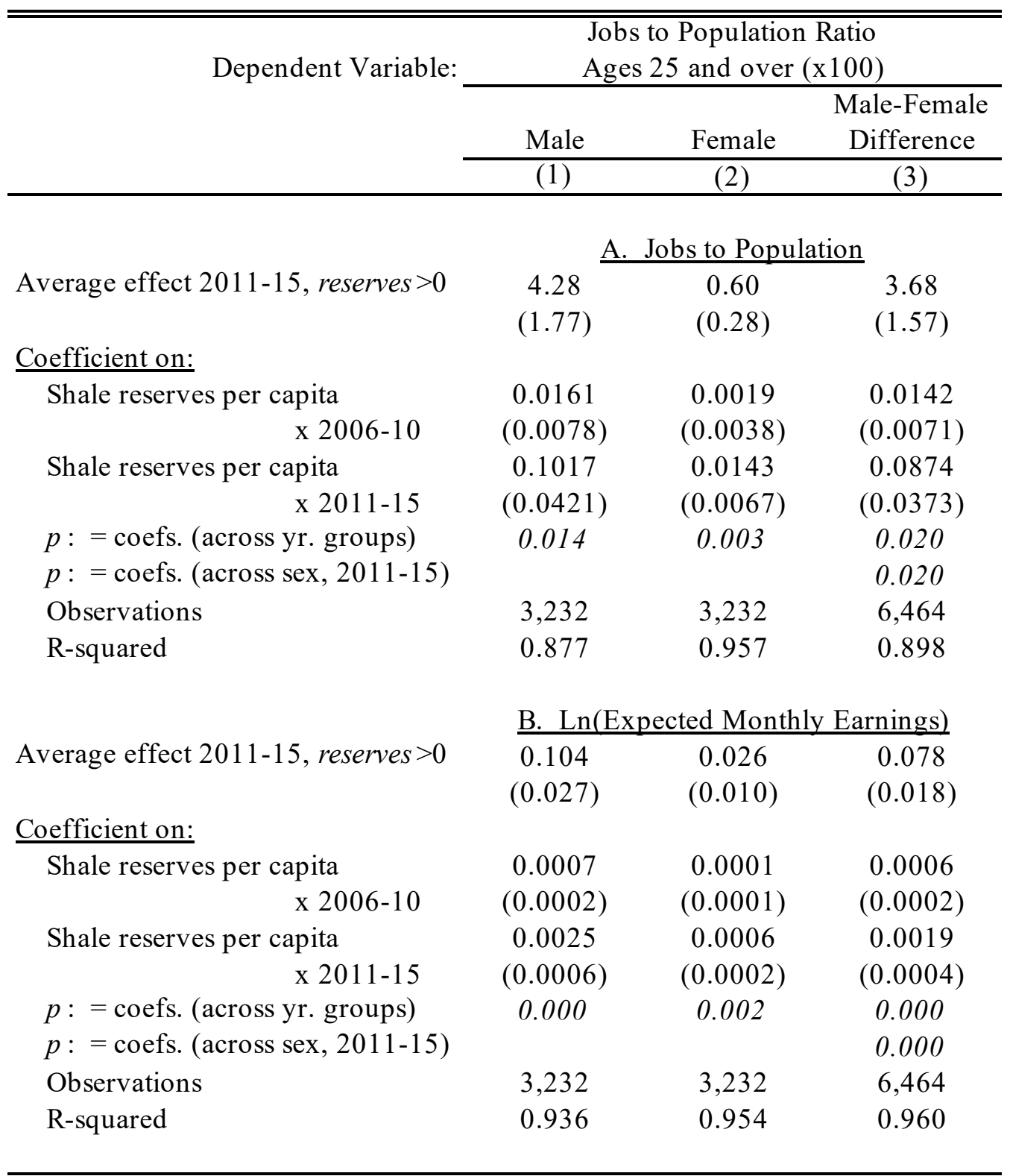

Notes: Underlying sample consists of the $202 \mathrm{CZs}$ in the 14 of the lower 48 states with any major shale gas or oil play (17 states), with available data from the QWI for 2000-2015, and between the 5th and 90th percentile of size (based on average population of 17-18-year-olds over 2000-2005) for their state $(202$ of $259 \mathrm{CZs})$. The unit of observation is CZ-year-sex. Data on jobs and monthly earnings for individuals ages 25 and over are from the 2000-2015 QWI and correspond to unweighted averages of beginning of quarter figures reported throughout the year, and data on the population ages 25 and over are from the Surveillance, Epidemiology, and End Results (SEER) program. Expected monthly earnings multiply reported monthly earnings by the jobs-to-population ratio. All regressions include state-by-year fixed effects, CZ fixed effects, and time-varying effects of each of the $2000 \mathrm{Census} \mathrm{CZ}$ characteristics listed in Table 1 Panel D. Regressions in column 3 also include interactions between these variables and a dummy for male; coefficients on the interactions with the male dummy are given in the table. Standard errors (in parentheses) are clustered on CZ. 
Table 3 -

The Effect of Shale Oil and Gas Reserves and the Introduction of Fracking on Jobs to Population and Expected Monthly Earnings, by Sex and Educational Attainment

\begin{tabular}{|c|c|c|c|c|c|}
\hline \multirow[b]{3}{*}{ Dependent variable: } & \multirow[b]{2}{*}{ Overall } & \multicolumn{4}{|c|}{ "Average effect 2011-15, reserves $>0$} \\
\hline & & $\begin{array}{c}\text { High School } \\
\text { Dropouts }\end{array}$ & $\begin{array}{c}\text { High School } \\
\text { Graduates }\end{array}$ & $\begin{array}{c}\text { College } \\
\text { Attendees }\end{array}$ & $\begin{array}{c}\text { College } \\
\text { Graduates }\end{array}$ \\
\hline & $(1)$ & $(2)$ & $(3)$ & $(4)$ & $(5)$ \\
\hline & \multicolumn{5}{|c|}{ A. $\operatorname{Men}(\mathrm{N}=3,232)$} \\
\hline Jobs to Population (x100) & $\begin{array}{c}4.28 \\
(1.77)\end{array}$ & $\begin{array}{c}7.01 \\
(2.93)\end{array}$ & $\begin{array}{c}4.61 \\
(1.98)\end{array}$ & $\begin{array}{c}6.06 \\
(2.48)\end{array}$ & $\begin{array}{l}1.62 \\
(0.67)\end{array}$ \\
\hline$p:=\operatorname{coefs}(\mathrm{v}$. dropout $)$ & & & 0.063 & 0.357 & 0.021 \\
\hline $\ln ($ Expected monthly earnings) & $\begin{array}{c}0.104 \\
(0.027)\end{array}$ & $\begin{array}{c}0.127 \\
(0.034)\end{array}$ & $\begin{array}{c}0.113 \\
(0.025)\end{array}$ & $\begin{array}{c}0.106 \\
(0.025)\end{array}$ & $\begin{array}{c}0.067 \\
(0.024)\end{array}$ \\
\hline \multirow[t]{2}{*}{$p:=\operatorname{coefs}(\mathrm{v}$. dropout $)$} & & & 0.185 & 0.060 & 0.000 \\
\hline & \multicolumn{5}{|c|}{ B. Women $(\mathrm{N}=3,232)$} \\
\hline Jobs to Population (x 100) & $\begin{array}{c}0.60 \\
(0.28)\end{array}$ & $\begin{array}{c}0.61 \\
(0.75)\end{array}$ & $\begin{array}{c}0.55 \\
(0.29)\end{array}$ & $\begin{array}{c}1.33 \\
(0.34)\end{array}$ & $\begin{array}{c}0.15 \\
(0.18)\end{array}$ \\
\hline$p:=\operatorname{coefs}(\mathrm{v}$. dropout $)$ & & & 0.910 & 0.220 & 0.520 \\
\hline $\ln ($ Expected monthly earnings) & $\begin{array}{c}0.026 \\
(0.010)\end{array}$ & $\begin{array}{c}0.051 \\
(0.019)\end{array}$ & $\begin{array}{c}0.031 \\
(0.012)\end{array}$ & $\begin{array}{c}0.029 \\
(0.009)\end{array}$ & $\begin{array}{c}0.009 \\
(0.009)\end{array}$ \\
\hline \multirow[t]{2}{*}{$p:=\operatorname{coefs}(\mathrm{v}$. dropout $)$} & & & 0.041 & 0.075 & 0.003 \\
\hline & \multicolumn{5}{|c|}{ C. Male-Female Difference $(\mathrm{N}=6,464)$} \\
\hline Jobs to Population (x100) & $\begin{array}{c}3.68 \\
(1.57)\end{array}$ & $\begin{array}{c}6.40 \\
(2.80)\end{array}$ & $\begin{array}{c}4.06 \\
(1.77)\end{array}$ & $\begin{array}{c}4.73 \\
(2.24)\end{array}$ & $\begin{array}{c}1.47 \\
(0.54)\end{array}$ \\
\hline$p:=\operatorname{coefs}(\mathrm{v}$. dropout $)$ & & & 0.131 & 0.227 & 0.040 \\
\hline $\ln ($ Expected monthly earnings) & $\begin{array}{c}0.078 \\
(0.018)\end{array}$ & $\begin{array}{c}0.076 \\
(0.024)\end{array}$ & $\begin{array}{c}0.083 \\
(0.016)\end{array}$ & $\begin{array}{c}0.076 \\
(0.017)\end{array}$ & $\begin{array}{c}0.058 \\
(0.017)\end{array}$ \\
\hline$p:=\operatorname{coefs}(\mathrm{v}$. dropout $)$ & & & 0.531 & 0.948 & 0.198 \\
\hline
\end{tabular}

Notes: Underlying sample consists of the $202 \mathrm{CZs}$ in the 14 of the lower 48 states with any major shale gas or oil play ( 17 states), with available data from the QWI for 2000-2015, and between the 5th and 90th percentile of size (based on average population of 17-18-year-olds over 2000-2005) for their state ( 202 of $259 \mathrm{CZs}$ ). The unit of observation is CZ-year-sex. Data on jobs and monthly earnings for individuals ages 25 and over are from the 2000-2015 QWI and correspond to unweighted averages of beginning of quarter figures reported throughout the year; data on the population ages 25 and over are from SEER; and estimates of education shares in the poulation a $25-64$ are from the Census and ACS. Expected monthly earnings multiply rep are from SER, and estint monthy en All regressions include state-by-year and CZ fixed effects and time-varying affects of the CZ -inte given equal weight in the estimation. Standard errors clustered on $C Z$ are in parentheses. 
Table 4 -

The Effect of Shale Oil and Gas Reserves and the Introduction of Fracking on 11th and 12th Grade Enrollment and High School Dropout Rates of 17- and 18-Year-Olds

\begin{tabular}{|c|c|c|c|}
\hline & $\frac{\text { Male }}{(1)}$ & $\frac{\text { Female }}{(2)}$ & $\begin{array}{l}\text { Male-Female } \\
\text { Difference } \\
(3)\end{array}$ \\
\hline & \multicolumn{3}{|c|}{ A. Enrollment Ratio, 11th \& 12th: Ages 17-18 } \\
\hline Average effect $2011-15$, reserves $>0$ & $\begin{array}{l}-1.43 \\
(0.63)\end{array}$ & $\begin{array}{c}0.36 \\
(0.81)\end{array}$ & $\begin{array}{l}-1.79 \\
(1.09)\end{array}$ \\
\hline \multicolumn{4}{|l|}{ Coefficient on: } \\
\hline $\begin{array}{l}\text { Shale reserves per capita } \\
\qquad \times \text { 2006-10 }\end{array}$ & $\begin{array}{l}-0.0035 \\
(0.0163)\end{array}$ & $\begin{array}{l}-0.0024 \\
(0.0166)\end{array}$ & $\begin{array}{l}-0.0010 \\
(0.0122)\end{array}$ \\
\hline $\begin{array}{l}\text { Shale reserves per capita } \\
\qquad \text { x 2011-15 }\end{array}$ & $\begin{array}{l}-0.0340 \\
(0.0151)\end{array}$ & $\begin{array}{c}0.0085 \\
(0.0192)\end{array}$ & $\begin{array}{l}-0.0425 \\
(0.0259)\end{array}$ \\
\hline $\begin{array}{l}p:=\text { coefs. }(\text { across yr. groups) } \\
p:=\text { coefs }(\text { across sex }, 2011-15)\end{array}$ & 0.07 & 0.39 & $\begin{array}{l}0.08 \\
0.10\end{array}$ \\
\hline $\begin{array}{l}\text { Observations } \\
\text { R-squared }\end{array}$ & $\begin{array}{l}3,000 \\
0.764\end{array}$ & $\begin{array}{l}3,000 \\
0.777\end{array}$ & $\begin{array}{l}6,000 \\
0.785\end{array}$ \\
\hline Average effect $2011-15$, reserves $>0$ & $\begin{array}{c}1.12 \\
(0.36)\end{array}$ & $\begin{array}{c}0.12 \\
(0.32)\end{array}$ & $\begin{array}{l}1.00 \\
(0.45)\end{array}$ \\
\hline \multicolumn{4}{|l|}{ Coefficient on: } \\
\hline $\begin{array}{l}\text { Shale reserves per capita } \\
\qquad \times \text { 2006-10 }\end{array}$ & $\begin{array}{c}0.0054 \\
(0.0082)\end{array}$ & $\begin{array}{l}-0.0022 \\
(0.0072)\end{array}$ & $\begin{array}{c}0.0076 \\
(0.0098)\end{array}$ \\
\hline $\begin{array}{l}\text { Shale reserves per capita } \\
\qquad \text { x 2011-15 }\end{array}$ & $\begin{array}{c}0.0267 \\
(0.0086)\end{array}$ & $\begin{array}{c}0.0030 \\
(0.0075)\end{array}$ & $\begin{array}{c}0.0238 \\
(0.0107)\end{array}$ \\
\hline $\begin{array}{l}p:=\text { coefs. }(\text { across yr. groups) } \\
p:=\text { coefs }(\text { across sex }, 2011-15)\end{array}$ & 0.01 & 0.50 & $\begin{array}{l}0.13 \\
0.03\end{array}$ \\
\hline Observations & 2,424 & 2,424 & 4,848 \\
\hline R-squared & 0.492 & 0.437 & 0.484 \\
\hline
\end{tabular}

Notes: Underlying sample consists of the $202 \mathrm{CZs}$ in the 14 of the lower 48 states with any major shale gas or oil play (17 states), with available data from the QWI for 2000-2015, and between the 5th and 90th percentile of size (based on average population of 17-18-year-olds over 2000-2005) for their state (202 out of $259 \mathrm{CZs}$ for the dropout rate and 200 of $259 \mathrm{CZs}$ for the enrollment-to-population ratio). The unit of observation is CZ-year-sex. Enrollment data in Panel A are from the 1999-00 to 2014-15 Common Core of Data (missing 2009-10); enrol lment figures are divided by SEER-based estimates of the CZ's 17- and 18-year-old population. Dropout data are from the 2000 Census PUMS and the 2005 through 2015 ACS PUMS. All regressions include state-by-year and CZ fixed effects, as well as time-varying effects of the 2000 Census CZ characteristics listed in Table 1 Panel D. Regressions in column 3 also include interactions between these variables and a dummy for male; coefficients on the interactions with the male dummy are given in the table. Panel $\mathrm{B}$ regressions are weighted by the number of Census or ACS respondents used to generate the CZ-year-sex mean dropout rates. Standard errors (in parentheses) are clustered on CZ. 
Table 5 -

Sensitivity of the Estimates for Dropout, Enrollment, and Earnings to Choice of Specification

\begin{tabular}{|c|c|c|c|c|c|c|}
\hline \multirow{4}{*}{ Dependent variable: } & \multicolumn{6}{|c|}{ Average effect in 2011-15, reserves $>0$} \\
\hline & \multicolumn{2}{|c|}{$\begin{array}{c}\text { Enrollment ratio, } \\
\text { Gr } 11-12: \text { Ages } 17-18\end{array}$} & \multicolumn{2}{|c|}{ Dropout, Ages 17-18 } & \multicolumn{2}{|c|}{$\begin{array}{c}\ln (\text { Expected Earnings }) \\
\text { Ages } 25+\end{array}$} \\
\hline & Male & Female & Male & Female & Male & Female \\
\hline & $(1)$ & $(2)$ & $(3)$ & (4) & (5) & $(6)$ \\
\hline & \multicolumn{6}{|c|}{ A. Baseline Model } \\
\hline Preferred specification & $\begin{array}{l}-1.43 \\
(0.63)\end{array}$ & $\begin{array}{c}0.36 \\
(0.81)\end{array}$ & $\begin{array}{l}1.12 \\
(0.36)\end{array}$ & $\begin{array}{c}0.12 \\
(0.32)\end{array}$ & $\begin{array}{c}0.104 \\
(0.027)\end{array}$ & $\begin{array}{c}0.026 \\
(0.010)\end{array}$ \\
\hline \multirow[t]{2}{*}{$p:=$ coefs $($ across sex, $2011-15)$} & \multicolumn{2}{|c|}{0.10} & \multicolumn{2}{|c|}{0.03} & \multicolumn{2}{|c|}{0.000} \\
\hline & \multicolumn{6}{|c|}{ B. Dropping Controls and Changing Weighting } \\
\hline No time-varying effects of $\mathrm{CZ}$ observables & $\begin{array}{l}-1.25 \\
(0.63)\end{array}$ & $\begin{array}{l}0.37 \\
(0.62)\end{array}$ & $\begin{array}{c}1.13 \\
(0.43)\end{array}$ & $\begin{array}{c}0.35 \\
(0.37)\end{array}$ & $\begin{array}{c}0.109 \\
(0.024)\end{array}$ & $\begin{array}{c}0.030 \\
(0.009)\end{array}$ \\
\hline$p:=$ coefs. $($ across sex, $2011-15)$ & \multicolumn{2}{|c|}{0.15} & \multicolumn{2}{|c|}{0.10} & \multicolumn{2}{|c|}{0.000} \\
\hline Year fixed effects & $\begin{array}{l}-1.49 \\
(0.62)\end{array}$ & $\begin{array}{c}0.01 \\
(0.80)\end{array}$ & $\begin{array}{c}1.47 \\
(0.40)\end{array}$ & $\begin{array}{c}0.57 \\
(0.32)\end{array}$ & $\begin{array}{c}0.117 \\
(0.031)\end{array}$ & $\begin{array}{c}0.032 \\
(0.013)\end{array}$ \\
\hline$p:=$ coefs. $($ across sex, $2011-15)$ & \multicolumn{2}{|c|}{0.19} & \multicolumn{2}{|c|}{0.03} & \multicolumn{2}{|c|}{0.000} \\
\hline \multirow[t]{3}{*}{ Unweighted (changes dropout only) } & $\begin{array}{l}-1.43 \\
(0.63)\end{array}$ & $\begin{array}{c}0.36 \\
(0.81)\end{array}$ & $\begin{array}{c}1.03 \\
(0.23)\end{array}$ & $\begin{array}{l}-0.06 \\
(0.22)\end{array}$ & $\begin{array}{c}0.104 \\
(0.027)\end{array}$ & $\begin{array}{c}0.026 \\
(0.010)\end{array}$ \\
\hline & \multicolumn{2}{|c|}{0.10} & \multicolumn{2}{|c|}{0.00} & \multicolumn{2}{|c|}{0.000} \\
\hline & \multicolumn{6}{|c|}{ C. Variation in Timing } \\
\hline Use first frack date for largest play in state & $\begin{array}{l}-1.00 \\
(0.46)\end{array}$ & $\begin{array}{c}0.22 \\
(0.68)\end{array}$ & $\begin{array}{c}0.68 \\
(0.30)\end{array}$ & $\begin{array}{c}0.44 \\
(0.29)\end{array}$ & $\begin{array}{c}0.075 \\
(0.020)\end{array}$ & $\begin{array}{c}0.019 \\
(0.008)\end{array}$ \\
\hline$p:=$ coefs.$($ across sex, post-fracking) & \multicolumn{2}{|c|}{0.16} & \multicolumn{2}{|c|}{0.49} & \multicolumn{2}{|c|}{0.000} \\
\hline Long difference: 2000 v. 2011-15 & $\begin{array}{l}-1.41 \\
(1.11)\end{array}$ & $\begin{array}{c}0.10 \\
(0.67)\end{array}$ & $\begin{array}{l}1.04 \\
(0.41)\end{array}$ & $\begin{array}{c}0.24 \\
(0.35)\end{array}$ & $\begin{array}{c}0.105 \\
(0.028)\end{array}$ & $\begin{array}{c}0.025 \\
(0.011)\end{array}$ \\
\hline$p:=$ coefs. $($ across sex, $2011-15)$ & \multicolumn{2}{|c|}{0.17} & \multicolumn{2}{|c|}{0.12} & \multicolumn{2}{|c|}{0.000} \\
\hline
\end{tabular}


Table 5 (cont'd) -

Sensitivity of the Estimates for Dropout, Enrollment, and Earnings to Choice of Specification

\begin{tabular}{|c|c|c|c|c|c|c|}
\hline \multirow{4}{*}{ Dependent variable: } & \multicolumn{6}{|c|}{ Average effect in 2011-15, reserves $>0$} \\
\hline & \multicolumn{2}{|c|}{$\begin{array}{c}\text { Enrollment ratio, } \\
\text { Gr 11-12: Ages 17-18 }\end{array}$} & \multicolumn{2}{|c|}{ Dropout, Ages 17-18 } & \multicolumn{2}{|c|}{$\begin{array}{c}\ln (\text { Expected Earnings }) \\
\text { Ages } 25+\end{array}$} \\
\hline & Male & Female & Male & Female & Male & Female \\
\hline & $(1)$ & $(2)$ & $(3)$ & $(4)$ & $(5)$ & $(6)$ \\
\hline & \multicolumn{6}{|c|}{ D. Alternative Reserve Estimates } \\
\hline $\begin{array}{l}\text { Value of reserves using } 2003 \text { prices } \\
\text { (max gas price:oil price, } 1000 \text { s of } \$ 2012 \text { ) }\end{array}$ & $\begin{array}{l}-1.40 \\
(0.62)\end{array}$ & $\begin{array}{c}0.37 \\
(0.80)\end{array}$ & $\begin{array}{c}1.12 \\
(0.36)\end{array}$ & $\begin{array}{c}0.14 \\
(0.31)\end{array}$ & $\begin{array}{c}0.102 \\
(0.027)\end{array}$ & $\begin{array}{c}0.025 \\
(0.011)\end{array}$ \\
\hline$p:=$ coefs. $($ across sex, 2011-15) & \multicolumn{2}{|c|}{0.10} & \multicolumn{2}{|c|}{0.03} & \multicolumn{2}{|c|}{0.000} \\
\hline $\begin{array}{l}\text { Value of reserves using } 2012 \text { prices } \\
\text { (max oil price:gas price, } 1000 \text { s of } \$ 2012 \text { ) }\end{array}$ & $\begin{array}{l}-1.05 \\
(0.49)\end{array}$ & $\begin{array}{c}0.38 \\
(0.63)\end{array}$ & $\begin{array}{c}0.86 \\
(0.28)\end{array}$ & $\begin{array}{c}0.27 \\
(0.22)\end{array}$ & $\begin{array}{c}0.080 \\
(0.026)\end{array}$ & $\begin{array}{c}0.021 \\
(0.010)\end{array}$ \\
\hline$p:=$ coefs. $($ across sex, $2011-15)$ & \multicolumn{2}{|c|}{0.09} & \multicolumn{2}{|c|}{0.06} & \multicolumn{2}{|c|}{0.001} \\
\hline $\begin{array}{l}\text { Simulated reserves in } 2008 \\
\text { (1000s of MMBTUs) }\end{array}$ & $\begin{array}{l}-0.66 \\
(0.59)\end{array}$ & $\begin{array}{c}0.44 \\
(0.62)\end{array}$ & $\begin{array}{c}0.58 \\
(0.27)\end{array}$ & $\begin{array}{c}0.17 \\
(0.22)\end{array}$ & $\begin{array}{c}0.070 \\
(0.022)\end{array}$ & $\begin{array}{c}0.019 \\
(0.009)\end{array}$ \\
\hline$p:=$ coefs. $($ across sex, $2011-15)$ & \multicolumn{2}{|c|}{0.25} & \multicolumn{2}{|c|}{0.26} & \multicolumn{2}{|c|}{0.001} \\
\hline
\end{tabular}

Notes: Underlying sample consists of the $202 \mathrm{CZs}$ in the 14 of the lower 48 states with any major shale gas or oil play (17 states), with available data from the QWI for 2000-2015, and between the 5th and 90th percentile of size (based on average population of 17-18-year-olds over 2000-2005) for their state (202 of 259 CZs for each outcome except the enrollment-to-population ratio, where there are $200 \mathrm{CZs}$ ). The unit of observation is CZ-year-sex. Unless otherwise noted (Panel B), all regressions include state-by-year and CZ fixed effects, as well as time-varying effectsd of each of the 2000 Census CZ characteristics listed in Table 1 Panel D. Cell entries give estimated effects on outcomes as of 201 1-15 for the average CZ in the estimation sample with any shale reserves, calculated from model 2 as described in the text. Regressions for dropout rates (columns 3 and 4) are weighted by the number of Census or ACS respondents used to generate the CZ-year-sex mean dropout rates. Standard errors (in parentheses) are clustered on CZ. 
Table 6 -

Education, Location, or Demographics?

\begin{tabular}{|c|c|c|c|}
\hline & \multicolumn{2}{|c|}{$\begin{array}{c}\text { Effect in 2011-15 in average } \\
\mathrm{CZ} \text { with reserves }>0\end{array}$} & \multirow{2}{*}{$\begin{array}{c}p:=\text { coefs } \\
\text { across } \\
\text { sex, 2011-15 } \\
(3) \\
\end{array}$} \\
\hline & $\frac{\text { Male }}{(1)}$ & $\frac{\text { Female }}{(2)}$ & \\
\hline Preferred specification (dropout) & $\begin{array}{l}1.12 \\
(0.36)\end{array}$ & 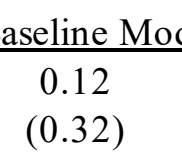 & 0.03 \\
\hline & \multicolumn{3}{|c|}{ B. Effects of Migration } \\
\hline $\begin{array}{l}\text { Outcome is dropout (ages 17-18) } \\
\text { and recent migrant }\end{array}$ & $\begin{array}{l}0.35 \\
(0.24)\end{array}$ & $\begin{array}{c}0.04 \\
(0.21)\end{array}$ & 0.34 \\
\hline $\begin{array}{l}\text { Outcome is dropout (ages 17-18) } \\
\text { and not recent migrant }\end{array}$ & $\begin{array}{c}0.77 \\
(0.25)\end{array}$ & $\begin{array}{c}0.08 \\
(0.25)\end{array}$ & 0.04 \\
\hline $\begin{array}{l}\text { Dropout: Control for shares black, Hispanic, } \\
\text { and recent migrant in } \mathrm{CZ} \text { population }\end{array}$ & $\begin{array}{l}1.13 \\
(0.36)\end{array}$ & $\begin{array}{l}\text { litional Con } \\
0.14 \\
(0.32)\end{array}$ & 0.03 \\
\hline $\begin{array}{l}\text { Dropout: Control for state CSL of } 17 \text { or } 18 \\
\text { (time-varying) } \mathrm{x} \text { reserves }\end{array}$ & $\begin{array}{l}1.20 \\
(0.38)\end{array}$ & $\begin{array}{c}0.07 \\
(0.33)\end{array}$ & 0.02 \\
\hline $\begin{array}{l}\text { Enrollment ratio: Control for state CSL of } 17 \text { or } 18 \\
\text { (time-varying) x reserves }\end{array}$ & $\begin{array}{l}-1.68 \\
(0.83)\end{array}$ & $\begin{array}{l}-0.39 \\
(0.64)\end{array}$ & 0.29 \\
\hline
\end{tabular}

Notes: Underlying sample consists of the $202 \mathrm{CZs}$ in the 14 of the lower 48 states with any major shale gas or oil play (17 states), with available data from the QWI for 2000-2015, and between the 5th and 90th percentile of size (based on average population of 17-18-year-olds over 2000-2005) for their state (202 out of $259 \mathrm{CZs}$ for the dropout rate and $200 \mathrm{of} 259 \mathrm{CZs}$ for the enrollment-to-population ratio). The unit of observation is CZ-year-sex. All regressions include state-by-year and CZ fixed effects, as well as time-varying effects of each of the 2000 Census CZ characteristics listed in Table 1 Panel D. Cell entries give estimated effects on outcomes as of 2011-15 for the average CZ in the estimation sample with any shale reserves, calculated from model 2 as described in the text. Regressions where dropout rates are the dependent variable are weighted by the number of Census or ACS respondents used to generate the CZ-year-sex means. Standard errors (in parentheses) are clustered on $\mathrm{CZ}$. 
Table 7 -

Alternative Mechanisms: Job Opportunities for Teenagers?

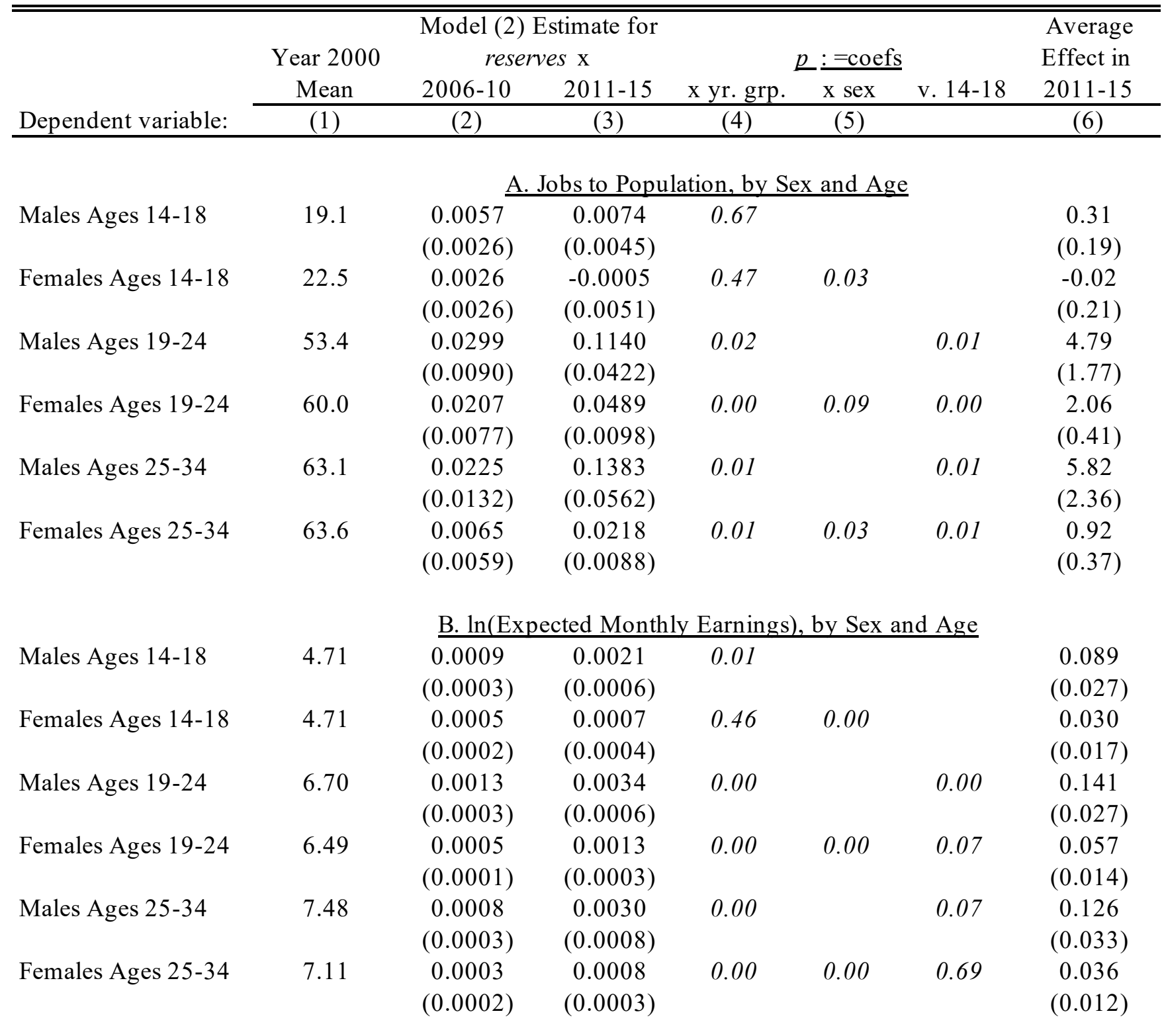

Notes: Underlying sample consists of the $202 \mathrm{CZs}$ in the 14 of the lower 48 states with any major shale gas or oil play (17 states), with available data from the QWI for 2000-2015, and between the 5th and 90th percentile of size (based on average population of 17-18-yearolds over 2000-2005) for their state (202 of 259 CZs). The unit of observation is CZ-year-sex. Data are from the 2000-2015 QWI and SEER. All regressions include state-by-year and CZ fixed effects, as well as time-varying effects of each of the $2000 \mathrm{Census} \mathrm{CZ}$ characteristics listed in Table 1 Panel D. Each CZ is given equal weight. Standard errors (in parentheses) are clustered on CZ. 
Table 8 -

Alternative Mechanisms: Changes in School Resources?

\begin{tabular}{|c|c|c|c|c|c|}
\hline \multirow[b]{4}{*}{ Dependent variable: } & \multicolumn{4}{|c|}{ Model (2) Estimate for } & \multirow{3}{*}{$\begin{array}{l}\text { Average } \\
\text { Effect in } \\
2011-15\end{array}$} \\
\hline & \multirow{2}{*}{$\begin{array}{c}\text { Year } 2000 \\
\text { Mean }\end{array}$} & \multicolumn{2}{|c|}{ reserves $\mathrm{x}$} & \multirow{2}{*}{$\begin{array}{c}p: \\
=\text { coefs }\end{array}$} & \\
\hline & & $2006-10$ & $2011-15$ & & \\
\hline & (1) & $(2)$ & $(3)$ & $(4)$ & $(5)$ \\
\hline Class size & 18.59 & $\begin{array}{c}0.0129 \\
(0.0129)\end{array}$ & $\begin{array}{c}0.0002 \\
(0.0105)\end{array}$ & 0.32 & $\begin{array}{c}0.01 \\
(0.44)\end{array}$ \\
\hline $\ln$ (Total spending per pupil) & 8.95 & $\begin{array}{c}0.0001 \\
(0.0001)\end{array}$ & $\begin{array}{c}0.0001 \\
(0.0002)\end{array}$ & 0.75 & $\begin{array}{c}0.006 \\
(0.009)\end{array}$ \\
\hline $\ln ($ Total revenue per pupil) & 8.95 & $\begin{array}{c}0.0001 \\
(0.0002)\end{array}$ & $\begin{array}{c}0.0003 \\
(0.0002)\end{array}$ & 0.46 & $\begin{array}{c}0.013 \\
(0.008)\end{array}$ \\
\hline $\ln ($ Federal revenue per pupil) & 6.44 & $\begin{array}{l}-0.0000 \\
(0.0001)\end{array}$ & $\begin{array}{l}-0.0004 \\
(0.0002)\end{array}$ & 0.05 & $\begin{array}{l}-0.018 \\
(0.010)\end{array}$ \\
\hline $\ln ($ State revenue per pupil) & 8.21 & $\begin{array}{c}0.0001 \\
(0.0003)\end{array}$ & $\begin{array}{l}-0.0006 \\
(0.0003)\end{array}$ & 0.01 & $\begin{array}{l}-0.023 \\
(0.014)\end{array}$ \\
\hline $\ln$ (Local revenue per pupil) & 7.97 & $\begin{array}{c}0.0001 \\
(0.0002)\end{array}$ & $\begin{array}{c}0.0015 \\
(0.0007)\end{array}$ & 0.02 & $\begin{array}{c}0.063 \\
(0.028)\end{array}$ \\
\hline
\end{tabular}

Notes: Underlying sample consists of the $202 \mathrm{CZs}$ in the 14 of the lower 48 states with any maj or shale gas or oil play (17 states), with available data from the QWI for 2000-2015, and between the 5th and 90th percentile of size (based on average population of 17-18-year-olds over 2000-2005) for their state (202 of $259 \mathrm{CZs}$ ). The unit of observation is CZ-year-sex. Data were drawn from the Common Core of Data for the academic years 1999-2000 to 2014-2015. All regressions include state-byyear and CZ fixed effects, as well as time-varying effects of each of the 2000 Census CZ characteristics listed in Table 1 Panel D. Each $\mathrm{CZ}$ is given equal weight. Standard errors (in parentheses) are clustered on CZ. 


\section{Data Appendix}

\section{A. $\quad$ Estimating Shale Gas and Oil Reserves}

Our preferred approach to predicting CZ reserves relies on the maximum ever (across 2008 to 2015 for gas and 2011 to 2015 for oil) reported reserves for each major shale play, published by the Energy Information Administration (EIA), and the 2011 EIA maps of shale plays. ${ }^{1} \mathrm{We}$ overlay these maps to counties, separately for oil and gas, and allocate maximum reserves to counties based on the fraction of each play that they contain, following a process similar to that of Maniloff and Mastromonaco (2017), who study the local economic impacts of fracking. ${ }^{2}$ A given CZ's oil (gas) reserves are then the sum of these prorated oil (gas) reserves across all counties the $\mathrm{CZ}$ contains. ${ }^{3}$ To combine oil and gas reserves, we convert these predicted reserves into millions of British Thermal Units (MMBTUs), which capture the amount of heating energy that they contain. ${ }^{4}$ Finally, we normalize each CZ's combined predicted oil and gas reserves by its 2000 population to arrive at predicted shale reserves per capita.

\section{B. Data on Gas and Oil Production}

Figure 2, Figure 3A, and Appendix Table A1 were estimated using CZ-by-year aggregates of monthly well-level production data licensed to us under a special agreement with DrillingInfo. The aggregate data give production (thousands of cubic feet of natural gas or barrels of oil) by well type (horizontal or directional versus vertical or unknown).

Following prior research (Feyrer, Mansur, and Sacerdote, 2017), we classify production from horizontal and directional (unconventional) wells as fracking, or as coming from shale. As with our reserve measure, we combine oil and gas production using the conversion to MMBTUs. In Appendix Table A1, however, we also consider the value of production (converted to real 2012 dollars using the energy CPI) as an outcome. To reduce imprecision in the estimates arising from some extreme outliers in these data, we follow Maniloff and Mastromonaco (2017) in also taking the inverse hyperbolic sine (IHS) of these measures. The IHS effectively allows us to take the natural logarithm of production - and coefficients can be interpreted much as they would be in a log-linear model as production levels grow - but retain observations with zero production in the estimation sample.

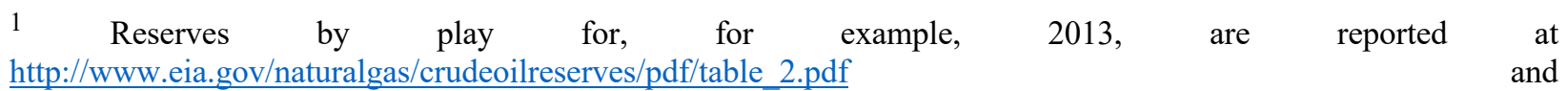
http:/www.eia.gov/naturalgas/crudeoilreserves/pdf/table 4.pdf. The shapefiles for play boundaries can be found at http:/www.eia.gov/pub/oil gas/natural gas/analysis/publications/maps/shalegasplay.zip. We test the robustness of our results to changing various aspects of the prediction in Table 5.

2 Thus, we assign a county $x \%$ of a shale play's estimated reserves if it accounts for $x \%$ of its land area. Unlike Maniloff and Mastromonaco (2017), we use more frequent data and CZs rather counties. We also use the estimated reserves rather than the fraction of each $\mathrm{CZ}$ with reserves to better capture fracking potential. For example, two $\mathrm{CZs}$ with very different reserves would look identical under the latter measure. The latter measure also cannot easily accommodate the fact that some labor markets lie atop multiple shale plays.

3 We allocate counties to CZs (1990 boundaries) using the crosswalk provided by David Dorn: http://www.ddorn.net/data/cw_cty_czone.zip.

4 We use the production conversion factors reported for 2012 by the EIA (http://www.eia.gov/forecasts/aeo/pdf/ appg.pdf): 1,022 BTUs per cubic foot of gas and 5.85 MMBTUs per barrel of oil. 


\section{Census and ACS Microdata}

\section{$\underline{\text { Overview and Key Variables }}$}

The 2000 Census and the 2005 through 2015 American Community Survey (ACS) Public Use Microdata Samples (PUMS) (Ruggles et al., 2015) provide individual-level data on gender, age, school enrollment, and educational attainment, and identify local geography down to the Public Use Microdata Area (PUMA) level. PUMAs are not the same as CZs, but can be allocated to CZs based on the division of county population across PUMAs and the mapping between CZs and counties. ${ }^{5}$ Thus, we are able to estimate sex-specific dropout rates of teenagers at the $\mathrm{CZ}$ level for two pre-fracking years (2000 and 2005) and ten consecutive post-fracking years (2006 through 2015). Unfortunately, no information on PUMA is provided in the public-use ACS PUMS for 2001 to $2004 .^{6}$

We define dropouts as those who have not recently been enrolled in school and do not have a high school degree and limit attention to 17- to 18-year-olds in our main analysis. We focus on the population that is of high school age to mitigate bias from selective migration. That is, by including 19-year-olds or older adults, we would be more concerned that what might appear to be an impact of fracking on education decisions is really an impact of fracking on location choices of existing dropouts. We are interested in how fracking has affected the level of dropout in the economy, not how it has affected the geographic distribution of existing dropouts. Fortunately, by using microdata, we are able to explore the influence of migration on our estimates directly, which we do in Table 6.

\section{$\underline{\text { Considerations }}$}

The reporting period for school enrollment is the prior three months in the ACS (which is conducted in all months of the year) and February 1 in the Census (which is conducted on April 1). These differences in generate several challenges in comparing dropout rates of 17- and 18year-olds across the two surveys, since survey month is not publicly reported in the ACS. First, because school years generally last 180 days, starting in September and ending in May, there is some potential that we misclassify ACS respondents interviewed in the late summer as dropouts, since we do not observe the interview date in the public-use data. Because our analysis includes state-by-year fixed effects, it will account for any resulting bias provided that it does not vary within states over time. Second, with a new school year starting in September, a higher share of the 17- and 18-year-olds surveyed in the fall - and therefore a higher share of 17- and 18-yearolds in the ACS - will be of age to be enrolled in 12th grade or beyond. If teens sometimes make dropout decisions based on grade rather than age, and if that tendency happens to be correlated with reserves, our estimates from the Census/ACS analysis could be biased.

\section{Common Core of Data}

\footnotetext{
${ }^{5}$ Crosswalks between 1990 and 2000 PUMAs and CZs (relevant for the 1990 Census, 2000 Census, and the 20052011 ACS) are available on David Dorn's website: http://www.ddorn.net/data/cw puma2000 czone.zip. We create an analogous crosswalk between 2010 PUMAs and CZs (relevant for the 2012-2015 ACS) using data on the division of 2010 county population across 2010 PUMAs from the Missouri Census Data Center (http://mcdc.missouri.edu) and the county-CZ crosswalk (http://www.ddorn.net/data/cw cty czone.zip).

${ }^{6}$ PUMA codes are not reported in the public-use ACS files for these years.
} 
The Common Core of Data (CCD) is the primary federal database on public schools in the United States. We used the Department of Education's "ELSi tableGenerator"7 to gather aggregated annual county-level CCD data on the number of students by grade and gender (for calculation of the enrollment-to-population ratio $)^{8}$ and the total number of students and teachers (for calculation of the student-teacher ratio/class size).

For several states and years, we are missing sex-specific enrollment data. In these cases, we impute missing values. We first attempt to impute with the product of total enrollment and the sex-specific share in the enrolled population (averaged over 2000-2016). However, this only works when total enrollment is reported. For years where total enrollment is not reported, we impute with linearly interpolated values. These imputations affect a small number of observations. ${ }^{9}$ For the purposes of the enrollment-to-population ratio analysis, we also drop two $\mathrm{CZs}$ in Nebraska that are large outliers on this variable.

\section{E. QWI Data Description}

\section{Overview}

The Quarterly Workforce Indicators (QWI) are a set of quarterly labor market indicators made available by the Longitudinal Employer-Household Dynamics (LEHD) at the U.S. Census Bureau. The LEHD covers over 95 percent of U.S. private sector jobs and is compiled from a variety of sources including state Unemployment Insurance (UI) records, the Quarterly Census of Employment and Wages (QCEW), the Census, Social Security Administrative records, and individual tax returns. Linkages across these data sources enable the LEHD to publish QWI data with detailed firm characteristics and worker demographic information for geographies as small as counties. The near-universe and demographic-specific nature of the QWI is particularly useful for our study, which requires data by sex and education level for local labor markets that often have low populations.

The QWI offers advantages over alternative sources of local economic indicators from the ACS and QCEW. The ACS contains rich information on the characteristics of workers, but it is drawn from a one percent sample of the population. Self-reported earnings in low-population areas further disaggregated by educational attainment and sex can therefore be noisy. In addition, the ACS was only consistently administered from 2005 onwards, while the QWI offer data for earlier years, enabling a more robust analysis of labor market outcomes prior to the onset of fracking. The QCEW provides near-universe data spanning the duration of our study, but it does not contain any demographic details that are critical for our study.

\section{Considerations}

\footnotetext{
${ }^{7}$ Go to https://nces.ed.gov/ccd/elsi/tableGenerator.aspx.

8 The age- and sex-specific population estimates come from SEER (Surveillance, Epidemiology, and End Results Program): https://seer.cancer.gov/popdata/download.html.

${ }^{9}$ The first imputation affects approximately $90 \%$ of enrollment in the average Virginia CZ in $2000,90 \%$ of enrollment in the average Pennsylvania CZ over 2000-04, 8.6\% of enrollment in the average New York CZ over 2000-04, and $2.4 \%$ of enrollment in the average Ohio CZ over 2000-04. The second imputation is relevant for less than $0.3 \%$ of enrollment in the average CZ in all years except 2012 (4\%) and 2015 (7\%).
} 
The QWI data do have some limitations which are important to consider in the context of our analysis. First, because much of the data is collected via a unique federal-state data sharing collaboration, the years of data availability differ by state. While 14 states in our study have data available for our entire analysis timeframe (2000-2015), three states (Arkansas, Kentucky, and Wyoming) are missing some years of data, particularly at the beginning of the study window. We exclude these states in our analysis, but estimates that include data from all 17 states where available look similar to those reported in the paper. The table below details the years of data available in the QWI for the 17 states where at least one CZ overlaps with a major shale play.

QWI Data Availability

\begin{tabular}{|c|c|c|c|}
\hline$\underline{\text { State }}$ & $\underline{\text { Start Date }}$ & $\underline{\text { State }}$ & $\underline{\text { Start Date }}$ \\
\hline AR & 2002: Q3 & NY & 2000: Q1 \\
\hline $\mathrm{CO}$ & 1993: Q2 & $\mathrm{OH}$ & 2000: Q1 \\
\hline KY & 2001: Q1 & OK & 2000: Q1 \\
\hline LA & 1995: Q1 & PA & 1997: Q1 \\
\hline MD & 1999: Q1 & $\mathrm{TX}$ & 1995: Q1 \\
\hline MT & 1993: Q1 & VA & 1998: Q3 \\
\hline ND & 1998: Q1 & WV & 1997: Q1 \\
\hline $\mathrm{NE}$ & 1999: Q1 & WY & 2001: Q1 \\
\hline NM & 1995: Q3 & & \\
\hline
\end{tabular}

Imputations in the published QWI data warrant consideration as well, especially for educationspecific data. QWI documentation states that the vast majority of jobs can be matched to personal characteristics for sex and age variables (97 percent) and geographic variables (over 90 percent), so imputations are less of a concern for these variables. On the other hand, education characteristics primarily rely on an imputation model with a statistical match between the Census and LEHD data using a state-specific logit model that contains age categories, earnings categories, and industry dummies for individuals age 14 and older who reported strictly positive wage earnings. Although this method of imputation likely yields estimates that are generally accurate, it may improperly capture dynamic effects specific to the fracking boom. It also adds noise to our education-specific estimates (Table 3 ).

Finally, the format of the publicly available QWI data limits our analysis in a couple minor ways. First, the online extraction tool for the publicly available QWI data allows for only three separate ways to tabulate data: by sex and age, by sex and education, and by race and ethnicity. We are therefore restricted to analyses based on two-way tabulations. Additionally, data suppression prevents us from undertaking any industry-specific analysis.

\section{Variable Definitions}

Note that the QWI is constructed from firm statistics and therefore represents employment and earnings at the job rather than the individual level. This means that individuals who hold multiple jobs will be counted multiple times in the measures described below.

Jobs-to-Population Ratio: To construct the jobs-to-population ratio used in our study, we create a yearly average of the quarterly total employment reported in the QWI and divide that by 
population estimates ${ }^{10}$ corresponding to the sex by age parameters we select in the QWI. The total employment figure used is defined as the count of people employed in a firm at the beginning of the quarter, which is more of a stock measure than the alternative: the count of people employed in a firm any time during the quarter, which is considered more of a flow measure of jobs. Because this measure is not available until the second quarter of a state's reporting, we are able to construct it using only three quarters of data in the first year that data become available for a state (see table). Overall, this choice does not greatly influence our results as the event study figures are similar when using total quarterly jobs to construct our preferred measure.

Earnings: We construct our preferred earnings measure by taking the beginning quarterly payroll metric in the QWI, dividing by beginning payroll employment to obtain an average quarterly earnings measure, and dividing by 3 to translate this measure to a monthly figure. We convert to an annual measure by taking a weighted average across the four quarters, weighting by beginning of quarter employment in a given quarter. Event study estimates do not meaningfully differ when using total payroll earnings versus beginning of quarter earnings. ${ }^{11}$

\section{Data references}

Feyrer, James, Erin T. Mansur, and Bruce Sacerdote. 2017. "Geographic Dispersion of Economic Shocks: Evidence from the Fracking Revolution." American Economic Review 107(4): 13131334.

Maniloff, Peter and Ralph Mastromonaco. 2017. "The Local Economic Impacts of Hydraulic Fracturing and Determinants of Dutch Disease." Resource and Energy Economics 49: 62-85.

Ruggles, Steven, Katie Genadek, Ronald Goeken, Josiah Grover, and Matthew Sobek. Integrated Public Use Microdata Series: Version 6.0 [dataset]. Minneapolis: University of Minnesota, 2015.

\footnotetext{
${ }^{10}$ The SEER population estimates are available at https://seer.cancer.gov/popdata/download.html.

${ }^{11}$ For further explanation of these data, see https://lehd.ces.census.gov/data, https://lehd.ces.census.gov/doc/QWI_101.pdf, https://lehd.ces.census.gov/doc/technical_paper/tp-2006-01.pdf.
} 


\section{Appendix Figure A1 - Table 5 Specification Checks, Enrollment Ratio}
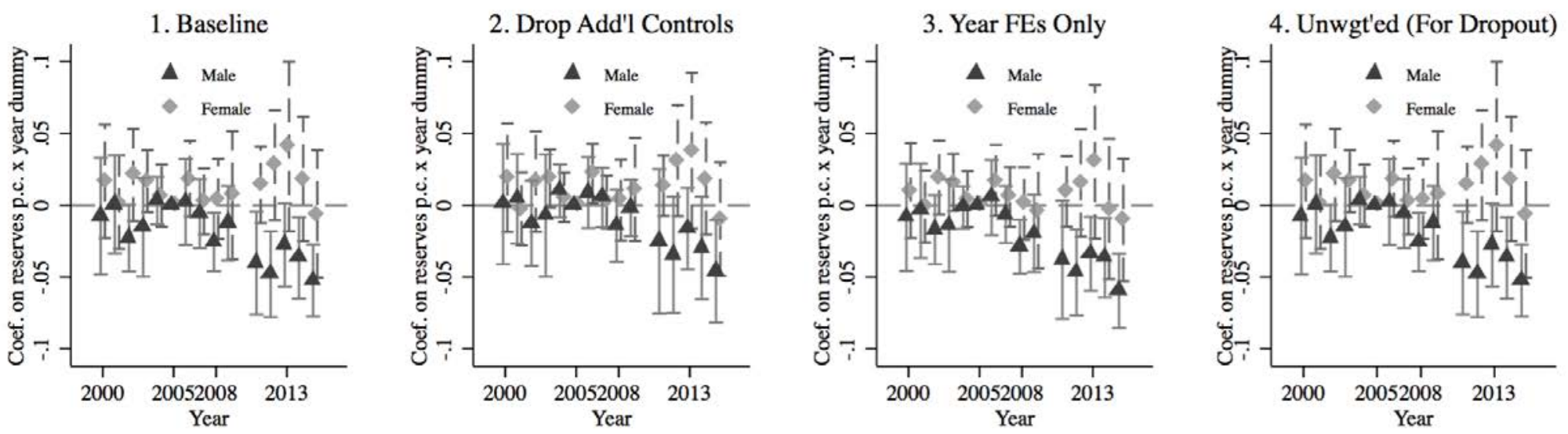

5. Varying 1st Frack Date

6. Value Reserves, 2003

7. Value Reserves, 2012
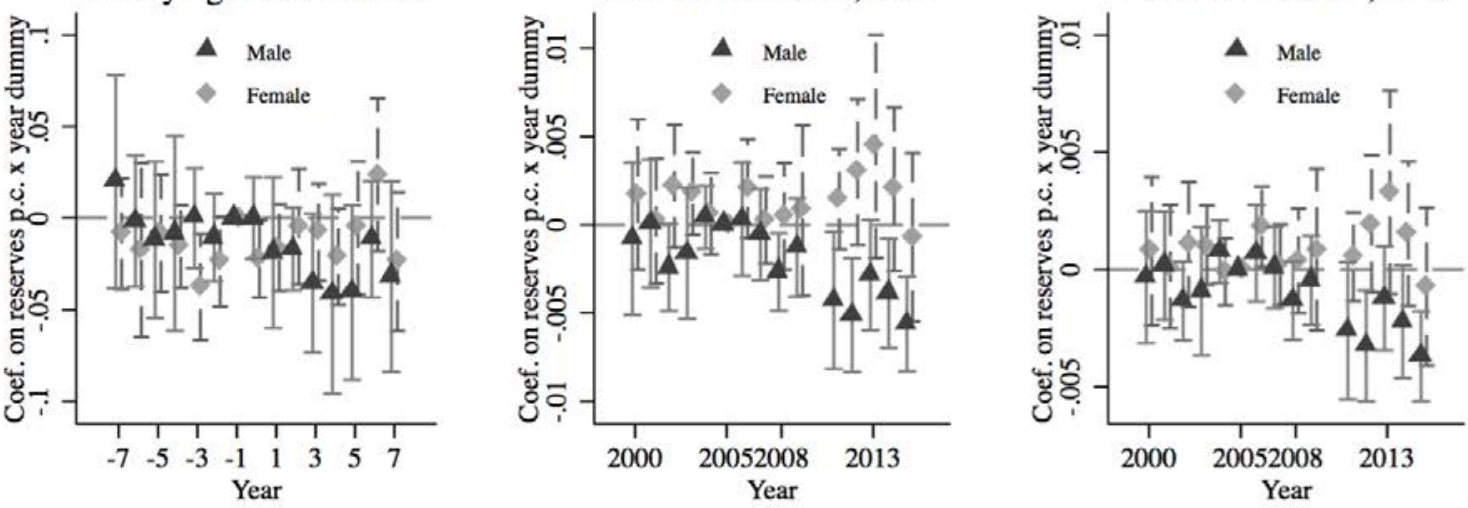

8. 2008 Reserve Est.

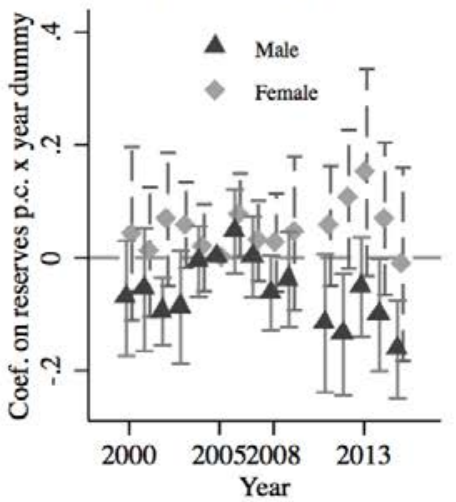

Notes: Graphs plot coefficients on interactions between year dummies and predicted shale oil and gas reserves per capita (measured in 1000s of MMBTUs and normalizing by year $2000 \mathrm{CZ}$ population) (omitting the interaction with the 2005 dummy for identification) from regressions that correspond with each of the specifications presented in Table 5. Inference is robust to heteroskedasticity and error correlation within commuting zones over time. Capped vertical lines represent 90 percent confidence intervals on the coefficient estimates. Data in Panel A are from the Common Core of Data from 1999-00 to 2014-15, and enrollment ratio is defined as the ratio of 11th and 12th grade enrollment to the 17-18-year-old population. Sample is limited to $200 \mathrm{CZs}$ in the 14 analysis states. 


\section{Appendix Figure A2 - \\ Table 5 Specification Checks, Dropout Rate}
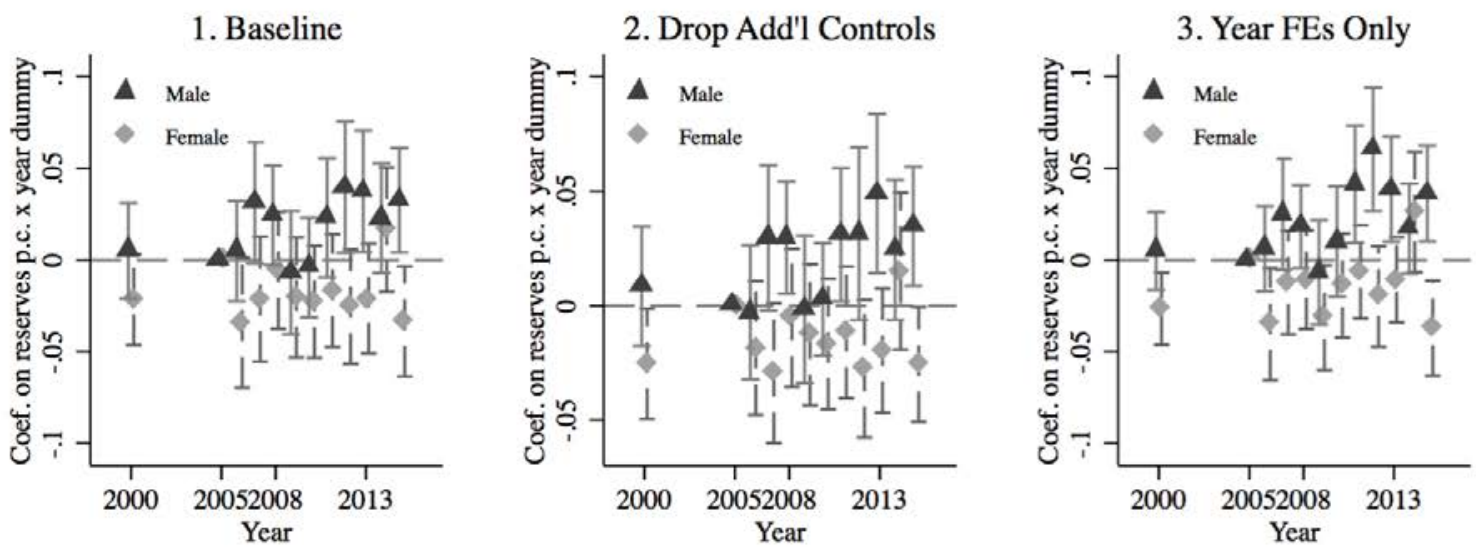

4. Unwgt'ed (For Dropout)

5. Varying 1st Frack Date

6. Value Reserves, 2003

7. Value Reserves, 2012
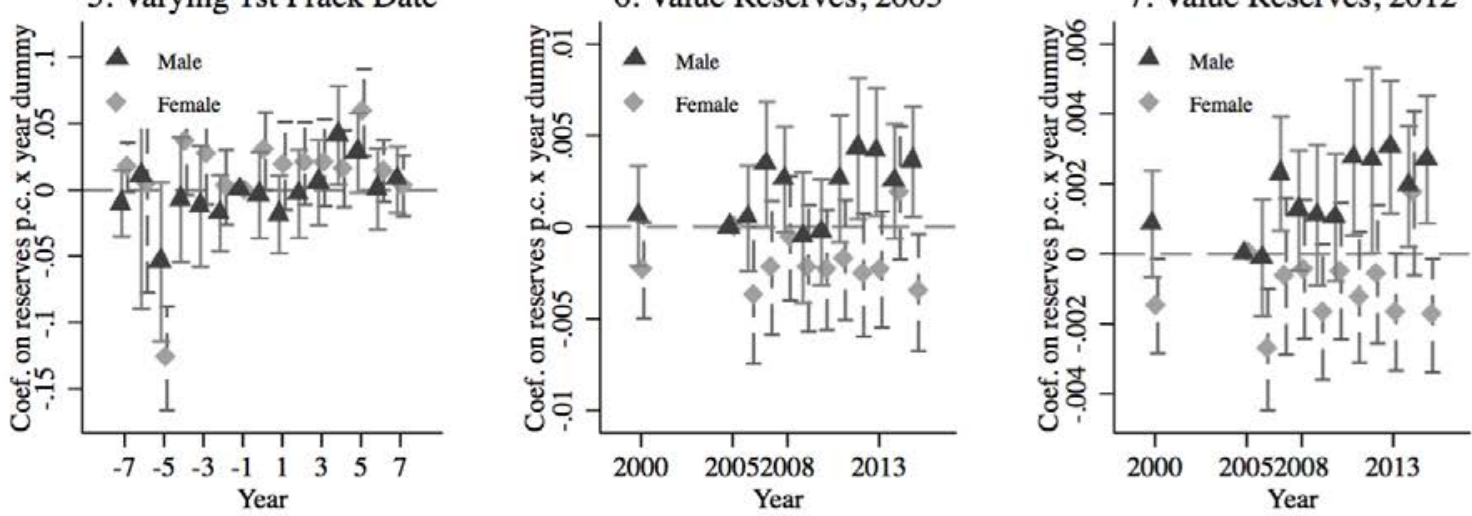

8. 2008 Reserve Est.

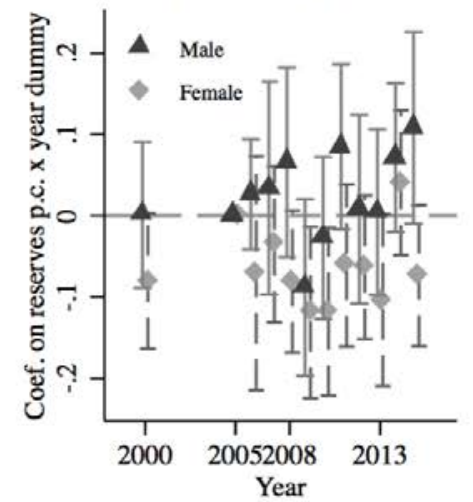

Notes: Graphs plot coefficients on interactions between year dummies and predicted shale oil and gas reserves per capita (measured in 1000s of MMBTUs and normalizing by year $2000 \mathrm{CZ}$ population) (omitting the interaction with the 2005 dummy for identification) from regressions that correspond with each of the specifications presented in Table 5. Inference is robust to heteroskedasticity and error correlation within commuting zones over time. Capped vertical lines represent 90 percent confidence intervals on the coefficient estimates. Data are from the 2000 Census and the 2005-2015 ACS PUMS, and dropout is defined as being not currently enrolled and without a high school degree. Sample is limited to $202 \mathrm{CZs}$ in the 14 analysis states. 


\section{Appendix Figure A3 - Table 5 Specification Checks, $\ln$ (Expected Monthly Earnings)}

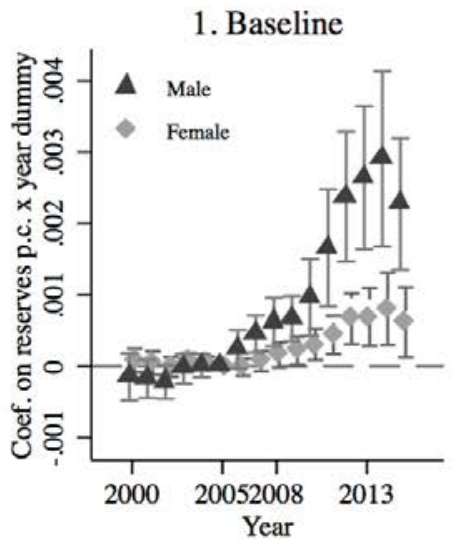

5. Varying 1st Frack Date

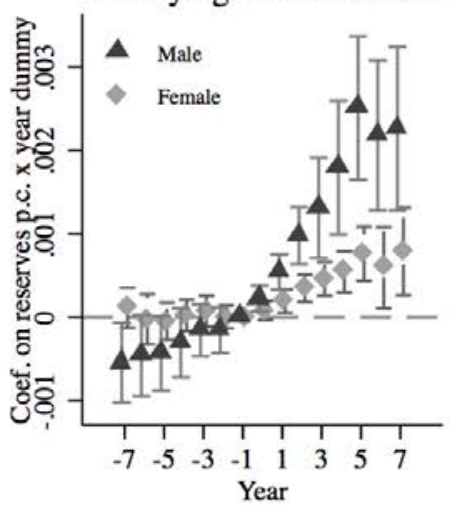

2. Drop Add'l Controls

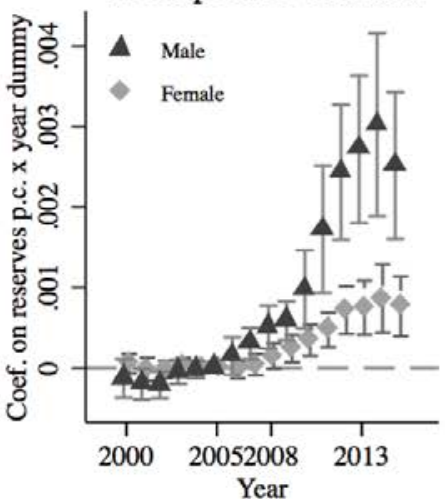

6. Value Reserves, 2003

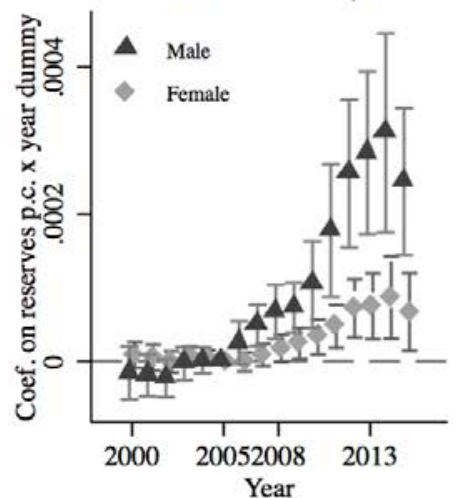

3. Year FEs Only

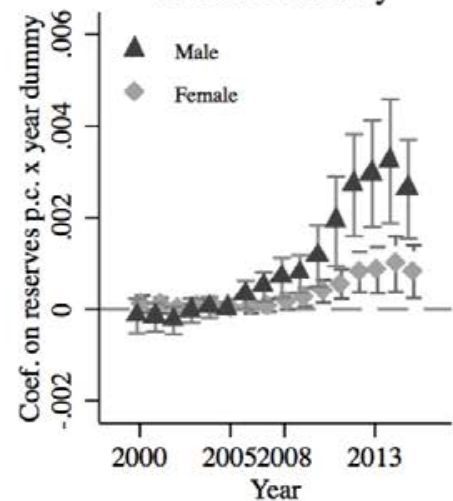

7. Value Reserves, 2012

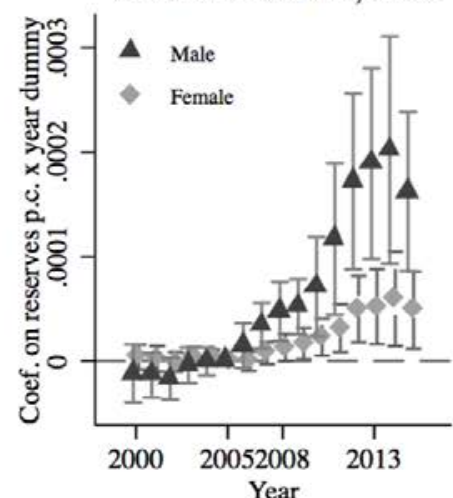

4. Unwgt'ed (For Dropout)

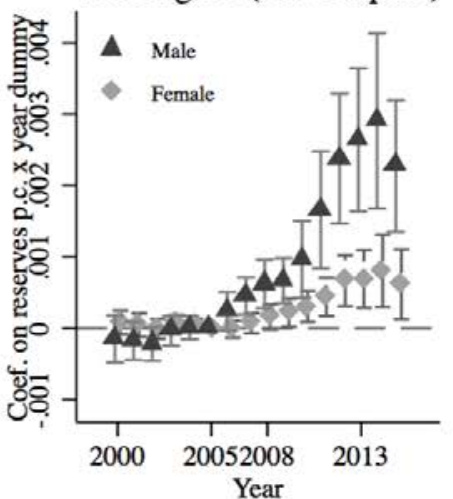

8. 2008 Reserve Est.

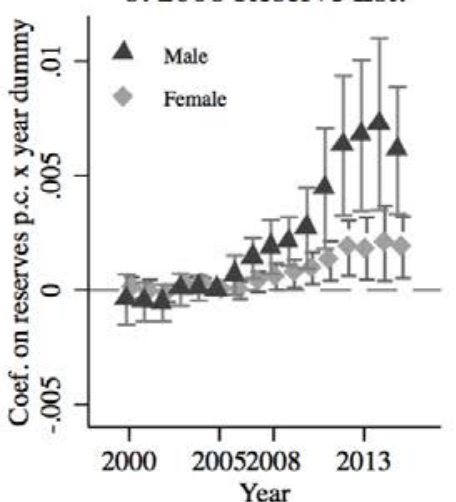

Notes: Graphs plot coefficients on interactions between year dummies and predicted shale oil and gas reserves per capita (measured in 1000s of MMBTUs and normalizing by year $2000 \mathrm{CZ}$ population) (omitting the interaction with the 2005 dummy for identification) from regressions that correspond with each of the specifications presented in Table 5. Inference is robust to heteroskedasticity and error correlation within commuting zones over time. Capped vertical lines represent 90 percent confidence intervals on the coefficient estimates. Data are from the Quarterly Workforce Indicators (Panel B) and span 2000-2015; see Data Appendix. Sample is limited to 202 CZs in the 14 analysis states. 


\section{Appendix Figure A4 - Table 6 Robustness Checks}
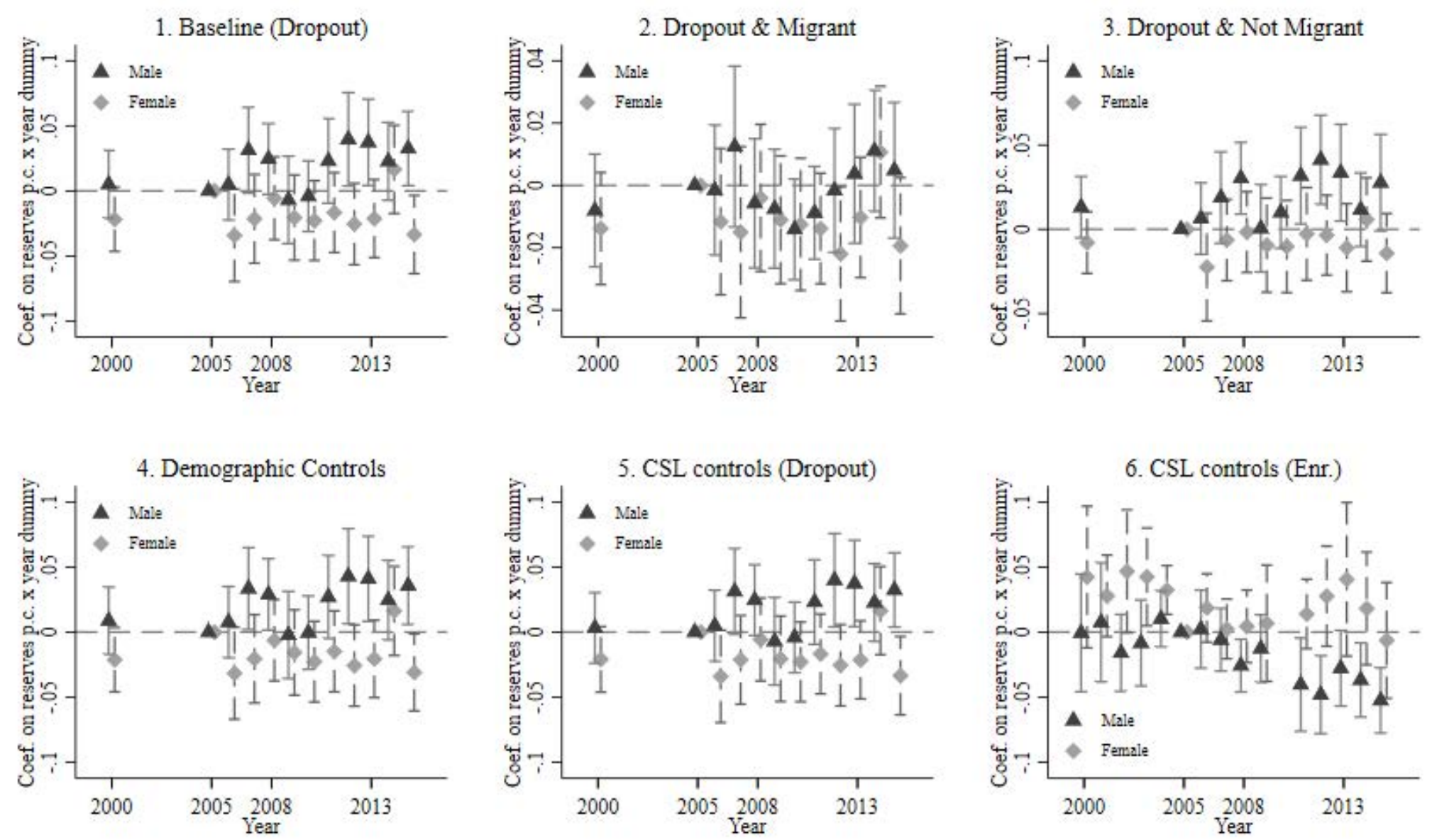

Notes: Graphs plot coefficients on interactions between year dummies and predicted shale oil and gas reserves per capita (measured in 1000s of MMBTUs and normalizing by year $2000 \mathrm{CZ}$ population) (omitting the interaction with the 2005 dummy for identification) from regressions that correspond with each of the specifications presented in Table 6 . Inference is robust to heteroskedasticity and error correlation within commuting zones over time. Capped vertical lines represent 90 percent confidence intervals on the coefficient estimates. Data in Panels 1-5 are from the 2000 Census and the 2005-2015 ACS PUMS, and dropout is defined as being not currently enrolled and without a high school degree. Data in Panel 6 are from the Common Core of Data from 1999-00 to 2014-15, and enrollment ratio is defined as the ratio of 11th and 12th grade enrollment to the 17-18-year-old population. See Data Appendix. Sample is limited to $202 \mathrm{CZs}$ (Panels 1-5) or $200 \mathrm{CZ}$ (Panel 6) in the 14 analysis states. 


\section{Appendix Figure A5 - \\ Table 7 Male Jobs and Expected Earnings by Age}
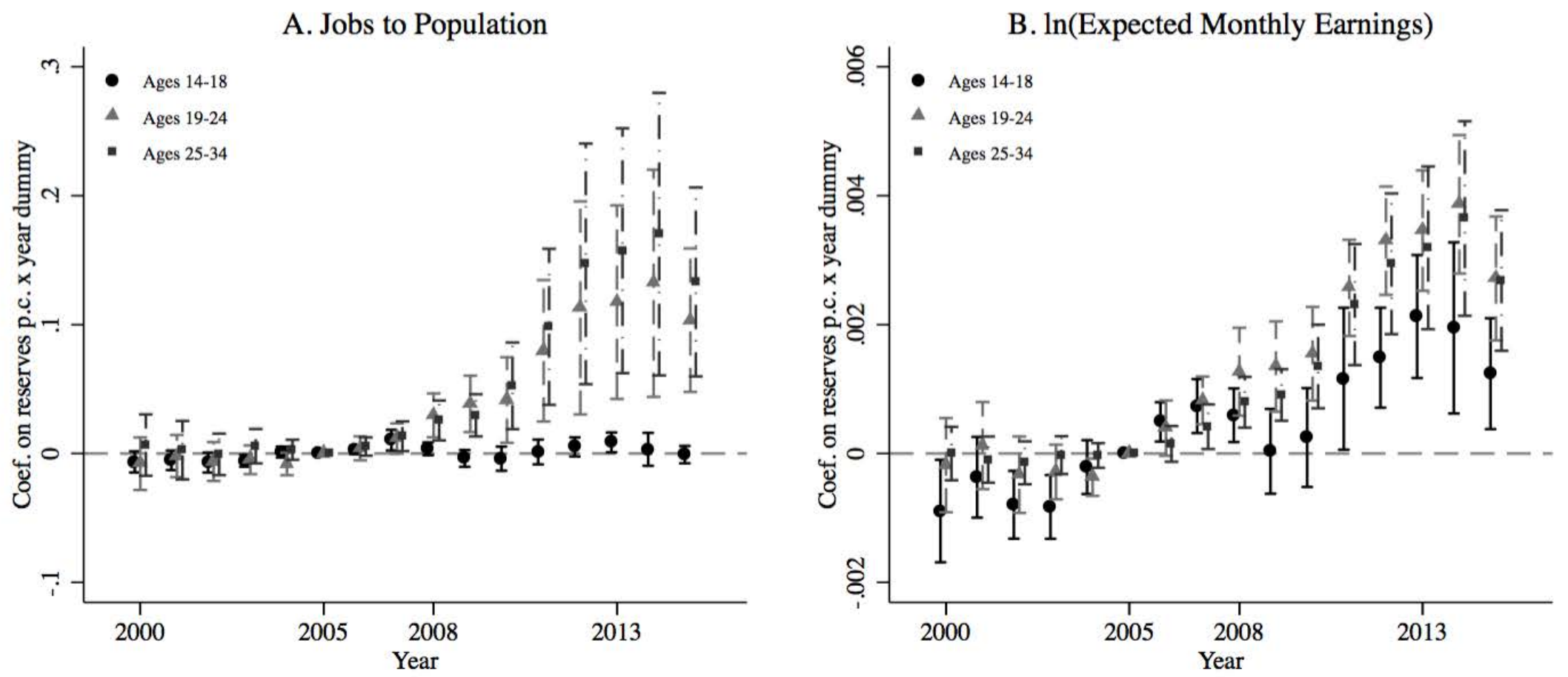

Notes: Graphs plot coefficients on interactions between year dummies and predicted shale oil and gas reserves per capita (measured in 1000s of MMBTUs and normalizing by year $2000 \mathrm{CZ}$ population) (omitting the interaction with the 2005 dummy for identification) from regressions that correspond with each of the specifications presented in Table 7. Inference is robust to heteroskedasticity and error correlation within commuting zones over time. Capped vertical lines represent 90 percent confidence intervals on the coefficient estimates. Data are from the Quarterly Workforce Indicators (Panel B) and span 2000-2015; see Data Appendix. Sample is limited to 202 CZs in the 14 analysis states. 


\section{Appendix Figure A6 - Table 8 School Resources}

A. $\ln$ Total P.P. Resources

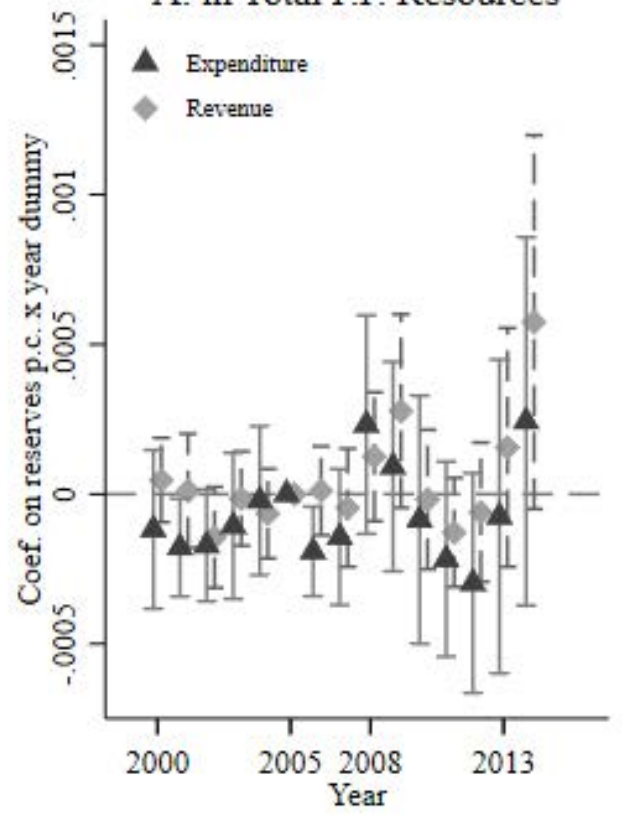

B. In P.P. Rev by Source

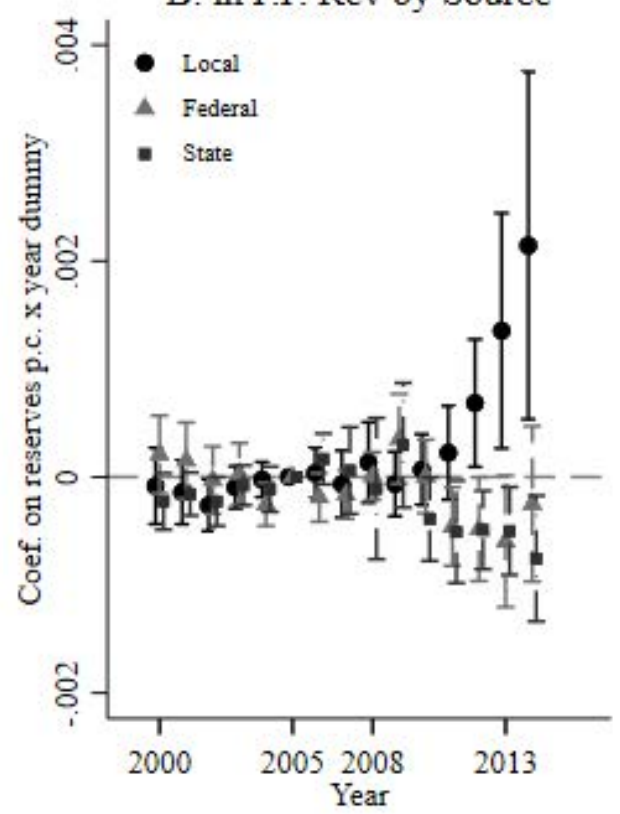

C. Class Size

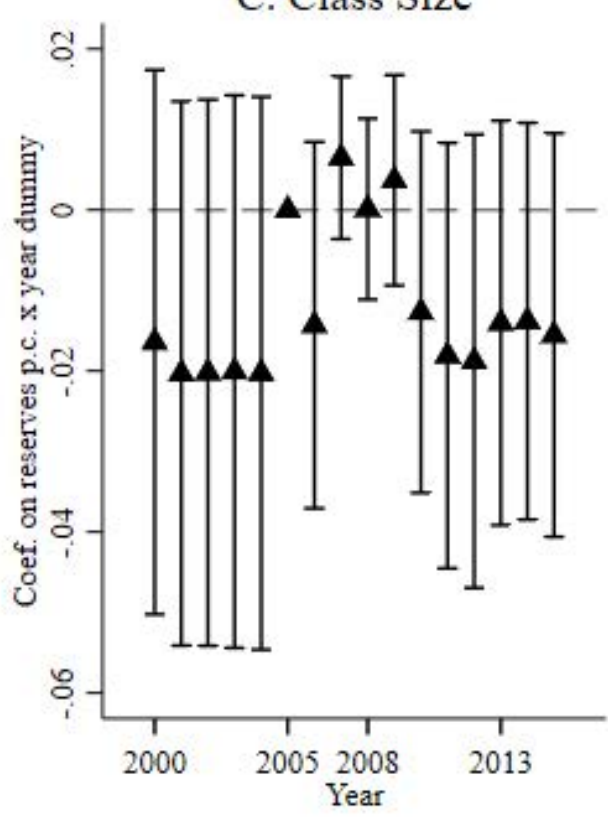

Notes: Graphs plot coefficients on interactions between year dummies and predicted shale oil and gas reserves per capita (measured in 1000s of MMBTUs and normalizing by year $2000 \mathrm{CZ}$ population) (omitting the interaction with the 2005 dummy for identification) from regressions that correspond with each of the specifications presented in Table 8. Inference is robust to heteroskedasticity and error correlation within commuting zones over time. Capped vertical lines represent 90 percent confidence intervals on the coefficient estimates. Data are from the Census of Governments and Annual Surveys of State and Local Government Finances (Panels A and B) and the Common Core of Data (Panel C) and span 2000-2015. Sample is limited to 202 CZs in the 14 analysis states. 
Appendix Table A1 -

The Effect of Shale Oil and Gas Reserves and the Introduction of Fracking on

Oil and Gas Production

\begin{tabular}{|c|c|c|c|c|c|c|}
\hline \multirow{3}{*}{ Dependent Variable: } & \multicolumn{4}{|c|}{$\begin{array}{l}\text { Per-capita Shale Oil } \\
\text { and Gas Production }\end{array}$} & \multicolumn{2}{|c|}{$\begin{array}{c}\text { Per-capita Conventional Oi } \\
\text { and Gas Production }\end{array}$} \\
\hline & $\begin{array}{l}\text { in 1000s of } \\
\text { MMBTUs }\end{array}$ & $\begin{array}{c}\text { Inverse Hyperbolic Sine } \\
\text { of MMBTUs }\end{array}$ & $\begin{array}{l}\text { in } 1000 \text { s of } \\
\text { real } \$ 2012\end{array}$ & $\begin{array}{l}\text { Inverse Hyperbolic Sine } \\
\text { of value }\end{array}$ & $\begin{array}{l}\text { in } 1000 \text { s of } \\
\text { real } \$ 2012\end{array}$ & $\begin{array}{l}\text { in 1000s of } \\
\text { MMBTUs }\end{array}$ \\
\hline & $(1)$ & $(2)$ & $(3)$ & $(4)$ & $(5)$ & $(6)$ \\
\hline Average effect $2011-15$, reserves $>0$ & $\begin{array}{c}1.58 \\
(0.80)\end{array}$ & $\begin{array}{c}0.26 \\
(0.09)\end{array}$ & $\begin{array}{l}18.10 \\
(9.76)\end{array}$ & $\begin{array}{c}0.41 \\
(0.12)\end{array}$ & $\begin{array}{c}0.01 \\
(0.08)\end{array}$ & $\begin{array}{l}-0.02 \\
(0.53)\end{array}$ \\
\hline \multicolumn{7}{|l|}{ Coefficient on: } \\
\hline $\begin{array}{l}\text { Shale reserves per capita } \\
\qquad \times \text { 2006-10 }\end{array}$ & $\begin{array}{c}0.0060 \\
(0.0045)\end{array}$ & $\begin{array}{c}0.0018 \\
(0.0008)\end{array}$ & $\begin{array}{c}0.0764 \\
(0.0648)\end{array}$ & $\begin{array}{c}0.0037 \\
(0.0011)\end{array}$ & $\begin{array}{l}-0.0002 \\
(0.0010)\end{array}$ & $\begin{array}{c}0.0059 \\
(0.0062)\end{array}$ \\
\hline $\begin{array}{l}\text { Shale reserves per capita } \\
\qquad \text { x 2011-15 }\end{array}$ & $\begin{array}{c}0.0375 \\
(0.0190)\end{array}$ & $\begin{array}{c}0.0062 \\
(0.0021)\end{array}$ & $\begin{array}{c}0.4303 \\
(0.2319)\end{array}$ & $\begin{array}{c}0.0097 \\
(0.0029)\end{array}$ & $\begin{array}{c}0.0002 \\
(0.0020)\end{array}$ & $\begin{array}{c}-0.0004 \\
(0.0125)\end{array}$ \\
\hline$p:=$ coefs. (across yr. groups) & 0.039 & 0.007 & 0.043 & 0.008 & 0.759 & 0.626 \\
\hline Observations & 3,232 & 3,232 & 3,232 & 3,232 & 3,232 & 3,232 \\
\hline R-squared & 0.616 & 0.799 & 0.661 & 0.880 & 0.891 & 0.935 \\
\hline
\end{tabular}

Notes: Underlying sample consists of the $202 \mathrm{CZs}$ in the 14 of the lower 48 states with any major shale gas or oil play ( 17 states), with available data from the QWI for $2000-2015$, and between the 5th and 90th percentile of size (based on average population of 17-18-year-olds over 2000-2005) for their state (202 of 259 CZs). The unit of observation is CZ-year. Data on oil and gas production by well type are from DrillingInfo from 2000-2015 and are converted into 2012 dollars using the energy CPI and MMBtus using 2012 conversion factors reported by EIA. All regressions include state-by-year fixed effects, commuting zone fixed effects, and time-varying effects of each of the 2000 Census commuting zone characteristics listed in Table 1 Panel D. 
Appendix Table A2 -

The Effect of Shale Oil and Gas Reserves and the Introduction of Fracking

on Jobs to Population, by Sex and Educational Attainment:

Coefficients for Table 3

\begin{tabular}{|c|c|c|c|c|}
\hline \multirow{3}{*}{ Dependent variable: } & \multicolumn{4}{|c|}{ Jobs (by Education) to Group Population, Ages 25+ } \\
\hline & $\begin{array}{l}\text { High Sch. } \\
\text { Dropouts }\end{array}$ & $\begin{array}{l}\text { High Sch. } \\
\text { Graduates }\end{array}$ & $\begin{array}{c}\text { College } \\
\text { Attendees }\end{array}$ & $\begin{array}{c}\text { College } \\
\text { Graduates }\end{array}$ \\
\hline & $(1)$ & $(2)$ & $(3)$ & $(4)$ \\
\hline & \multicolumn{4}{|c|}{ A. $\operatorname{Men}(\mathrm{N}=3,232)$} \\
\hline Shale reserves per capita & 0.0162 & 0.0185 & 0.0245 & 0.0067 \\
\hline x 2006-10 & $(0.0098)$ & $(0.0086)$ & $(0.0128)$ & $(0.0029)$ \\
\hline Shale reserves per capita & 0.1666 & 0.1096 & 0.1440 & 0.0385 \\
\hline x 2011-15 & $(0.0697)$ & $(0.0471)$ & $(0.0589)$ & $(0.0160)$ \\
\hline$p:=$ coefs. $($ across yr. groups) & 0.015 & 0.020 & 0.011 & 0.021 \\
\hline \multirow[t]{2}{*}{ R-squared } & 0.902 & 0.864 & 0.893 & 0.964 \\
\hline & \multicolumn{4}{|c|}{ B. Women $(\mathrm{N}=3,232)$} \\
\hline Shale reserves per capita & -0.0042 & 0.0021 & 0.0100 & -0.0014 \\
\hline x 2006-10 & $(0.0099)$ & $(0.0035)$ & $(0.0052)$ & $(0.0027)$ \\
\hline Shale reserves per capita & 0.0146 & 0.0131 & 0.0316 & 0.0036 \\
\hline x 2011-15 & $(0.0177)$ & $(0.0068)$ & $(0.0082)$ & $(0.0042)$ \\
\hline$p:=$ coefs. (across yr. groups) & 0.055 & 0.017 & 0.000 & 0.042 \\
\hline \multirow[t]{2}{*}{ R-squared } & 0.973 & 0.953 & 0.971 & 0.975 \\
\hline & \multicolumn{4}{|c|}{ C. Male-Female Difference $(\mathrm{N}=6,464)$} \\
\hline Shale reserves per capita & 0.0204 & 0.0164 & 0.0145 & 0.0081 \\
\hline x 2006-10 & $(0.0136)$ & $(0.0082)$ & $(0.0114)$ & $(0.0021)$ \\
\hline Shale reserves per capita & 0.1520 & 0.0965 & 0.1123 & 0.0349 \\
\hline x 2011-15 & $(0.0664)$ & $(0.0420)$ & $(0.0533)$ & $(0.0129)$ \\
\hline$p:=$ coefs. (across yr. groups) & 0.019 & 0.022 & 0.024 & 0.028 \\
\hline$p:=$ coefs $($ across sex, $2011-15)$ & 0.023 & 0.023 & 0.036 & 0.008 \\
\hline R-squared & 0.933 & 0.887 & 0.927 & 0.969 \\
\hline
\end{tabular}

Notes: Underlying sample consists of the $202 \mathrm{CZs}$ in the 14 of the lower 48 states with any major shale gas or oil play (17 states), with available data from the QWI for 2000-2015, and between the 5th and 90th percentile of size (based on average population of 17-18-year-olds over 2000-2005) for their state (202 of 259 CZs). The unit of observation is CZ-year-sex. Data on jobs for individuals ages 25 and over are from the 2000-2015 QWI and correspond to unweighted averages of beginning of quarter figures reported throughout the year; data on the population ages 25 and over are from SEER; and estimates of education shares in the population ages 25-64 are from the Census and ACS. Ratios multiply group-specific jobs by group-specific population, estimated as the product of population and the relevant group share in the population. Cell entries give coefficients (standard errors) from model 2 (Panels A and B) or a fully-interacted version of model 2 using pooled data (Panel C). All regressions include state-by-year and $\mathrm{CZ}$ fixed effects and time-varying effects of the CZ observables summarized in Table 1 Panel D. Each CZ is given equal weight in the estimation. Standard errors clustered on CZ are in parentheses. 
Appendix Table A3 -

The Effect of Shale Oil and Gas Reserves and the Introduction of Fracking

on Expected Monthly Earnings, by Sex and Educational Attainment:

Coefficients for Table 3

\begin{tabular}{|c|c|c|c|c|}
\hline \multirow{3}{*}{ Dependent variable: } & \multicolumn{4}{|c|}{$\ln$ (Expected Monthly Earnings) } \\
\hline & $\begin{array}{l}\text { High Sch. } \\
\text { Dropouts }\end{array}$ & $\begin{array}{l}\text { High Sch. } \\
\text { Graduates }\end{array}$ & $\begin{array}{c}\text { College } \\
\text { Attendees }\end{array}$ & $\begin{array}{c}\text { College } \\
\text { Graduates }\end{array}$ \\
\hline & $(1)$ & $(2)$ & $(3)$ & $(4)$ \\
\hline & \multicolumn{4}{|c|}{ A. $\operatorname{Men}(\mathrm{N}=3,232)$} \\
\hline Shale reserves per capita & 0.0009 & 0.0008 & 0.0007 & 0.0004 \\
\hline x 2006-10 & $(0.0003)$ & $(0.0003)$ & $(0.0003)$ & $(0.0002)$ \\
\hline Shale reserves per capita & 0.0030 & 0.0027 & 0.0025 & 0.0016 \\
\hline x 2011-15 & $(0.0008)$ & $(0.0006)$ & $(0.0006)$ & $(0.0006)$ \\
\hline$p:=$ coefs. (across yr. groups) & 0.000 & 0.000 & 0.000 & 0.004 \\
\hline \multirow[t]{2}{*}{ R-squared } & 0.942 & 0.932 & 0.939 & 0.962 \\
\hline & \multicolumn{4}{|c|}{ B. Women $(\mathrm{N}=3,232)$} \\
\hline Shale reserves per capita & 0.0003 & 0.0002 & 0.0002 & -0.0001 \\
\hline x 2006-10 & $(0.0002)$ & $(0.0001)$ & $(0.0001)$ & $(0.0001)$ \\
\hline Shale reserves per capita & 0.0012 & 0.0007 & 0.0007 & 0.0002 \\
\hline x 2011-15 & $(0.0004)$ & $(0.0003)$ & $(0.0002)$ & $(0.0002)$ \\
\hline$p:=$ coefs. (across yr. groups) & 0.001 & 0.004 & 0.000 & 0.026 \\
\hline \multirow[t]{2}{*}{ R-squared } & 0.971 & 0.942 & 0.954 & 0.968 \\
\hline & \multicolumn{4}{|c|}{ C. Male-Female Difference $(\mathrm{N}=6,464)$} \\
\hline Shale reserves per capita & 0.0006 & 0.0006 & 0.0005 & 0.0005 \\
\hline x 2006-10 & $(0.0002)$ & $(0.0002)$ & $(0.0002)$ & $(0.0001)$ \\
\hline Shale reserves per capita & 0.0018 & 0.0020 & 0.0018 & 0.0014 \\
\hline x 2011-15 & $(0.0006)$ & $(0.0004)$ & $(0.0004)$ & $(0.0004)$ \\
\hline$p:=$ coefs. $($ across yr. groups) & 0.008 & 0.000 & 0.000 & 0.004 \\
\hline$p:=$ coefs. $($ across sex, $2011-15)$ & 0.002 & 0.000 & 0.000 & 0.001 \\
\hline R-squared & 0.973 & 0.964 & 0.955 & 0.970 \\
\hline
\end{tabular}

Notes: Underlying sample consists of the $202 \mathrm{CZs}$ in the 14 of the lower 48 states with any major shale gas or oil play (17 states), with available data from the QWI for 2000-2015, and between the 5th and 95th percentile of size (based on 2000 population) for their state $(202$ of $259 \mathrm{CZs})$. The unit of observation is CZ-year-sex. Data on monthly earnings for individuals ages 25 and over are from the 2000-2015 QWI and correspond to unweighted averages of beginning of quarter figures reported throughout the year. Expected monthly earnings multiply reported monthly earnings by the group-specific jobs-to-population ratio. Cell entries give coefficients (standard errors) from model 2 (Panels A and B) or a fully-interacted version of model 2 using pooled data (Panel C). All regressions include state-by-year and $\mathrm{CZ}$ fixed effects and time-varying effects of the $\mathrm{CZ}$ observables summarized in Table 1 Panel D. Each CZ is given equal weight in the estimation. Standard errors clustered on CZ are in parentheses. 
Appendix Table A4 -

Sensitivity of the Estimates for Dropout, Enrollment, and Earnings to Choice of Specification Coefficients for Table 5, Panel B

\begin{tabular}{|c|c|c|c|c|c|c|}
\hline \multirow[t]{3}{*}{ Dependent variable: } & \multicolumn{2}{|c|}{$\begin{array}{c}\text { Enrollment ratio, } \\
\text { Gr 11-12: Ages 17-18 }\end{array}$} & \multicolumn{2}{|c|}{ Dropout, Ages 17-18 } & \multicolumn{2}{|c|}{$\begin{array}{c}\ln (\text { Expected Earnings }) \\
\text { Ages } 25+\end{array}$} \\
\hline & Male & Female & Male & Female & Male & Female \\
\hline & $(1)$ & $(2)$ & $(3)$ & $(4)$ & $(5)$ & $(6)$ \\
\hline & \multicolumn{6}{|c|}{ No time-varying effects of CZ observables } \\
\hline Shale reserves per capita & 0.0002 & 0.0002 & 0.0040 & 0.0053 & 0.0006 & 0.0001 \\
\hline x 2006-10 & $(0.0136)$ & $(0.0123)$ & $(0.0087)$ & $(0.0079)$ & $(0.0002)$ & $(0.0001)$ \\
\hline Shale reserves per capita & -0.0297 & 0.0088 & 0.0269 & 0.0083 & 0.0026 & 0.0007 \\
\hline x 2011-15 & $(0.0150)$ & $(0.0148)$ & $(0.0103)$ & $(0.0087)$ & $(0.0006)$ & $(0.0002)$ \\
\hline$p:=$ coefs (across yr. groups) & 0.129 & 0.449 & 0.003 & 0.678 & 0.000 & 0.000 \\
\hline \multirow[t]{2}{*}{ R-squared } & 0.746 & 0.759 & 0.496 & 0.450 & 0.932 & 0.949 \\
\hline & \multicolumn{6}{|c|}{ Year fixed effects } \\
\hline Shale reserves per capita & -0.0049 & -0.0031 & 0.0063 & 0.0020 & 0.0008 & 0.0001 \\
\hline x 2006-10 & $(0.0149)$ & $(0.0135)$ & $(0.0074)$ & $(0.0073)$ & $(0.0003)$ & $(0.0001)$ \\
\hline Shale reserves per capita & -0.0355 & 0.0003 & 0.0349 & 0.0135 & 0.0028 & 0.0008 \\
\hline x 2011-15 & $(0.0146)$ & $(0.0189)$ & $(0.0096)$ & $(0.0076)$ & $(0.0007)$ & $(0.0003)$ \\
\hline$p:=$ coefs (across yr. groups) & 0.094 & 0.779 & 0.000 & 0.106 & 0.000 & 0.004 \\
\hline \multirow[t]{2}{*}{ R-squared } & 0.715 & 0.732 & 0.478 & 0.419 & 0.927 & 0.941 \\
\hline & \multicolumn{6}{|c|}{ Unweighted Estimates (Changes Dropout Only Relative to Baseline) } \\
\hline Shale reserves per capita & -0.0035 & -0.0024 & 0.0107 & -0.0105 & 0.0007 & 0.0001 \\
\hline x 2006-10 & $(0.0163)$ & $(0.0166)$ & $(0.0038)$ & $(0.0060)$ & $(0.0002)$ & $(0.0001)$ \\
\hline Shale reserves per capita & -0.0340 & 0.0085 & 0.0244 & -0.0013 & 0.0025 & 0.0006 \\
\hline x 2011-15 & $(0.0151)$ & $(0.0192)$ & $(0.0055)$ & $(0.0053)$ & $(0.0006)$ & $(0.0002)$ \\
\hline$p:=$ coefs (across yr. groups) & 0.065 & 0.385 & 0.00 & 0.07 & 0.00 & 0.00 \\
\hline R-squared & 0.764 & 0.777 & 0.360 & 0.373 & 0.936 & 0.954 \\
\hline \multicolumn{7}{|c|}{$\begin{array}{l}\text { Notes: Underlying sample consists of the } 202 \mathrm{CZs} \text { in the } 14 \text { of the lower } 48 \text { states with any major shale gas or oil play ( } 17 \text { states), with available data from the } \\
\text { QWI for } 2000-2015 \text {, and between the } 5 \text { th and } 90 \text { th percentile of size (based on average population of } 17-18 \text {-year-olds over } 2000-2005) \text { for their state (202 of } 259 \\
\text { CZs for each outcome except the enrollment-to-population ratio, where there are } 200 \mathrm{CZs).} \mathrm{The} \mathrm{unit} \mathrm{of} \mathrm{observation} \mathrm{is} \mathrm{CZ-year-sex.} \mathrm{Unless} \mathrm{otherwise} \mathrm{noted} \\
\text { (Panel B), all regressions include state-by-year and CZ fixed effects, as well as time-varying effectsd of each of the } 2000 \text { Census CZ characteristics listed in } \\
\text { Table } 1 \text { Panel D. Cell entries give estimated effects on outcomes as of } 2011-15 \text { for the average CZ in the estimation sample with any shale reserves, calculated } \\
\text { from model } 2 \text { as described in the text. Regressions for dropout rates (columns } 3 \text { and 4) are weighted by the number of Census or ACS respondents used to } \\
\text { generate the CZ-year-sex mean dropout rates. Standard errors (in parentheses) are clustered on CZ. }\end{array}$} \\
\hline
\end{tabular}


Appendix Table A5 -

Sensitivity of the Estimates for Dropout, Enrollment, and Earnings to Choice of Specification

Coefficients for Table 5, Panel C

\begin{tabular}{|c|c|c|c|}
\hline Dependent variable: & $\begin{array}{c}\text { Enrollment ratio, } \\
\text { Gr 11-12: Ages 17-18 }\end{array}$ & Dropout, Ages 17-18 & $\begin{array}{c}\ln (\text { Expected Earnings }) \\
\text { Ages } 25+\end{array}$ \\
\hline & Male Female & Male Female & Male Female \\
\hline & $(2)$ & $(4)$ & $(6)$ \\
\hline
\end{tabular}

Shale reserves per capita

$\begin{array}{cccccc}-0.0239 & 0.0053 & 0.0162 & 0.0105 & 0.0018 & 0.0005 \\ (0.0108) & (0.0162) & (0.0072) & (0.0068) & (0.0005) & (0.0002) \\ 0.763 & 0.776 & 0.538 & 0.494 & 0.934 & 0.954\end{array}$

R-squared

x post-fracking

0.763

0.776

0.538

0.494

0.934

0.954

Shale reserves per capita

$-0.0334$

Long difference: 2000 versus 2011-15

x 2011-15

$(0.0265)$

0.0024

0.0248

0.0057

0.0025

0.0006

R-squared

0.795

0.808

$(0.0097)$

$(0.0083)$

$(0.0007)$

$(0.0003)$

Notes: Underlying sample consists of the $202 \mathrm{CZs}$ in the 14 of the lower 48 states with any major shale gas or oil play ( 17 states), with available data from the QWI for 2000-2015, and between the 5th and 90th percentile of size (based on average population of 17-18-year-olds over 2000-2005) for their state (202 of 259 $\mathrm{CZs}$ for each outcome except the enrollment-to-population ratio, where there are $200 \mathrm{CZs}$ ). The unit of observation is CZ-year-sex. Unless otherwise noted (Panel B), all regressions include state-by-year and CZ fixed effects, as well as time-varying effectsd of each of the 2000 Census CZ characteristics listed in Table 1 Panel D. Cell entries give estimated effects on outcomes as of 2011-15 for the average CZ in the estimation sample with any shale reserves, calculated from model 2 as described in the text. Regressions for dropout rates (columns 3 and 4) are weighted by the number of Census or ACS respondents used to generate the CZ-year-sex mean dropout rates. Standard errors (in parentheses) are clustered on CZ. 
Appendix Table A6 -

Sensitivity of the Estimates for Dropout, Enrollment, and Earnings to Choice of Specification:

Coefficients for Table 5, Panel D

\begin{tabular}{|c|c|c|c|c|c|c|}
\hline \multirow[t]{3}{*}{ Dependent variable: } & \multicolumn{2}{|c|}{ Enrollment ratio, } & \multicolumn{2}{|c|}{ Dropout, Ages 17-18 } & \multicolumn{2}{|c|}{$\begin{array}{c}\ln (\text { Expected Earnings) } \\
\text { Ages } 25+\end{array}$} \\
\hline & Male & Female & \multicolumn{2}{|c|}{ Male Female } & Male & Female \\
\hline & $(1)$ & $(2)$ & $(3)$ & $(4)$ & $(5)$ & $(6)$ \\
\hline & \multicolumn{6}{|c|}{ Value of reserves using 2003 prices (1000s of \$2012) } \\
\hline Shale reserves per capita & -0.0003 & -0.0002 & 0.0006 & -0.0002 & 0.0001 & 0.0000 \\
\hline x 2006-10 & $(0.0017)$ & $(0.0018)$ & $(0.0009)$ & $(0.0008)$ & $(0.0000)$ & $(0.0000)$ \\
\hline Shale reserves per capita & -0.0036 & 0.0009 & 0.0029 & 0.0004 & 0.0003 & 0.0001 \\
\hline x 2011-15 & $(0.0016)$ & $(0.0021)$ & $(0.0009)$ & $(0.0008)$ & $(0.0001)$ & $(0.0000)$ \\
\hline$p:=$ coefs (across yr. groups) & 0.06 & 0.40 & 0.01 & 0.49 & 0.00 & 0.00 \\
\hline \multirow[t]{2}{*}{ R-squared } & 0.764 & 0.776 & 0.539 & 0.493 & 0.938 & 0.955 \\
\hline & \multicolumn{6}{|c|}{ Value of reserves using 2012 prices (1000s of \$2012) } \\
\hline Shale reserves per capita & 0.0000 & 0.0003 & 0.0004 & 0.0001 & 0.0001 & 0.0000 \\
\hline x 2006-10 & $(0.0011)$ & $(0.0012)$ & $(0.0004)$ & $(0.0005)$ & $(0.0000)$ & $(0.0000)$ \\
\hline Shale reserves per capita & -0.0023 & 0.0008 & 0.0019 & 0.0006 & 0.0002 & 0.0000 \\
\hline x 2011-15 & $(0.0011)$ & $(0.0014)$ & $(0.0006)$ & $(0.0005)$ & $(0.0001)$ & $(0.0000)$ \\
\hline$p:=$ coefs (across yr. groups) & 0.05 & 0.56 & 0.01 & 0.37 & 0.00 & 0.01 \\
\hline \multirow[t]{2}{*}{ R-squared } & 0.764 & 0.776 & 0.538 & 0.493 & 0.937 & 0.955 \\
\hline & \multicolumn{6}{|c|}{ Simulated reserves in 2008 (1000s of MMBTUs) } \\
\hline Shale reserves per capita & 0.0395 & 0.0111 & 0.0034 & -0.0148 & 0.0020 & 0.0005 \\
\hline x 2006-10 & $(0.0353)$ & $(0.0506)$ & $(0.0251)$ & $(0.0181)$ & $(0.0008)$ & $(0.0004)$ \\
\hline Shale reserves per capita & -0.0605 & 0.0409 & 0.0536 & 0.0155 & 0.0064 & 0.0017 \\
\hline x 2011-15 & $(0.0543)$ & $(0.0570)$ & $(0.0251)$ & $(0.0202)$ & $(0.0020)$ & $(0.0008)$ \\
\hline$p:=$ coefs (across yr. groups) & 0.07 & 0.53 & 0.04 & 0.11 & 0.00 & 0.02 \\
\hline R-squared & 0.763 & 0.776 & 0.538 & 0.493 & 0.933 & 0.954 \\
\hline \multicolumn{7}{|c|}{$\begin{array}{l}\text { Notes: Underlying sample consists of the } 202 \mathrm{CZs} \text { in the } 14 \text { of the lower } 48 \text { states with any major shale gas or oil play ( } 17 \text { states), with available data from the } \\
\text { QWI for } 2000-2015 \text {, and between the } 5 \text { th and } 90 \text { th percentile of size (based on average population of } 17-18 \text {-year-olds over } 2000-2005) \text { for their state (202 of } \\
259 \text { CZs for each outcome except the enrollment-to-population ratio, where there are } 200 \text { CZs). The unit of observation is CZ-year-sex. Unless otherwise noted } \\
\text { (Panel B), all regressions include state-by-year and CZ fixed effects, as well as time-varying effectsd of each of the } 2000 \text { Census CZ characteristics listed in } \\
\text { Table } 1 \text { Panel D. Cell entries give estimated effects on outcomes as of } 2011-15 \text { for the average CZ in the estimation sample with any shale reserves, calculated } \\
\text { from model } 2 \text { as described in the text. Regressions for dropout rates (columns } 3 \text { and } 4 \text { ) are weighted by the number of Census or ACS respondents used to } \\
\text { generate the CZ-year-sex mean dropout rates. Standard errors (in parentheses) are clustered on CZ. }\end{array}$} \\
\hline
\end{tabular}


Appendix Table A7 -

Additional Specification Checks on Sample Selection Criteria

\begin{tabular}{|c|c|c|c|c|c|c|}
\hline \multirow[t]{3}{*}{ Dependent variable: } & \multicolumn{2}{|c|}{$\begin{array}{c}\text { Enrollment ratio, } \\
\text { Gr 11-12: Ages 17-18 }\end{array}$} & \multicolumn{2}{|c|}{ Dropout, Ages 17-18 } & \multicolumn{2}{|c|}{$\begin{array}{c}\ln \text { (Expected Earnings) } \\
\text { Ages } 25+ \\
\end{array}$} \\
\hline & Male & Female & Male & Female & Male & Female \\
\hline & $(1)$ & $(2)$ & $(3)$ & $(4)$ & $(5)$ & $(6)$ \\
\hline & \multicolumn{6}{|c|}{$\begin{array}{l}\text { Using all } 17 \text { States with Major Shale Plays } \\
\text { (Does Not Change Earnings Estimates Relative to Baseline) }\end{array}$} \\
\hline Average effect $2011-15$, reserves $>0$ & $\begin{array}{l}-1.25 \\
(0.58)\end{array}$ & $\begin{array}{c}0.34 \\
(0.78)\end{array}$ & $\begin{array}{l}0.98 \\
(0.31)\end{array}$ & $\begin{array}{l}0.04 \\
(0.33)\end{array}$ & $\begin{array}{l}0.104 \\
(0.027)\end{array}$ & $\begin{array}{c}0.026 \\
(0.010)\end{array}$ \\
\hline $\begin{array}{l}\text { Shale reserves per capita } \\
\qquad \times \text { 2006-10 }\end{array}$ & $\begin{array}{l}-0.0017 \\
(0.0151)\end{array}$ & $\begin{array}{l}-0.0014 \\
(0.0159)\end{array}$ & $\begin{array}{c}0.0038 \\
(0.0080)\end{array}$ & $\begin{array}{l}-0.0053 \\
(0.0075)\end{array}$ & $\begin{array}{c}0.0007 \\
(0.0002)\end{array}$ & $\begin{array}{c}0.0001 \\
(0.0001)\end{array}$ \\
\hline $\begin{array}{l}\text { Shale reserves per capita } \\
\qquad \text { x 2011-15 }\end{array}$ & $\begin{array}{l}-0.0320 \\
(0.0150)\end{array}$ & $\begin{array}{c}0.0087 \\
(0.0200)\end{array}$ & $\begin{array}{c}0.0252 \\
(0.0080)\end{array}$ & $\begin{array}{c}0.0010 \\
(0.0084)\end{array}$ & $\begin{array}{c}0.0025 \\
(0.0006)\end{array}$ & $\begin{array}{c}0.0006 \\
(0.0002)\end{array}$ \\
\hline$p:=$ coefs (across yr. groups) & 0.06 & 0.43 & 0.00 & 0.44 & 0.00 & 0.00 \\
\hline$p:=$ coefs. $($ across sex, $2011-15)$ & \multicolumn{2}{|c|}{0.13} & \multicolumn{2}{|c|}{0.03} & \multicolumn{2}{|c|}{0.000} \\
\hline \multirow[t]{2}{*}{ R-squared } & 0.761 & 0.778 & 0.524 & 0.479 & 0.936 & 0.954 \\
\hline & \multicolumn{6}{|c|}{ Dropping Smallest \& Largest $10 \%$ of CZs in State } \\
\hline Average effect $2011-15$, reserves $>0$ & $\begin{array}{l}-1.65 \\
(0.56)\end{array}$ & $\begin{array}{l}0.30 \\
(0.82)\end{array}$ & $\begin{array}{c}0.98 \\
(0.40)\end{array}$ & $\begin{array}{c}0.22 \\
(0.31)\end{array}$ & $\begin{array}{c}0.108 \\
(0.026)\end{array}$ & $\begin{array}{l}0.026 \\
(0.010)\end{array}$ \\
\hline Shale reserves per capita & -0.0044 & -0.0071 & 0.0012 & 0.0019 & 0.0007 & 0.0001 \\
\hline x 2006-10 & $(0.0158)$ & $(0.0162)$ & $(0.0088)$ & $(0.0072)$ & $(0.0002)$ & $(0.0001)$ \\
\hline $\begin{array}{l}\text { Shale reserves per capita } \\
\qquad \times \text { 2011-15 }\end{array}$ & $\begin{array}{l}-0.0388 \\
(0.0131)\end{array}$ & $\begin{array}{c}0.0070 \\
(0.0192)\end{array}$ & $\begin{array}{c}0.0229 \\
(0.0094)\end{array}$ & $\begin{array}{c}0.0052 \\
(0.0072)\end{array}$ & $\begin{array}{c}0.0025 \\
(0.0006)\end{array}$ & $\begin{array}{c}0.0006 \\
(0.0002)\end{array}$ \\
\hline$p:=$ coefs (across yr. groups) & 0.05 & 0.20 & 0.00 & 0.66 & 0.000 & 0.001 \\
\hline$p:=$ coefs. $($ across sex, $2011-15)$ & \multicolumn{2}{|c|}{0.07} & \multicolumn{2}{|c|}{0.12} & \multicolumn{2}{|c|}{0.000} \\
\hline \multirow[t]{2}{*}{ R-squared } & 0.794 & 0.802 & 0.545 & 0.503 & 0.942 & 0.957 \\
\hline & \multicolumn{6}{|c|}{ Dropping Smallest \& Largest $5 \%$ of CZs in State } \\
\hline Average effect $2011-15$, reserves $>0$ & $\begin{array}{l}-1.39 \\
(0.59)\end{array}$ & $\begin{array}{c}0.30 \\
(0.78)\end{array}$ & $\begin{array}{c}0.79 \\
(0.38)\end{array}$ & $\begin{array}{c}0.47 \\
(0.32)\end{array}$ & $\begin{array}{c}0.105 \\
(0.026)\end{array}$ & $\begin{array}{c}0.026 \\
(0.010)\end{array}$ \\
\hline Shale reserves per capita & -0.0027 & -0.0009 & -0.0020 & -0.0028 & 0.0007 & 0.0001 \\
\hline x 2006-10 & $(0.0158)$ & $(0.0157)$ & $(0.0082)$ & $(0.0066)$ & $(0.0002)$ & $(0.0001)$ \\
\hline Shale reserves per capita & -0.0342 & 0.0073 & 0.0194 & 0.0116 & 0.0026 & 0.0006 \\
\hline x 2011-15 & $(0.0145)$ & $(0.0191)$ & $(0.0093)$ & $(0.0079)$ & $(0.0006)$ & $(0.0002)$ \\
\hline$p:=$ coefs (across yr. groups) & 0.05 & 0.52 & 0.00 & 0.09 & 0.000 & 0.001 \\
\hline$p:=$ coefs. $($ across sex, $2011-15)$ & \multicolumn{2}{|c|}{0.11} & \multicolumn{2}{|c|}{0.49} & \multicolumn{2}{|c|}{0.000} \\
\hline R-squared & 0.770 & 0.783 & 0.561 & 0.510 & 0.941 & 0.959 \\
\hline $\begin{array}{l}\text { Notes: Baseline sample consists of the } 202 \mathrm{CZs} \text { in the } 1 \\
\text { QWI for } 2000-2015 \text {, and between the } 5 \text { th and } 90 \text { th perc } \\
259 \mathrm{CZs} \text { for each outcome except the enrollment-to-pop } \\
\text { states with major shale plays but without QWI data for } 2 \\
\text { sample ( } 186 \mathrm{CZs} \text { ), and trimming the top and bottom } 5 \% \\
\text { sex. All regressions include state-by-year and CZ fixed } \\
\text { Panel D. Regressions for dropout rates (columns } 3 \text { and }\end{array}$ & $\begin{array}{l}4 \text { of the lower } \\
\text { ntile of size } \\
\text { lation ratio, }\end{array}$ & $\begin{array}{l}\text { tates with an } \\
\text { d on average } \\
\text { e there are } 20 \\
\text { mming the to }\end{array}$ & $\begin{array}{l}\text { or shale gas or } \\
\text { ation of } 17-18 \\
\text { ). Panels cha } \\
\text { bottom } 10 \% \\
\text { al } 14 \text {-state sa }\end{array}$ & $\begin{array}{l}\text { play }(17 \text { state } \\
\text { r-olds over } 20 \\
\text { this estimatio } \\
\text { Zs within each } \\
(214 \mathrm{CZs}) \text {. T } \\
000 \text { Census } \\
\text { ndents used tc }\end{array}$ & $\begin{array}{l}\text { havailable da } \\
05 \text { ) for their s } \\
\text { ple in various } \\
\text { in the origina } \\
\text { it of observat } \\
\text { racteristics li } \\
\text { rate the CZ-y }\end{array}$ & $\begin{array}{l}\text { om the } \\
\text { (202 of } \\
\text { (s), adding3 } \\
\text {-state } \\
\text { is CZ-year- } \\
\text { in Table 1 } \\
\text { sex mean }\end{array}$ \\
\hline
\end{tabular}

